UNIVERSIDADE DE SÃO PAULO

FACULDADE DE FILOSOFIA, LETRAS E CIÊNCIAS HUMANAS

DEPARTAMENTO DE LETRAS CLÁSSICAS E VERNÁCULAS

PROGRAMA DE PÓS-GRADUAÇÃO EM ESTUDOS COMPARADOS

DE LITERATURAS DE LÍNGUA PORTUGUESA

ALEXANDRE GOMES NEVES

NARRATIVAS DE RUY DUARTE DE CARVALHO

São Paulo

2015 
FACULDADE DE FILOSOFIA, LETRAS E CIÊNCIAS HUMANAS

DEPARTAMENTO DE LETRAS CLÁSSICAS E VERNÁCULAS

PROGRAMA DE PÓS-GRADUAÇÃO EM ESTUDOS COMPARADOS

DE LITERATURAS DE LÍNGUA PORTUGUESA

\section{NARRATIVAS DE RUY DUARTE DE CARVALHO}

Alexandre Gomes Neves

Tese apresentada ao Programa de Pós-Graduação em Estudos Comparados de Literaturas de Língua Portuguesa do Departamento de Letras Clásicas e Vernáculas da Faculdade de Filosofia, Letras e Ciências Humanas da Universidade de São Paulo, para obtenção do título de Doutor em Letras

Orientadora: Profa. Dra. Rita de Cássia Natal Chaves

São Paulo 


\section{AGRADECIMENTOS}

À CAPES - Coordenação de Aperfeiçoamento de Pessoal de Nível Superior, pela bolsa concedida.

À Rita Chaves.

À Laura Padilha e ao Vagner Gonçalves Silva.

À Camila Zanon e ao Antonio Pereira.

A todos que direta ou indiretamente contribuíram para que o trabalho se tornasse possível. 


\section{RESUMO}

Neves, Alexandre Gomes. Narrativas de Ruy Duarte de Carvalho. 2014. Tese (Doutorado). Faculdade de Filosofia, Letras e Ciências Humanas. Universidade de São Paulo, São Paulo, 2014.

Realizamos, nesse trabalho, uma leitura crítica de um conjunto de obras narrativas do escritor e antropólogo Ruy Duarte de Carvalho. A abordagem está centrada em sua trilogia, intitulada "Os filhos de Próspero", composta pelos seguintes títulos: Os papéis do inglês (2000), As paisagens propícias (2005) e A terceira metade (2009). Incluímos comentários acerca das seguintes obras: Como se o mundo não tivesse leste (1977), Vou lá visitar pastores (1999) e Desmedida: Luanda-São Paulo-São Francisco e volta Crônicas do Brasil (2006). Inicialmente, nos aproximamos do trabalho do antropólogo a partir de sua relação com o cinema o que nos levou à leitura de $O$ camarada e câmera: cinema e antropologia para além do filme etnográfico (1984). Na sequência propomos um mergulho em sua trilogia focalizando a construção das identidades em Angola. A partir da análise de personagens centrais, nomeadamente Severo de As paisagens propícias e Trindade de A terceira metade, pretendemos contribuir com uma interpretação que leve em conta a temática das relações entre escrita e oralidade.

Palavras-chave: identidade, narrativa, viagem, escrita, oralidade, Ruy Duarte de Carvalho. 


\begin{abstract}
Neves, Alexandre Gomes. Ruy Duarte de Carvalho's Narratives. Tese (Doutorado). Faculdade de Filosofia, Letras e Ciências Humanas. Universidade de São Paulo, São Paulo, 2014.

In this thesis we have produced a critical reading of a set of narrative works by the writer and anthropologist Ruy Duarte de Carvalho. The approach is focused on his trilogy entitled Os filhos de Próspero, composed by the following books: Os papéis do inglês (2000), As paisagens propícias (2005) and A terceira metade (2009). Remarks have been added about the following works: Como se o mundo não tivesse leste (1977), Vou lá visitar pastores (1999) e Desmedida: Luanda-São Paulo-São Francisco e voltaCrônicas do Brasil (2006). Initially, we approached the anthropologist's work regarding its relation to the cinema, what led us to read $O$ camarada e câmera: cinema $e$ antropologia para além do filme etnográfico (1984). Then, we proposed a dive into his trilogy focusing the building of identities in Angola. Based on the analysis of the central characters, namely Severo, from As paisagens propícias, and Trindade, from A terceira metade, we intend to offer an interpretation that takes into consideration the theme concerning the relations between writing and orality.
\end{abstract}

Keywords: identity, narrative, traveling, writing, orality, Ruy Duarte de Carvalho. 


\section{SUMÁRIO}

Introdução.............................................................8

\section{Capítulo 1}

A poética do olhar antropológico..................17

"Cinema e antropologia"............................19

"Para além do filme etnográfico"...............25

"O caso em situação".......................................36

\section{Capítulo 2}

Viagens em textos.........................................47

Os papeis do inglês:

Ode à viagem dos descomportados .51

As paisagens propícias:

Diálogos com o passado

A terceira metade:

Viagem ao humano .80

\section{Capítulo3}

A permanência da poesia...............................99

Poesia em Os papeis do inglês.......................116

Vou lá visitar pastores:

subjetividade e objetividade.

Conclusões.

Bibliografia. .136 


\section{Introdução}

Ruy Duarte de Carvalho, escritor bastante respeitado e admirado, deixa-nos um legado que constitui um desafio para as leituras críticas construídas em torno de sua obra. Costumamos nos surpreender com uma produção ou um texto que, ao ultrapassar limites relacionados ao contexto de sua produção, torna-se referência para pesquisadores de áreas distintas e para a média dos leitores. Nestes termos, vale a lembrança de Os Sertões, de Euclydes da Cunha. Caso emblemático na literatura e na história do pensamento intelectual no Brasil.

Carvalho, nascido em 1941, Santarém (Portugal), faleceu na Namíbia em agosto de 2010. Teve inúmeras atividades como intelectual, foi antropólogo, poeta, ficcionista e cineasta. De sua produção destacamos Lavra, livro que reúne a produção poética do autor de 1970 a 2000; Os papeis do inglês (2000), livro em que inaugura sua incursão no gênero romance, Desmedida: Luanda-São Paulo- São Francisco e volta. Crônicas do Brasil (2006), em que o autor confirma seu interesse pelo Brasil (territórios e paisagens literárias) ao relatar uma viagem pelo São Francisco e seus diálogos com a produção textual de importantes autores brasileiros, como Euclydes da Cunha e Guimarães Rosa. Temos também As paisagens propícias (2005) e A terceira metade (2009), livros que com Os papeis do inglês formam a trilogia Os filhos de Próspero. Nesta trilogia, Ruy Duarte colocará sob foco, dentre outras questões, o que poderíamos chamar de a problemática da produção da existência a partir das configurações das identidades. Como se o mundo não tivesse leste (1977) é um livro de estórias que nos surpreende pela poesia que emerge da prosa. Não poderíamos deixar de mencionar Vou lá visitar pastores (1999), obra que registra seu trabalho como antropólogo e escritor junto aos Kuvale, população Herero do sul de Angola. 
A obra narrativa de Carvalho (não só, pois poderíamos nos referir à sua poesia) em vários aspectos constitui uma extensão das preocupações do antropólogo. Seus textos, tecidos na fronteira de diferentes gêneros, tensionados entre a ficção, a poesia e o ensaio etnográfico, nos propõem a reflexão sobre esses novos tempos em que os antropólogos, muitas vezes, assumem a natureza subjetiva e marcadamente autoral das narrativas que constroem. Livros como Vou lá visitar pastores, Os papeis do inglês e As paisagens propícias desafiam a divisão dos gêneros e a recepção dos leitores. (CHAVES, 2007, p.135) Ainda que só o primeiro possa ser recepcionado como uma etnografia, por apresentar os Kuvale, povo pastoril do sul de Angola, constituindo os outros dois romances, em todos eles registra-se a viagem iniciática que fará o sujeito viajante voltar-se para si ao dialogar com paisagens e sujeitos distintos, ao entrar em contato com a alteridade. Podemos dizer que, independentemente do gênero em que se realiza a escrita de Carvalho, há sempre uma reflexão sobre o olhar para o outro. Todos os seus livros são marcados pelo que podemos chamar, nos termos de James Clifford, pela experiência etnográfica ou o "estar lá” na formulação não ortodoxa, mas absolutamente expressiva de Clifford Geertz. Ainda que as descrições não possam ser mais totalizantes, pois se vive uma crise na capacidade explicativa das ciências humanas, continua presente no horizonte do etnógrafo o método da observação participante de Malinowski. Se muitos sistemas explicativos das ciências sociais envelheceram, não envelheceu o trabalho de campo como um intenso envolvimento intersubjetivo capaz de produzir novos conhecimentos. (CLIFFORD, 2002, p. 20) E a escrita etnográfica passou a percorrer novos caminhos, aproximando-se bem mais da arte e de outras ciências humanas.

Devemos considerar que, em suas viagens para redescobrir seu país, Ruy Duarte movimenta uma gama de temas recorrentes na literatura angolana, o que nos permite 
apreciar a elevada consciência que possui de sua tradição literária. Autores como Assis Jr., Castro Soromenho e Oscar Ribas, frequentemente têm suas obras analisadas como documentário das sociedades por eles observadas. Talvez não seja demasiado sugerir com Diego Marques (2007) que a relação entre literatura e investigações de cunho etnográfico poderá ser apreciada como uma marca na literatura angolana, constituindo uma de suas linhas de força. Temos nos autores citados, exemplos de escritas empenhadas na observação e na descrição de sistemas culturais pertencentes a uma ordem diversa da do escritor e da do leitor. Escritas que, não raro, executam uma mediação entre sujeitos distintos, o que nos força a lembrar do trabalho do etnógrafo, também mediador, leitor e tradutor de culturas. Em $O$ segredo da morta, por exemplo, é o próprio autor, Assis Jr., quem nos propõe que seu texto está voltado para revelar a vida da terra, para divulgar os costumes ainda não obliterados pela imposição da cultura do colonizador. Rita Chaves em A formação do romance angolano (1999) demonstra o quanto o tratamento da morte no romance de Assis Jr. pode ser mais bem compreendido quando o leitor serve-se do auxílio de trabalhos antropológicos que decifram os rituais ligados à morte em sociedades africanas. Em relação a Castro Soromenho, podemos destacar as suas andanças pelo interior de Angola a serviço do governo português. Tais viagens lhe proporcionaram o contato direto com diversas culturas e com os choques causados pelo colonialismo, experiência esta que, marcará as páginas de sua literatura. (HAMILTON, 1975, p.60) Sobre este autor escreveu Chaves no trabalho já citado: "Há um primeiro momento na história de sua obra que a perspectiva do etnólogo se faz preponderante, e o resultado é um conjunto de textos que, tangenciando as fronteiras do literário, têm sido preferencialmente abordados como documentos (...)" (CHAVES, 1999, p. 99) Quanto a Oscar Ribas, procuramos demonstrar em nossa dissertação de mestrado, Câmara Cascudo e Oscar Ribas: diálogos no Atlântico (FFLCH, USP, 2008) 
que, sua principal obra ficcional, o romance Uanga (feitiço) (1951), deve ser compreendido nos limites da ação do pesquisador em folclore, pois prepondera no texto o compromisso com a sistematização e divulgação de dados coletados pelo autor. Ainda que os autores citados não sejam antropólogos de formação, suas escritas nos encaminham para a reflexão sobre o encontro entre culturas e não será demasiado lembrar que este encontro se dá no contexto colonial. Ruy Duarte, antropólogo de formação, poderá ser considerado a alta expressão de um conjunto de autores cujas produções tangenciam diferentes instâncias discursivas, pois caminham entre a literatura e outras formas de conhecimento e de produção do discurso.

Realizamos, nesse trabalho, uma leitura crítica de um conjunto de obras narrativas do autor. A abordagem está centrada em sua trilogia, intitulada Os filhos de Próspero, composta, como já indicamos, pelos seguintes títulos: Os papeis do inglês (2000), As paisagens propícias (2005) e A terceira metade (2009). Incluímos comentários acerca das seguintes obras: Como se o mundo não tivesse leste (1977), Vou lá visitar pastores (1999) e Desmedida: Luanda-São Paulo-São Francisco e volta. Crônicas do Brasil (2006). Inicialmente, nos aproximamos do trabalho do antropólogo a partir de sua relação com o cinema o que nos levou à leitura de $O$ camarada e a câmera: cinema e antropologia para além do filme etnográfico (1984).

Uma análise das leituras críticas que focalizam a literatura de Ruy Duarte de Carvalho nos permite produzir algumas inferências. Considerando que toda tentativa de sistematização ou de produção de esquemas abrangentes possui falhas, já que a realidade sempre nos confronta com exemplos que fogem da ordenação imposta pelo esquema, o que fazemos é não mais do que indicar módulos a partir dos quais a produção intelectual do antropólogo e escritor angolano vem sem sendo apreendida nos ensaios, teses e dissertações disponíveis. 
Em nossa bibliografia tentamos reunir um pequeno corpus de trabalhos empenhados em entender e nos introduzir nos caminhos da prosa ensaística de Carvalho. Esse pequeno corpus é o resultado atual a que tivemos acesso de investigações realizadas por professores, pesquisadores e estudantes.

Interessa-nos destacar que os trabalhos produzidos garantem uma boa possibilidade de visão de conjunto. Consideramos que eles nos indicam, no mínimo, três vertentes de enquadramento crítico: as abordagens que ressaltam o espaço como categoria analítica fundamental, aquelas que se dedicam a problemática que as obras de Carvalho geram para o entendimento do foco narrativo, e as abordagens que têm no imbricamento visto entre literatura e antropologia o foco da análise.

Quando o espaço é ponto de vista fundamental do leitor crítico, vemos que os textos focalizam conceitos como: espaço, paisagem, território, geografia, deslocamento e viagem. Neste caso, podemos tomar como referencial os trabalhos de Rita Chaves. São vários os textos em que a ensaísta percorre a temática do espaço e da viagem como essenciais para a compreensão da poética de Ruy Duarte de Carvalho.

Nas abordagens que focalizam o foco narrativo vemos que a crítica percorre questões relativas à noção de autoria. As investigações tentam apreender os sentidos criados nos textos de Carvalho a partir da constatação de que as vozes dos narradores se confundem com a voz do autor real na medida em que as referências extratextuais podem ser aferidas. Nesse sentido, podemos citar o ensaio de Sandro Ornellas, "Ruy Duarte de Carvalho em transumância pelos discursos", que considera que o processo de ficção de si constitui o exercício ético do autor, pois representa novas posturas antropológicas nas quais os pesquisadores se questionam a si próprios tanto quanto os 
universos pesquisados (ORNELLAS, 2009). Consideramos de grande auxílio retomar Ana Mafalda Leite, quando aborda a obra poética de Ruy Duarte de Carvalho.

Reparamos que em todos os seus livros existe uma reflexão poetizada dos trajectos em que se demarca a escrita. Esta contínua anotação em abismo mostra que o próprio processo criativo se interroga ao mesmo tempo que se produz, que a poesia nasce também de um distanciamento de si própria, como que autogerando-se na pesquisa de sua existência, levando a que, em simultâneo, o sujeito nela implicado sofra idêntico processo. (LEITE, 1998, p. 133)

Suas avaliações podem ser estendidas à produção narrativa do autor, ainda que tenham sido produzidas em relação à poesia e antes de Carvalho trazer à tona sua obra narrativa, excetuando-se as estórias de Como se o mundo não tivesse leste (1977). A metalinguagem conforma o seu fazer literário. Em todos os livros encontramos a voz do autor refletindo sobre os conteúdos pelos quais se interessa e ao mesmo tempo em busca da forma adequada para dizer o que quer e necessita, daí uma continuada variação dos gêneros empregados. Tal variação representa a busca pela forma adequada para as matérias que movimenta em sua obra.

Na terceira abordagem estão trabalhos que focalizam o que, talvez, possamos chamar de relações entre literatura e antropologia. A esse grupo poderíamos associar tanto os trabalhos que tomam como ponto de partida a proposição de que os textos de Ruy Duarte de Carvalho podem ser inseridos numa prática e numa reflexão pautada pela ideia de "descolonização dos saberes" quanto aqueles voltados para as questões relativas ao tratamento dado pelos escritores às tradições orais.

No primeiro caso, a dissertação de mestrado de Diego Ferreira Marques (2007) nos oferece uma excelente oportunidade de reflexão. No segundo caso, apontamos para a importância de um texto de Laura Cavalcante Padilha. "Reconversões", de Padilha, publicado no primeiro número da revista Via Atlântica, em 1997, formula comparações 
entre os poetas Ruy Duarte e o brasileiro Edimilson de Almeida Pereira. Ambos partem da palavra e do imaginário apreendidos na relação com as tradições orais de seus países para a composição de suas vozes poéticas. Segundo Padilha, os poetas "propondo suas reconversões literárias, tentam reencenar a experiência anterior do homem africano, retecendo, pela linguagem, seus valores, sua fé, sua diferença, enfim.” (PADILHA, 1997, p. 145)

Devemos salientar que essa tentativa de sistematização das análises críticas que passaram a constituir nosso repertório, além de estarem longe de esgotar o que já foi produzido em relação ao autor, não deverão ser lidas como encaixadas nos tópicos propostos. A complexidade da produção de Ruy Duarte por si só acaba obrigando que as leituras críticas percorram os diferentes temas e as diferentes questões abrigadas nas obras.

Além disso, há que se considerar que o tema da identidade ou identidades atravessa os vários conjuntos de trabalhos. Uma busca constante do pensamento de Ruy Duarte foi pela compreensão dos processos pelos quais as identidades em Angola e, por extensão, no continente africano, podem ser pensadas tendo em vista os processos pelos quais elas são elaboradas e reelaboradas. Assim sendo, refletir sobre a prosa e a poesia desse autor tem sido um modo de compreender o que ele tem a nos ensinar sobre essas identidades. Esse pressuposto nos faz por em destaque Archibad Perkings, Severo e Jonas Trindade, personagens que habitam respectivamente Os papeis do inglês, As paisagens propícias e A terceira metade.

No primeiro capítulo, intitulado "A poética do olhar antropológico", retomamos as reflexões do autor em torno do cinema e da sua utilização pela antropologia a partir de uma leitura de $O$ camarada e a câmera - cinema e antropologia para além do filme 
etnográfico, publicado em 1984. O exame dessa obra nos permite compreender a importância do cinema em sua investigação antropológica, estética e ética. Essas três dimensões estão absolutamente aglutinadas no trabalho do intelectual ao longo de sua trajetória. O livro citado e, particularmente, sua terceira parte, "O caso em situação", nos permite acompanhar os processos de imbricamento entre projeto estético e projeto de pesquisa. E ao mesmo tempo vislumbrar como o exercício da ética se realiza concretamente a partir das relações reais impostas pelo terreno em que o trabalho se desenvolve. O capítulo também nos permite acompanhar as escolhas e algumas reflexões do autor em relação ao tratamento das formas orais. Nesse ponto encontramos a sugestão analítica e interpretativa de que Ruy Duarte opta pelo diálogo simultâneo com escritas e oralidades pertencentes ao contexto sociocultural em que mergulha.

No segundo capítulo, "Viagens em textos", procuramos compreender os romances e as personagens que os protagoniza tomando como elemento fundamental a intertextualidade instaurada em cada livro a partir do uso da citação de obras e autores. Em cada romance Carvalho convoca uma plêiade de autores e obras para compor o seu discurso. Consideramos que compreender os caminhos de sua prosa e de seu pensamento exige do leitor a recuperação dessas referências trazidas pelo autor, no sentido de lê-las com ele ou a partir dele, ou seja, aceitar o seu permanente convite à leitura. Suas citações criam simbolizações ou representações a serem lidas ou decifradas no interior de cada texto. A partir da referência a Michel Leiris queremos sugerir que o projeto estético de Ruy Duarte também esteve pautado pela representação da subjetividade mediada pela memória de seu repertório cultural e pela viagem que ao gerar o deslocamento gera experiência e processo de formação de uma consciência.

Outro escritor fundamental ao qual recorremos nesse capítulo é Guimarães Rosa. Veremos como a prosa fulgurante de Rosa foi transformada em inspiração para que 
Carvalho compusesse a sua particular trajetória na busca dos entrosamentos entre escrita e oralidade. Essa busca que tem seus inícios entre a poesia e as produções cinematográficas atravessou a sua produção em prosa e encontrou uma bela formulação em seus dois últimos romances, As paisagens propícias e A terceira metade.

O terceiro capítulo, "A permanência da poesia", constitui uma continuidade do anterior na medida em que buscamos compreender a permanência da poesia na prosa do autor e a partir disso propor a constatação da relevância de Como se o mundo não tivesse leste, particularmente a estória "João Carlos, natural do Chinguar, no Bié", na construção dessa busca pela voz poética. Além disso, realizamos alguns comentários em torno da obra Vou lá visitar pastores (1999) que, de um certo modo, nos remetem novamente ao primeiro capítulo e às considerações acerca das relações e das tensões geradas por projetos configurados na fronteira entre diferentes saberes, diferentes gêneros narrativos, diferentes práticas discursivas. 


\section{Capítulo 1}

\section{A poética do olhar antropológico}

Nenhum autor, ao pretender abordar num texto as questões que o preocupam, pode furtar-se a constatação de que o texto é o lugar de convergência de todos os dados que o informam e de que ele é, enquanto autor, o lugar do próprio texto. Texto e autor, assim, fazem parte do corpo de elementos que determinam o tratamento das questões propostas. Daqui resulta uma subjectividade evidente (e inalienável) que mais vale assumir e utilizar, fazendo apelo a um máximo de conhecimentos e, sobretudo, de experiências ${ }^{1}$.

Ruy Duarte de Carvalho

Viajar é, certamente, um verbo imprescindível ao elaborarmos qualquer comentário acerca de Ruy Duarte de Carvalho. Viagens e deslocamentos que comportam permanências. Fixidez e mobilidade configuram no autor um quadro de tensões cujo equilíbrio é conquistado por uma escrita de variadas feições.

Dois sentidos se entrelaçam ao percorrermos os textos do autor: o acompanhamos para ver sujeitos, paisagens e territórios, e o nosso olhar aprende a seguir os contornos das geografias que frequenta; e, num sentido verticalizado, nos aprofundamos nas viagens dos textos trazidos pelo autor. Ao lermos Carvalho, lemos com ele o universo de referências textuais que o formam. O que nos faz contemplar uma escrita de generosidade plena e rigor incontestável.

Vemos, exemplarmente representada, na trajetória de Ruy Duarte de Carvalho, a síntese dos narradores primordiais de Walter Benjamin. O marinheiro e o agricultor fundem-se num percurso cumprido com fidelidade a si mesmo. $\mathrm{O}$ viajante, metaforizado pela imagem do marinheiro é portador do conhecimento de outras terras, de outras culturas. Ruy Duarte, poeta e antropólogo, viaja pela sua terra na maior parte de seus escritos e nos mostra gestos, dinâmicas e identidades surpreendentes para ele próprio.

\footnotetext{
${ }^{1}$ A epígrafe que utilizamos pode ser lida sob o título de "Advertência" em O camarada e a câmera: cinema e antropologia para além do filme etnográfico (1984), de Ruy Duarte de Carvalho.
} 
Seu interesse voltou-se sobretudo para os povos do sul de Angola, o poeta foi aos poucos acumulando saberes e experiências desse espaço eleito por afinidades e como um agricultor, passou a cultivar variações no interior e a partir desse chão.

Nas palavras do antropólogo Luís Quintais,

O que o Ruy tem feito é tão-só uma aventura projectiva que visa roubar à morte aquilo que parece constituir propriedade da morte: rostos, práticas, paisagens, modos de entender $\mathrm{o}$ mundo, que por maior que sejam as dinâmicas de reapropriação e reconstituição criativa, se afiguram condenados ao crepúsculo e à elegia. E daí não virá talvez problema de maior, quanto mais não seja porque o Ruy sabe que tudo é perda e o que interessa é a procura, a viagem, o jogo e, com toda a probabilidade, a ironia e a coragem com que se enfrenta o crepúsculo ou fim. Assim são à superfície suas histórias. Mas num plano mais profundo o que lhe interessa afinal é a busca de si mesmo. (QUINTAIS, 2006, p. 17)

A escrita de Carvalho, ao possuir variadas feições, deseja tornar disponível ao leitor que o acompanha tudo quanto fez parte de seu entorno, tudo quanto ao ser depurado por sua consciência pode comunicar as suas trajetórias, as suas experiências, os seus espaços de circulação, tudo aquilo que lhe possibilitou traçar tentativas de compreensão e formas de atuação no universo que foi o seu. Ao escrever sobre as matérias que lhe interessaram nunca deixou de, assumidamente, nelas projetar-se numa constante busca e análise do sujeito que se dedica ao conhecimento.

Nosso trabalho, que desde o projeto inicial, pretendia-se como uma investigação das relações entre literatura e antropologia em Ruy Duarte de Carvalho, tendo como foco a sua produção narrativa, não pode abster-se de uma aproximação, ainda que falha e não conclusiva, da face cineasta do intelectual. Podemos caracterizar a aproximação nestes termos, pois não realizaremos análises de filmes nem procuraremos entender a constituição desta arte sobre solo angolano. Estaremos restritos ao que nos afigura ser uma obra bastante significativa: O camarada e a câmera - cinema e antropologia para além do filme etnográfico (1984). Chegamos ao entendimento de que recuperar suas reflexões em torno do cinema ou, mais particularmente, em torno do filme etnográfico e para além dele, é um bom modo, se não for o melhor, de compreendermos os caminhos que sua narrativa trilhou. Ao efetuarmos a leitura detalhada do texto oferecido por Carvalho na obra citada iremos também recorrer a pesquisadores e trabalhos que possam nos auxiliar nessa tarefa. 
Seria insuficiente apenas mencionar que o nosso autor foi também cineasta, sem tentar esclarecer o significado do cinema para sua formação e sem verificar de que modo se deu esse entrelaçamento entre cinema e antropologia em seu percurso. Pensamos que isto é esclarecedor para o caminho que escolhemos percorrer. Já contamos com alguns trabalhos que abordam a obra de Ruy Duarte e não ignoram as relações entre literatura e antropologia, no entanto, faz-se necessária uma contribuição que, ao identificar as questões propriamente antropológicas que nortearam o seu trabalho, não ignore a importância do cinema para as suas reflexões sobre possíveis imbricações entre arte e ciência. De modo que consideramos de extrema pertinência o texto do qual nos aproximaremos a seguir e na medida atinente às nossas preocupações.

O camarada e a câmera - cinema e antropologia para além do filme etnográfico apresenta uma divisão em três partes, além da introdução e conclusão: no item I temos "Cinema e antropologia", em que somos apresentados ao teor mais substantivo do tema; no II temos "Para além do filme etnográfico", em que o autor discute práticas antropológicas para além da produção de filmes; e no item III temos "O caso em situação", em que o autor nos situa diante de sua experiência na produção e filmagens de Nelisita.

\section{"Cinema e antropologia"}

Na primeira parte, "Cinema e antropologia", podemos acompanhar um tópico inicial em que Ruy Duarte, a partir da bibliografia a que teve acesso, discute a problemática nada recente que envolve a produção de filmes no campo da antropologia. Conforme pondera, um dos nós é, justamente, a conciliação entre arte e ciência. (CARVALHO, 1984, p. 32) Como realizar um trabalho que, sendo responsável em relação aos conteúdos de uma disciplina científica, seja também um bom filme, um produto esteticamente desejável? O autor admite a possibilidade de um antropólogo fazer uso de filmagens apenas como "instrumento de investigação e um meio para a exposição dos resultados do seu trabalho". (CARVALHO, 1984, p. 32) Porém, neste caso, o antropólogo só será interpelado enquanto antropólogo, não se poderá cobrar dele a produção de um cineasta. Servir-se da câmera para produção de registros não é, necessariamente, produzir um filme. O que de imediato nos permite entender que o cerne da problemática está em se querer fazer cinema e antropologia, e não utilizar-se 
de filmagens como um apêndice ou mais um recurso entre outros. Contudo, enfatizemos que o qualificativo "etnográfico", não deveria tornar um filme menos filme nas ponderações de Ruy Duarte.

Há uma retomada de tipologias propostas por Claudine de France (1982) e D. Macdougall (1978). Tomamos a liberdade de deixar de lado a resenha que o autor faz dessas propostas para destacarmos um ponto chave de nosso trabalho que é esta relação entre instâncias discursivas, não raro, postas em oposição: a subjetividade que marca a produção artística e a objetividade requerida pela produção científica. Conciliá-las, cabe frisar, tem sido o objetivo daqueles que veem no cinema empregado na antropologia, mais que uma forma de registro documental, e sim um caminho para a descoberta de respostas e perguntas novas. A produção visual pode ser utilizada como metodologia de uma pesquisa, mas, além disso, constitui um campo aberto para novas questões teóricas e metodológicas surgidas a partir dos usos que os pesquisadores fazem dos recursos tecnológicos disponíveis.

Em relação ao último ponto, pode ser útil nos valermos da citação de um trabalho interessante e relativamente recente do antropólogo e cineasta brasileiro (ou cineasta com formação em antropologia) Kiko Goifman. Valetes em slow motion: a morte do tempo na prisão (1998) é o resultado de pesquisa realizada com população carcerária de três presídios (dois localizados em São Paulo e um em Minas Gerais) e com o objetivo de entender as negociações estabelecidas a partir da relação com o tempo, já que esta categoria saltou aos olhos do pesquisador desde os inícios do trabalho. Num mundo que pode ser percebido e descrito como acelerado e volátil chamam a atenção a ociosidade e a disponibilidade de tempo dos encarcerados. (GOIFMAN, 1998, p.24)

A captação de sons e imagens, segundo Goifman, foi fundamental para a pesquisa. O registro sonoro possibilitou uma análise mais detalhada das falas, não só em relação aos usos vocabulares e aos conteúdos, como também pôde observar variações rítmicas, entonações, pausas, duração dos discursos, etc. Com relação à captação de imagens, o pesquisador ressalta a importância do vídeo por possibilitar a observação repetida e diferenciada, pois o vídeo alarga a experiência obtida no trabalho de campo. O vídeo torna disponíveis no momento de escrita do texto, os discursos, gestos e outros elementos filmados. (GOIFMAN, 1998, p.28). Devemos ainda mencionar que a 
captação de imagens atuou sobre a sensibilidade do pesquisador fazendo com que ele considerasse as imagens das prisões como objetos de reflexão. Assim como passou a estar mais atento para os diversos "olhos eletrônicos" da vigilância.

A pesquisa o levou à produção do documentário Tereza, filme que já ganhou diversos prêmios e pode ser considerado um marco de passagem na carreira de Goifman. E não poderíamos deixar de mencionar o bem elaborado CD-ROM que acompanha o livro e propõe ao navegador que o acessa um compêndio imagético e sonoro ou, mais precisamente, um hipertexto que coloca outras intervenções artísticas no mesmo patamar dos registros de pesquisa.

O trabalho de Goifman é ilustrativo, pois nos permite perceber o recurso da filmagem como propiciador de reflexões e não só de registros. Por causa do uso deste recurso o autor deteve-se em ponderações sobre as negociações que a gravação em si mesma gera. Negociações com os pesquisados e com as instituições onde estão presos. A produção do vídeo se torna um dos nortes da pesquisa, determinando a organização e exposição dos dados e, inclusive, dando origem a outras produções que, ainda que surgidas em complementaridade à pesquisa, ganham outras dimensões, passam a circular fora dos domínios acadêmicos e dialogar com públicos não especializados.

Vemos assim como a antropologia, não raro, se torna um caminho para o que poderíamos chamar de um olhar sensível para o outro e as realidades que o circundam. Nas palavras de Ruy Duarte, uma antropologia criada e entendida como uma ciência de relações humanas, sem nenhum desprezo à cientificidade. Ou seja, é muito comum encontrarmos exemplos de pesquisadores que se envolvem não apenas profissionalmente, mas também emocionalmente com suas pesquisas e os seus pesquisados. E os trabalhos podem ganhar contornos subjetivos inesperados. Não se trata de esperar que todos se tornem cineastas porque produziram registros em forma de imagens, ou que se tornem devotos por acompanhar um grupo religioso, ou ainda militantes políticos por conta de envolvimentos com grupos marginalizados. Contudo, temos que observar que a antropologia, enquanto disciplina voltada para o contato com o outro, torna-se um terreno fértil para que os sujeitos nela atuantes projetem suas subjetividades nos trabalhos desenvolvidos. E nisto reside uma poética que se estende em diferentes direções. 
Podemos pensar, por exemplo, no quanto algumas teorias ou alguns textos se tornam paradigmáticos na medida em que lançam mão de uma visão totalizadora da experiência humana. E quanto a isso nada mais exemplar do que o "Ensaio sobre a dádiva" de Marcel Mauss, cuja leitura nos remete diretamente a uma ideia de totalidade da experiência humana, como se todos os gestos práticos e conteúdos psicológicos dos sujeitos pudessem ser admirados em conjunto, pois Mauss atribui às ações de dar, receber e retribuir simbolizações que refletem convicções e esperanças com as quais o leitor pode se identificar mesmo diante das críticas já destinadas ao texto e ao modo como Mauss se apropria das etnografias que movimenta em seu pensamento.

Numa outra direção poderíamos pensar em textos como A África fantasma (1934) de Michel Leiris ou Tristes trópicos (1955) de Claude Lévi-Strauss. Pretendemos nos referir a estas obras mais detidamente, mas vale já a menção delas como textos híbridos, poligrafias inseminadas por arte e ciência. Embora sejam obras situadas em momentos distintos da antropologia francesa e tenham sido produzidas em contextos e sob temperamentos muito diversos, ambas constroem uma representação ou desenvolvem uma escrita em que se delineia uma continuidade entre prosa e vida.

Julgamos interessante ter essas duas obras em perspectiva ao lermos Ruy Duarte de Carvalho, já que ambas associam etnografia e diário de viagem, texto objetivo e subjetividades, tendo se tornado obras paradigmáticas e controversas na história da disciplina. Também não poderemos deixar de citar Os sertões de Euclydes da Cunha, obra singular no pensamento intelectual brasileiro. Cientificamente informada e literariamente efabulada, esta obra é um marco e bastante significativa para Carvalho. O autor declara em Desmedida: Luanda, São Paulo, São Francisco e volta (2006) que comprou uma edição do livro em 1968, o que nos permitiria supor, salvo engano, que Carvalho teria frequentado as páginas de Os sertões desde aquela data.

Ao sinalizarmos para uma possível convergência entre Euclydes da Cunha e Carvalho, de modo algum queremos dizer que há uma relação direta do tipo que possa ser pautada pela ideia de influência. Apenas chamamos a atenção para o fato de que a indistinção dos gêneros ou de outro modo, o entrelaçamento de gêneros que pertencem a diferentes situações discursivas, ou a diferentes tradições disciplinares não constitui assunto novo ou prática nova. 
Tendo em vista os exemplos citados, podemos supor a existência de uma poética do olhar antropológico, que se dá tanto no nível da construção das teorias, quanto no nível da composição de textualidades, ou seja, a linguagem empregada, os gêneros utilizados, as intenções do autor e os diálogos gerados com a recepção dos textos. Utilizamos a palavra poética em seu sentido mais convencional, ou seja, significando conjunto de recursos expressivos que pode ser de um gênero, de um autor ou de uma época.

As intervenções críticas que abordam a obra narrativa de Ruy Duarte e que serão mais bem detalhadas ao longo deste trabalho, em linhas gerais, assumem como um dos tópicos fundamentais a ser analisado, o entrecruzar de vozes. Em Carvalho, a subjetividade do escritor mistura-se a objetividade do pesquisador, originando uma narrativa considerada de difícil classificação, na medida em que nela se projetam discursos científicos, éticos e literários. Como o próprio autor enuncia em epígrafe do livro que ora abordamos e que citamos como epígrafe deste capítulo, texto e autor se confundem sendo impossível que o texto não registre a soma dos conhecimentos e a soma das experiências de seu autor.

Se considerarmos que esse é um dos grandes temas que cercam Carvalho e as abordagens sobre ele, nos sentimos convidados a ler O camarada e a câmera - cinema e antropologia para além do filme etnográfico e a entender o que o autor propõe sobre cinema e antropologia, e nos sentimos também convidados a assistir Nelisita e a seguir os relatos da experiência com o filme, pois, com essas referências, passamos a compreender melhor esse escritor que se quer o peso de suas preocupações éticas, científicas e estéticas em cada produção.

Não se pode ignorar também que, para além da questão central, ou seja, conciliar o rigor científico à exposição cinematográfica há sempre uma série de dificuldades ligadas à produção e distribuição dos filmes. O cinema, arte narrativa e coletiva, é financeiramente dispendioso, exigente e, muitas das suas dificuldades ultrapassam os desejos e as possibilidades de quem está a frente de uma produção.

No segundo tópico o autor entra na especificidade de um cinema africano e conduz sua abordagem para as relações entre cinema e política, defendendo posições claras para a atuação de cineastas africanos. A primeira defesa que o autor faz é da necessidade de "uma certa cultura antropológica" para o cineasta que atua em África. 
(CARVALHO, 1984, p.34) O autor esclarece que não se trata de querer que todo cineasta seja também antropólogo, porém, na medida em que os cineastas devem dialogar com o plural das realidades nacionais, abrir vias de comunicação com o universo das ciências sociais poderia lhes ser útil.

Ruy Duarte chama a atenção para o fato de que se o antropólogo encontra casos a serem investigados, os antropólogos ou etnólogos-cineastas que desempenham funções em seus países, se deparam com “casos em situação nacional”. Isso significa dizer que há uma ética, uma conduta a ser seguida quando se está em causa o seu local de origem. O cineasta que trabalha em território nacional trata de problemas concernentes aos seus concidadãos e é, em geral, com recursos públicos que pode executar o seu trabalho, já que em muitos lugares como em Angola (realidade imediata considerada pelo autor) o Estado é o único provedor de recursos para a produção cinematográfica.

Conforme nos lembra Teresa Nicolau, não podemos nos afastar do fato de que Carvalho "inicia o seu percurso cinematográfico no contexto fortemente politizado da luta pela independência em Angola" (NICOLAU, 2006, p. 45). Há um projeto ideológico que se orienta pela busca das identidades existentes na nova nação que insurgia naquele momento.

Ruy Duarte retoma a Carta de Argel do Cinema Africano ${ }^{2}$ que estabelece paradigmas para a produção do continente. Dentre esses paradigmas está a visão do cinema como meio para o autoconhecimento e autovalorização das comunidades nacionais. Partindo dos princípios estabelecidos por essa Carta, para o escritor torna-se inevitável um encontro entre o cineasta africano e as ciências sociais. Tendo em vista a necessidade histórica de renomear o que foi arbitrariamente nomeado, o cineasta africano não poderia ignorar as contribuições oferecidas pela antropologia.

Será preciso superar o ressentimento em relação à antropologia. O escritor não concorda com o posicionamento de cineastas que rejeitam o filme etnográfico e na sua argumentação pontua algumas oposições feitas a Jean Rouch por esses cineastas. Segundo Ruy Duarte, vários cineastas africanos se opõem ao cinema de Rouch, seja por se oporem à antropologia, seja por se oporem ao diálogo com estrangeiros, seja por

\footnotetext{
${ }^{2}$ Segundo Carvalho (1984), o documento foi adotado pela FEPACI (Fédération Panafricaine des Cinéastes) no seu II Congresso em janeiro de 1975.
} 
conta de mal entendidos com o próprio Rouch. Vale lembrar a importância do cineasta francês não só para a antropologia como também para movimentos estéticos importantes como a Nouvelle vague e o Cinema novo no Brasil.

Jean Rouch (1917-2004) é considerado um dos fundadores do cinema-verdade, tipo de filme que busca captar a realidade do momento filmado e, portanto, logo associado ao documentário. Rouch realizou filmes marcantes que documentam diferentes dimensões da vida no continente africano. Renato Sztutman, no texto "Jean Rouch um antropólogo-cineasta", propõe pensar a antropologia que o pesquisador constrói com o cinema. Teoria e prática se confundiam no artista, seu cinema era também o seu modo de fazer antropologia. E uma antropologia compreendida como algo que se faz compartilhando experiências. Um dos marcos do cinema de Rouch, Moi, un noir (1958) nos coloca diante de um jovem produzindo reflexões sobre sua vida em Abdijan, cidade para a qual imigrara a procura de trabalho. De modo que o espectador tem acesso não meramente às observações do cineasta, mas às trocas efetuadas entre os sujeitos, incluindo o observador, durante a realização do filme.

Jean Rouch, sem dúvida uma referência importante para Ruy Duarte de Carvalho, como também menciona Teresa Nicolau (2006), se tornou conhecido por promover em seus trabalhos alianças entre arte e ciência. O artista e o cientista estiveram sempre juntos na busca de uma nova antropologia. Sendo necessário enfatizar que esta antropologia não se norteava pela descrição de uma dada realidade social, mas pela criação do diálogo, pelo direito de fala do observado que o cinema e suas vantagens tecnológicas potencializam. (SZTUTMAN, 2004, p.52) Como veremos, essa antropologia compartilhada que define o trabalho de Rouch encontra ecos no cenário contemporâneo.

\section{"Para além do filme etnográfico"}

$\mathrm{Na}$ segunda parte, "Para além do filme etnográfico", depois de uma pequena introdução em que o autor chama a atenção para o fato de que seria um erro negligenciar o auxílio que toda forma de cinema pode oferecer ao antropólogo, mesmo um cinema não voltado para o documental, o autor nos remete a uma citação de M. M. Giraud retirada do no. 575 dos Colóquios Internacionais da CNRS, L'anthropologie en 
France (CONDOMINAS; DREYFUS-CAMELON, 1979), em que nos situa diante da crise da antropologia após a década de sessenta e as lutas por independências nacionais. Segundo a citação, tratou-se de um momento de ruptura em que a objetividade e a cientificidade da antropologia passaram a ser fortemente questionadas. Entra no centro da cena a acusação de ela ser uma disciplina a serviço da ação colonial.

Ruy Duarte ao nos introduzir na questão central desta crise, não deixa de afirmar que se a antropologia resiste é porque, afinal, a disciplina é mais que o conhecimento de sociedades ditas "tradicionais" e ela sabe encontrar novos objetivos e novos caminhos.

Vale notar que essa crise tem estado no centro de diferentes tradições antropológicas e que a antropologia norte-americana se tornou uma forte referência para os debates. A partir dela, muitas questões são consideradas atualmente, inclusive no cenário brasileiro. Um dos marcos geralmente apontado está no trabalho Writing culture: the poetics and politics of ethnography (1986), organizado por James Clifford e George Marcus. Afirma Vagner Gonçalves Silva (2005) que esta obra apresenta dois conjuntos de preocupações, um voltado para os problemas do trabalho de campo, outro voltado para a questão da "representação etnográfica" (SILVA, 2005, p.137). Podemos dizer que há ao menos duas questões essenciais: como efetivar o contato com o outro? Como representar o contato?

James Clifford em A experiência etnográfica: antropologia e literatura no século $X X$ (2002), instigante reunião de ensaios, sobretudo por nos inserir em alguns marcos significativos da tradição antropológica francesa, propõe questionamentos extremamente pertinentes. As preocupações de Clifford vão no sentido de compreender as relações entre o trabalho de campo e a escrita etnográfica. Como os antropólogos conseguem transformar uma experiência permeada por imprevistos e em tudo incerta, num relato objetivo e livre de quaisquer dúvidas? (CLIFFORD, 2002, p.21)

Vemos na interrogação de James Clifford certo inconformismo com uma etnografia que queira nos fazer crer que em suas páginas está fixado o real, o puramente observado. $\mathrm{O}$ autor desconfia dessa capacidade que outrora a antropologia se arrogou de traduzir uma cultura em fórmulas objetivas, inclusive apagando das etnografias as marcas reais do trabalho de campo.

Esta chamada antropologia pós-moderna ou "crítica" ou ainda "reflexiva", termos menos comprometedores, em boa medida é tributária da antropologia interpretativa proposta por Clifford Geertz nos anos 70. Geertz ao propor que as culturas 
devem ser vistas como textos e que esses textos não podem ser interpretados de forma totalizante, abriu margens para que os antropólogos passassem a olhar para o próprio texto etnográfico como objeto de análise. (SILVA, 2005, p. 141)

Em Obras e vidas: o antropólogo como autor (2005), Geertz nos apresenta reflexões sobre etnografias, nos levando a compreensão do quanto o gênero está marcado por soluções estilísticas mais comumente associadas ao terreno da literatura. É através de uma sólida construção narrativa que os antropólogos tornam coesa uma experiência que, na verdade, é atravessada por uma série enorme de imponderáveis. Entre o trabalho de campo e o texto etnográfico há uma distância que não pode ser desprezada.

Afirma Geertz que a crença que depositamos nos textos dos antropólogos tem muito mais a ver com a capacidade que possuem de nos convencer de que os dados e interpretações que apresentam resultam do contato direto que efetivaram. Nas palavras de Geertz o "estar lá” é decisivo (GEERTZ, 2005, p.15), pois é este ter "estado lá” que garante autoridade para o antropólogo "escrever aqui”, ou seja, fora das circunstâncias reais do contato e do trabalho de campo e no interior do registro de uma disciplina científica.

Tais questionamentos no campo da antropologia fizeram e fazem emergir novas propostas de etnografias que, muitas vezes, se voltam para si mesmas questionando o olhar do observador bem como as metodologias empregadas.

A antropologia durante muito tempo identificou-se com a metodologia estabelecida pelo inglês Bronislaw Malinowski, a chamada observação participante, definida pelo contato direto e prolongado ou intenso com as sociedades a serem investigadas, descritas e explicadas. Tal perspectiva aposentou a "antropologia de gabinete", permitindo ao antropólogo uma espécie de olhar lançado de dentro da cultura do outro. Após os anos 60, e a partir do contexto da descolonização (processo de construção e consolidação das independências), uma série de mudanças políticas e econômicas nas relações entre os países fez ressurgir a questão do trabalho de campo, questionando-lhe os limites e os objetivos. Já não seria possível a elaboração de etnografias como narrativas fechadas, nas quais o outro é apenas objeto do fazer científico e não um sujeito com o qual interações podem ser efetivadas.

O trabalho de Ruy Duarte em Vou lá visitar pastores (1999), para darmos um exemplo, articula-se aos pontos apresentados e às novas exigências para o trabalho do antropólogo. A transdisciplinaridade atravessa todo seu texto, o autor se vale de textos e 
de conceitos do campo da história, da sociologia, da botânica, da geografia e, é claro, da antropologia. Todos os esforços são utilizados para o exercício da compreensão. No entanto, tal empreendimento nunca se torna totalizador, o discurso é permeado por um metadiscurso que denuncia os limites da compreensão. E, ainda assim, não torna o autor isento de assumir suas posições políticas, de denunciar o que considera equívocos e abusos.

Do mesmo modo, podemos tomar a obra Nelisita, que apresentaremos no próximo item, como exemplo de novas posturas no fazer antropológico via narrativa cinematográfica. Uma das questões centrais mobilizadas pelo filme e pelos documentários anteriores a ele diz respeito à voz dos sujeitos. Como restituir a voz àqueles que ocupavam a posição de objetos de estudo? Deixar o outro falar por ele próprio se tornou uma das marcas éticas do trabalho de campo e das narrativas antropológicas. E poderíamos acrescentar que esta proposição ética configura uma das direções assumidas pela poética do olhar antropológico. Questões políticas, éticas e estéticas se imiscuem no fazer da ciência e tomam corpo nos resultados que nos são apresentados na forma de textos ou na forma de filmes, ou ainda outros suportes que entram para o roldão das investigações metodológicas.

O antropólogo Roque de Barros Laraia, ao refletir sobre ética e antropologia, nos traz a memória de uma carta que Franz Boas enviou em 1919 ao jornal The Nation acusando o governo dos Estados Unidos de utilizar quatro antropólogos como espiões. A denúncia de Boas custou ao mesmo sua perseguição nos meios acadêmicos americanos, portanto entre os seus pares, e não apenas por ser um estrangeiro como também pelo próprio crescimento da antropologia cultural, corrente da qual era uma referência, dentro da antropologia americana.

Segundo Laraia, a "reação indignada de Franz Boas da utilização da figura do antropólogo para acobertar atividades sórdidas constitui um dos primeiros momentos em que a questão da ética se relaciona com o procedimento antropológico". (LARAIA, 1993, p. 2)

Ainda segundo o autor, quando iniciou suas pesquisas em 1960, o código de ética, que em sua perspectiva resultava, sobretudo, da própria experiência dos pesquisadores no contato uns com os outros, poderia ser resumido em três pontos: não se envolver sexualmente com os informantes; ser mediador entre os interesses dos grupos pesquisados e a sociedade nacional, respeitando-os e defendendo-os; 
comprometer-se com a verdade científica. Em suas ponderações o quadro atual mudou consideravelmente. A ciência antropológica possui novos objetos, o antropólogo ocupa novas posições no campo profissional e aqueles princípios éticos que, praticamente, formavam um código costumeiro não são suficientes para que o pesquisador se oriente diante das questões contemporâneas. Além disso, como já expusemos delineia-se um novo contexto histórico no qual as questões que envolvem o contato com sociedades que sofreram colonização recente ou grupos sociais tidos por minoritários, bem como as produções culturais (particularmente textos) que resultam desse contato, estão sob o foco das reflexões contemporâneas, tanto no terreno da antropologia como em outras disciplinas.

Vejamos o que diz Vagner Gonçalves Silva:

(...) Atualmente, em contraste com os tempos heroicos da antropologia, quando eram produzidos textos sobre povos ágrafos para serem lidos pela sociedade letrada do investigador, muitos grupos investigados pertencem à mesma sociedade do pesquisador ou tem acesso aos seus escritos. Nessas situações, os textos etnográficos podem "voltar ao campo" interferindo nos discursos e práticas locais. Muitas dessas intervenções já são visíveis no campo etnográfico, pois os grupos sabem que ter sua história, mitos e tradições registrados nas etnografias afeta as estratégias políticas internas ou o relacionamento do grupo com a sociedade envolvente. (SILVA, 2005, p. 143)

Silva, que é pesquisador no campo das religiões afro-brasileiras, nos alerta inclusive para as negociações já existentes entre grupos pesquisados e os pesquisadores. Na medida em que certos grupos sociais são abordados com insistência, como é o caso de religiosos de tradições africanas no Brasil, as relações podem adquirir novos contornos, pois um dado a ser considerado é que o contato com o pesquisador pode servir como estratégia de legitimação não só frente à sociedade como também diante de outros grupos, o que pode gerar modificações no relacionamento entre os grupos e nas políticas internas de cada grupo. Certamente, tais questões geram discussões que não estavam tão presentes no horizonte do pesquisador quando este estava inserido nos "tempos heroicos" da disciplina, para retomar a ironia de Silva.

Embora o texto de Roque de Barros Laraia e o de Vagner Gonçalves Silva digam respeito às suas experiências brasileiras, os pontos em que tocam servem de referência para refletirmos sobre os rumos da antropologia em outros contextos. Como 
veremos a seguir, os procedimentos instaurados por Ruy Duarte de Carvalho no contato com os grupos da região sul de seu país orientaram-se por compromissos éticos que partem do pressuposto básico de que esses outros não conhecidos ou ignorados pela sociedade nacional são sujeitos com direito a participar do grande diálogo a constituir a própria comunidade nacional. O que significa dizer que não são objetos de pesquisa a ser conhecidos e explicados pelo cientista, nem fornecedores de acervos museológicos ou danças e cantos que possam ser absorvidos pela população urbana como imagens exóticas e pitorescas de uma chamada cultura nacional em processo de formação. São, na verdade, sujeitos com direito à voz e por isso mesmo, os procedimentos relativos ao trabalho de campo privilegiam a fala, o testemunho, o diálogo, a interação entre os pesquisados e o pesquisador ou entre os sujeitos filmados e a equipe de filmagem.

Em seu texto "O saber, a ética e a ação social", Roberto Cardoso de Oliveira reflete sobre a ética nas pesquisas em ciências sociais a partir de um questionamento que Sergio Paulo Rouanet lhe fizera envolvendo a problemática do relativismo na tradição da disciplina. Segundo depreendemos de Oliveira, o relativismo pode ter cumprido um papel importante ao combater o evolucionismo, no entanto, a ideia generosa de que todas as culturas possuem lógicas internas a ser, no mínimo, compreendidas, pode dificultar ou até mesmo impossibilitar o diálogo entre os sujeitos pertencentes às diferentes culturas. De acordo com Oliveira:

(...) a Antropologia tem se mostrado mais sensível ao reconhecimento das dificuldades de incorporar consistentemente o 'ponto de vista do nativo' que, desde Malinowski, a observação-participante, inerente à pesquisa de campo, tem procurado alcançar. (OLIVEIRA, 1990, p. 12-13)

A perspectiva teórica instaurada pelo método da observação-participante gerou uma tradição de textos etnográficos cuja presença do antropólogo pesquisador é autoritária. Daí a necessidade de se buscar "relações dialógicas simétricas" (OLIVEIRA, 1990, p. 13)

(...) Embora concretamente tal ordem de ralações não se dê com facilidade, visto a constatada desproporção entre os mundos em interação, contaminando de incômoda autoridade a figura do pesquisador, a busca da democratização dessas relações torna-se um imperativo da investigação. Apesar de todas as dificuldades de se efetivar uma antropologia plurivocal ou polifônica, onde a voz do Outro se faça ouvir juntamente com a do antropólogo, graças a uma determinada modalidade de 
"fusão de horizontes" (própria à disciplina e naquilo que deve distingui-la de uma filosofia hermenêutica), a questão ética se põe na medida em que as pré-condições para uma tal antropologia são permanentemente buscadas. (OLIVEIRA, 1990, p. 13-14)

Quando observamos a descrição de Carvalho acerca das ações que constituíram o seu contato com a etnia Nyaneka, como a importância dada à fala e a volta da equipe para exibir as filmagens ou a proposta de realização do filme de ficção, ainda que possamos discordar quanto a alguma medida específica, não podemos deixar de compreender a busca por essa antropologia plurivocal ou polifônica da observação de Roberto de Oliveira. Conforme nos indica, a ética se constrói na medida em que essa antropologia é almejada. Ou seja, é nas respostas dadas às dificuldades ou questões encontradas no trabalho de campo que o sujeito pesquisador pode construir relações dialógicas simétricas. Para isso torna-se fundamental a ideia de "fusão de horizontes" colocada por Oliveira. Podemos considerar que a proposta de construção de Nelisita, tendo em vista o conteúdo das estórias bem como a estética adotada, pautou-se por uma fusão de horizontes. Como veremos na análise detalhada acerca da produção do filme, Carvalho realizou a obra fílmica dialogando, respeitando dinâmicas culturais, mas também interferindo e propondo elementos de reflexão, particularmente em relação às condições desfavoráveis vividas pelos grupos no contexto em que estavam. Ou seja, não adotou a perspectiva do observador que só quer que o outro fale, pressupondo que a neutralidade seja possível. Conforme pondera Roberto de Oliveira, é preciso um ambiente em que ambos falem, pesquisador e pesquisado.

Sérgio Paulo Rouanet, em "Antropologia e ética", ensaio publicado em Malestar na modernidade (2001), nos chama a atenção para o fato de que o pesquisador é sempre o condutor dos trabalhos, neste sentido ele se tornaria um "produtor de diálogos”. Nas palavras de Rouanet:

(...) $\mathrm{O}$ antropólogo dialógico quer expor o etnógrafo, explodir o mito de sua imparcialidade, mostrar que sua prática profissional está embutida em relações de poder, e em vez disso produz "diálogos" em que a subjetividade do investigador só pode ser deduzida, na melhor das hipóteses, do tipo de perguntas que ele dirige ao informante. Quer valorizar o Outro, exibi-lo como interlocutor autônomo, e com ingenuidade comovente acha que a melhor maneira de fazê-lo é dar-lhe a palavra todo o tempo, esquecendo-se de que essa palavra é sempre uma palavra segunda, derivada, induzida pelo cientista. Substitui, com isso, 
um monólogo autoritário, em que só a voz autoral era ouvida, por outro monólogo, em que só o Outro fala. O antropólogo está tão ansioso em mostrar que não é colonialista que se esquece de que a melhor maneira de tratar os homens como iguais é argumentar com eles, e que o modo mais devastador de desprezá-los é não se dar ao trabalho de discordar deles. Não creio que o enfoque "polifônico" seja uma saída plausível para evitar esses impasses. A polifonia é uma rede de diálogos múltiplos, com muitas vozes, o que certamente nos protege contra a voz única, mas não nos aproxima da verdade. Na polifonia, muitos atores falam - mas não um com o outro. (ROUANET, 2001, p. 258)

A pertinente crítica de Rouanet chama nossa atenção para algo básico quanto ao diálogo, ou seja, é necessário ausência de assimetria para que os interlocutores argumentem sobre seus pontos de vista e possam assim produzir consensos. No entanto, quando o pesquisador parte da concepção de que só o outro irá falar, ele incorre em dois problemas que talvez este pesquisador supusesse resolvidos: ele continua na condução, não desfazendo a assimetria, e, com a sua mudez ou no seu desejo de coordenar o concerto de vozes com o qual entra em contato, deixa de produzir o verdadeiro diálogo, no qual os sujeitos envolvidos argumentam igualmente.

Rouanet parte dos trabalhos de Habermas e Apel para estabelecer os princípios da ética discursiva. Nisso vai encontro do quadro teórico utilizado por Roberto Cardoso de Oliveira com quem dialoga. Oliveira estabelece em seu texto já citado por nós, "O saber, a ética e a ação social", como um dos pontos de partida, um ensaio do filósofo alemão Karl-Oto Apel, intitulado "O a priori da comunidade de comunicação e os fundamentos da ética". Com a leitura de Oliveira compreendemos a seguinte ideia central: a produção do conhecimento está diretamente associada a "um acordo intersubjetivo no interior de uma comunidade de cientistas" (OLIVEIRA, 1990, p. 10) O que significa dizer que ninguém pode abster-se desta comunicação, mesmo solitariamente os cientistas estão em permanente diálogo com os seus pares, já que a produção do conhecimento depende de que outros sujeitos sejam capazes de verificar e compreender a lógica pertencente ao conhecimento produzido. Esse acordo intersubjetivo conduz a construção de normas necessárias à produção do saber.

Voltando ao texto de Rouanet, o ensaísta irá considerar que o verdadeiro diálogo ou discurso, palavra utilizada por ele, só é possível quando há simetria, portanto, no caso da antropologia esse diálogo ficaria restrito aos antropólogos e seus pares, 
conforme pondera, “(...) a validade do saber antropológico é determinada por um discurso teórico entre pares, tendo como objeto um conhecimento obtido a partir de um quase-discurso, realizado entre o antropólogo e a comunidade estudada." (ROUANET, 2001, p. 263) A diferença de estatuto entre pesquisador e pesquisados não pode ser negada ou driblada, configurando uma relação assimétrica que Rouanet designa pela expressão quase-discurso, ou seja, o diálogo permanece incompleto. A seguir, o autor se questionará se esse quase-discurso possui validade ou se seria lícito recorrer a tal estratégia. Rouanet responde que sim, pois é uma forma do antropólogo não negar a sua subjetividade. $\mathrm{O}$ autor parte da ideia de que é fundamental que o antropólogo participe ativamente da argumentação, pois desse modo suspende-se o relativismo que passou a pertencer à tradição da disciplina. Para o autor, quando o antropólogo age como se todas as culturas fossem equivalentes e todas as suas características igualmente válidas, ele abre mão da argumentação e do diálogo, criando um monólogo em que apenas o outro fala e, de qualquer modo, sob a direção do antropólogo. Devemos considerar que o exercício ético na disciplina pauta-se pela busca de métodos de trabalho de campo e práticas discursivas que compreendam o pesquisado como sujeito digno de voz, mas o antropólogo também não deve abrir mão de sua voz.

Para Ruy Duarte de Carvalho, se torna ainda mais evidente a questão de saber qual é o trabalho do antropólogo nos países novos. Havendo ou não uma tradição de antropologia colonial nos países de origem desses profissionais, será preciso que esses pesquisadores criem seus rumos e elaborem suas condutas. Ruy Duarte considera que o antropólogo não pode ignorar a sociedade na qual e para a qual serve. No entanto, há alguns riscos que devem ser considerados e evitados. Um deles é o risco de cair num militantismo mecânico na definição e constituição dos objetos de pesquisa. Outro risco é a tentação de passar a falar pelo outro, numa tentativa de decidir o que é melhor para a sociedade. Sua visão é a de que a "antropologia é uma relação social e a sua intenção de cientificidade não elimina a riqueza das relações humanas que estabelece". (CARVALHO, 1984, p.58) Podemos considerar que a antropologia foi para ele um exercício científico e político.

Certamente, podemos ver em Michel Leiris uma referência importante para Carvalho, tanto quando consideramos a escrita de Leiris, ou seja, seu estilo marcado por um ensaísmo literário que explicita as concepções ideológicas, as aspirações políticas e os valores subjetivos do autor que se projeta no texto, como quando consideramos os 
seus conteúdos e as suas proposições. Se tomarmos, por exemplo, o texto "O etnógrafo perante o colonialismo", publicado no Cinq études d'ethnologie (1950), leremos uma espécie de carta orientadora ao mesmo tempo política e científica. Um dos primeiros pontos abordados por Leiris é justamente a condição da etnografia como estudo das sociedades nascido no contexto colonial. Como nos lembra, "a etnografia surge estreitamente ligada ao facto colonial, independentemente da vontade dos etnógrafos". (LEIRIS, 2011, p. 200) Sendo assim, o pesquisador não poderá ignorar que se ocupa de sociedades subjugadas. E o antropólogo não pode ignorar que ele não observa a natureza e os seus fatos e sim, seus semelhantes. Também não pode ignorar que são, em geral, funcionários ou representantes vinculados e financiados por um Estado. Assim sendo, o autor considera que é função do antropólogo considerar as sociedades no seu estado real, ou seja, sociedades subjugadas sofrendo algum nível de intervenção. Tal compreensão aguda leva o autor a considerar que, mais que mediadores entre culturas, o antropólogo deve se tornar, nessas circunstâncias, "preparados para assumir o papel de defensores dessas sociedades e de suas aspirações, mesmo que tais aspirações choquem com os interesses apresentados como nacionais e sejam motivo de escândalo". (LEIRIS, 2011, p. 202)

Sigamos um pouco mais as orientações de Leiris:

Quanto à salvaguarda das culturas, já disse que, em meu entender, seria vão considerá-las tal e qual, pois, mesmo admitindo que isto seria possível, tal intenção equivaleria a petrificá-las e significaria, de resto, a manutenção do status quo, do ponto de vista do colonialismo. Sem nos arrogarmos o papel de guias - pois compete aos colonizados em si mesmos descobrir a sua vocação e não a nós, etnógrafos, revelar-lha a partir de fora - e sem tentar tão-pouco armarmo-nos em conselheiros (o que implicaria uma arrogância ainda bem próxima do paternalismo) devemos, contudo, considerar que, ao estudar as suas culturas, fornecemos a estes colonizados materiais susceptíveis, em todo o caso, de os ajudar a definir a sua vocação e que mais não fazemos, por outro lado, do que cumprir estritamente a nossa função de homens de ciência ao deixá-los extrair benefícios destes trabalhos que lhes dizem respeito em primeira mão, pela simples razão de eles constituírem a respectiva matéria. Criar para estes povos arquivos em que se possam basear - mesmo para aqueles que, conhecendo a escrita, estão em condições de ter uma história composta de outros dados, para além das tradições orais, mas que não dispõem ainda de métodos que lhes permitam efectuar o estudo positivo de sua própria vida social - é um trabalho cujo 
interesse não pode ser menosprezado, do ponto de vista não só do conhecimento em geral, mas da consciência que estes povos possam adquirir de si mesmos. (LEIRIS, 2011, 209-2010)

Quando Leiris expõe que o posicionamento frente às culturas que se quer conhecer não deve se pautar pela ideia de resgate ou conservação, somos imediatamente remetidos ao modo como Ruy Duarte de Carvalho trata as narrativas orais, seja no filme Nelisita, seja em sua obra poética, como veremos a seguir. O autor formula estratégias discursivas com o propósito de rearticular a tradição oral fazendo-a dialogar com o presente. Outro ponto fundamental diz respeito a autodeterminação dos povos. Como pontua Leiris, o antropólogo pode criar arquivos, mas cabe às populações transformadas em matéria de observação a escolha do modo como utilizar esses arquivos. Carvalho, assim como Leiris, considera que uma das urgências éticas é auxiliar os povos colonizados na busca e no exercício de suas vozes.

A principal tarefa dos antropólogos, sobretudo os dos países novos, talvez seja encontrar as formas adequadas de restituir a voz do observado. E para isto, o autor atribui um importante papel ao cinema. Nas relações entre cinema e antropologia, antropólogos e cineastas podem estabelecer vias de colaboração, quando a matéria do filme assim permitir, para além do filme etnográfico. $\mathrm{E}$ isto poderá permitir ao antropólogo compreender o que é um público de cinema e, mais particularmente, um público de cinema em África. Ruy Duarte vê na câmera um meio para facilitar as relações entre observador e observado, possibilitando que este se faça ouvir.

Além da parceria que pode ser estabelecida entre cineastas e antropólogos na realização de filmes, Ruy Duarte argumenta que a análise de filmes não pode ser dispensada pelo antropólogo. Se a obra cinematográfica é uma estruturação de signos ou uma representação da cultura, nada mais natural que a antropologia se aproprie do repertório produzido pelo cinema.

A análise das imagens produzidas pode revelar estruturas de pensamento ou auxiliar no entendimento das relações entre os indivíduos ou entre os diferentes grupos sociais. Nesse ponto, Carvalho afirma proximidade com o trabalho de Marc Ferro para a História, quando este propõe análises de filmes sem querer entrar no campo da estética ou da história do cinema. O objetivo central é tratar as imagens fílmicas como objetos que testemunham sobre a vida em sociedade. 


\section{"O caso em situação"}

$\mathrm{Na}$ terceira parte, "O caso em situação", podemos acompanhar as descrições e análises de Ruy Duarte sobre a produção e filmagem de Nelisita. Esta parte é fundamental para compreendermos as suas ações ao realizar o que podemos chamar de trabalho de campo, já que as filmagens da ficção estão orientadas por uma metodologia e por um compromisso ético atinentes ao metiê do antropólogo. O modo como procura relacionar sua compreensão do trabalho do antropólogo aos limites dados pelo contexto que cerceiam e conduzem este trabalho torna-se bastante claro em seu texto. Em todas as decisões e encaminhamentos relatados acompanhamos o desenho de uma ética norteada pelas reflexões contemporâneas acerca dos caminhos da antropologia e, particularmente, da etnografia e do trabalho de campo.

É esclarecedor estarmos atentos para uma ponderação que o autor expõe logo no início desta parte, ou seja, a ideia de que é difícil para ele separar a produção do filme das questões propriamente teóricas. Mais precisamente, saber se os filmes são os resultados de uma compreensão teórica ou, em si mesmos, um esforço de compreensão. Neste aspecto, fica patente para nós, como já expusemos anteriormente, a formulação de um cinema como campo aberto em que as experimentações e as próprias condições de realização do filme realimentam as reflexões. Obviamente toda experiência advinda de um trabalho de campo pode contrastar com as teorias e hipóteses prévias reorientando a condução do trabalho para promover as necessárias adequações. No entanto, parece-nos correto assinalar que a produção de imagens gerou para a antropologia um novo conteúdo.

$\mathrm{O}$ argumento do filme foi estabelecido a partir de duas peças da tradição oral nyaneka, registradas no trabalho do Pe. Carlos Estermann (1971), a partir de narrações feitas por Antonio Constantino Tyikwa e Valentim (?). Antes da rodagem desta ficção, Carvalho já havia entrado em contato com estas populações, pois realizara de 1977 a 1981 várias horas de documentário, constituindo a série Presente Angolano, Tempo Mumuíla. Segundo o autor, o início de Nelisita coincidiu com a última etapa do projeto, que era a exibição de todos os documentários da série. Em novembro de 1980 é exposta às populações a ideia de fazer o filme de ficção. Segundo o autor, ele obteve não só a aceitação como também o empenho do grupo. 
O filme contou com a família alargarda do mais velho Tyongolola para a composição do elenco, apenas três atores não fazem parte desta família. Os Mumuílas estão localizados na Huíla e junto aos Mugambwe constituem a etnia Nyaneka. De acordo com Ruy Duarte de Carvalho, a presença colonial mais efetiva na região se dá no final do século XIX com a penetração de colonos portugueses e boers. Contudo, esta presença não alterou de forma drástica as principais componentes econômicas: a criação de gado e a agricultura de subsistência. Nas considerações de Carvalho, a organização política também pôde ser mantida durante a administração colonial, inclusive ganhando certa importância durante a fase de transição entre o aparato colonial e o novo governo do país independente (lembramos que a independência de Angola data de 1975). Afirma o pesquisador que esta estrutura de poder encontrava-se já em derrocada ao entrar em contato com os grupos. De todo modo, Ruy Duarte considera que encontrou no espaço "sinais de permanência de práticas e relações" anteriores à administração colonial e à experiência revolucionária, principalmente se compararmos esse espaço ao setor urbano ou às regiões mais dominadas pelos portugueses. (CARVALHO, 1984, p.71)

Os intérpretes do filme estavam em contato com Ruy Duarte desde 1977. Os membros da equipe eram recebidos pelas populações como se fossem enviados do governo. Mesmo o regime colonial já havia enviado fotógrafos e até cineastas interessados em imagens folclóricas. As diferenças, na argumentação de Ruy Duarte, foram logo verificadas pelos grupos, pois ficou estabelecido que não teriam compensações monetárias. A compensação seria a realização do filme com a possibilidade de os Mumuílas se revelarem. Também causou surpresa o novo destaque que era dado à palavra e ao testemunho. Outra surpresa foi a equipe ter retornado mais de uma vez com as filmagens já efetuadas para serem exibidas. Vale notar a diferença de posicionamentos assumidos: para o documentário a compensação estava no próprio filme e na possibilidade de os Mumuílas compartilharem seus problemas diante da nova nação angolana. Já na produção da ficção, os envolvidos foram remunerados de acordo com o que lhes fora exigido na produção e seguindo um padrão salarial no mesmo nível da equipe.

Os procedimentos elencados acima, como a volta da equipe para mostrar as filmagens para o grupo, a importância dada à fala, a proposta do filme de ficção com remuneração que se diferencia do testemunho, na medida em que constitui uma possibilidade de reflexão com maior distanciamento, todos esses elementos nos 
encaminham para as discussões já abordadas. São procedimentos ou ações que remetem aos princípios éticos e científicos que procuramos apresentar, ainda que sucintamente, recorrendo aos textos de Roberto Cardoso de Oliveira, Sérgio Paulo Rounet e Michel Leiris. Os dois primeiros, embora inseridos no contexto brasileiro, travam uma discussão que põe em relevo as questões mais atuais da antropologia. E recorremos a Leiris por constituir uma referência direta para Ruy Duarte de Carvalho. Podemos verificar que os princípios éticos a partir dos quais Carvalho formula sua atuação, já estavam presentes no horizonte de Michel Leiris. Obviamente, são questões que ultrapassam os autores a que recorremos. O objetivo principal é o de apresentar alguns pontos substantivos com os quais possamos compreender os caminhos traçados por Carvalho. Os grupos terem acesso aos seus testemunhos, assim como se representarem ficcionalmente parte do desejo de criar momentos propícios a autorreflexão. O que se torna extremamente relevante para a compreensão do lugar que ocupam ou desejarão ocupar no conjunto da sociedade. Na medida em que o antropólogo detém a consciência de que há processos sociais e históricos em curso como colonização ou formação de um Estado, ele não poderá executar seu trabalho científico ignorando as circunstâncias históricas e sociais que envolvem a todos.

Para nos aproximarmos mais do filme vamos reproduzir a sua sinopse.

\footnotetext{
A fome domina o mundo e apenas restam vivos dois homens com as suas famílias. Um deles parte em busca de comida e encontra um armazém onde certos "espíritos" guardam enormes quantidades de gêneros alimentícios e roupas. Apropria-se do que pode transportar e volta mais tarde acompanhado do seu vizinho. Este deixa-se apanhar e denuncia aos "espíritos" a sua morada e a do seu companheiro. Os "espíritos" aprisionam todos menos uma mulher grávida, para que ela venha a ter o filho e eles venham assim apossar-se de mais um ser vivo. Nasce Nelisita, aquele que se gerou a si mesmo. Ludibria o "espírito" que o vem buscar a ele e a sua mãe. Só esta acaba por ser levada. Nelisita parte em sua busca e apresenta-se ao rei dos "espíritos" para reclamá-la. O rei dos "espíritos" alicia Nelisita para passar para o lado dos que detém a comida. Nelisita resiste. É depois submetido a várias provas, mas socorre-se dos animais da criação, seus aliados, para vencê-las a todas. Perante o poder de Nelisita, os "espíritos" fogem amedrontados. Nelisita salva os seus e recondu-los a casa montados no carro dos "espíritos" e transportando tudo o que se encontrava no seu armazém. (CARVALHO, 1984, p.68)
}

Segundo Carvalho alguns elementos utilizados no décor tinham a finalidade de fazer com que as narrativas orais dialogassem com a contemporaneidade de Angola, pois naquele momento o acesso a vários bens de consumo era muito difícil. O filme, portanto, comporta uma crítica à situação de carência vivida no país a partir da retomada das narrativas orais, pois tematizavam situações de carência. O cineasta 
inclusive fez coincidir a entrega de bens de consumo aos grupos com a finalização do filme, algo que, segundo relata, faz parte da troca de serviços e interesses estabelecidos na região. Conforme lemos na sinopse, o filme termina com a festa de recebimento dos produtos armazenados pelos "espíritos". A cena que podemos ver é a cena real de entrega dos produtos estabelecendo uma quebra entre o ficcional e o documental.

Esse dado nos permite observar o uso do cinema como forma de intervenção direta numa dada realidade. Com as estratégias agenciadas, o cineasta lida com as questões práticas, pois é preciso algum nível de conformação às dinâmicas existentes na cultura na qual se propôs inserir e, por outro lado, consegue uma boa formalização estética, pois a estrutura construída lhe permite fazer com que os tempos se comuniquem: o tempo da estória ${ }^{3}$ e o tempo da história. A estória filmada nos conta sobre uma má distribuição de mercadorias, pois há aqueles que acumulam enquanto a fome se generaliza e, isso nos remete diretamente aos problemas de acesso aos bens vividos por aqueles grupos e por outros em Angola.

Algumas questões técnicas precisam ser mencionadas para esclarecer ainda mais quanto ao tipo de cinema proposto. Foi utilizado filme de $16 \mathrm{~mm}$ e optou-se pelo preto e branco, equipamento leve e equipe reduzida, apenas cinco (realizador, assistente de realização, operador de câmera, operador de som e assistente de câmera). Muitos problemas foram enfrentados na revelação dos filmes em laboratório, no som, na montagem. Obviamente tudo isto reflete as condições periféricas do país. Embora também não possamos ignorar o contexto político. Cita o autor que era agosto de $1981 \mathrm{e}$ os sul-africanos invadiam o sul do país.

A equipe reduzida teve por objetivo não perturbar, além do necessário, a vida da comunidade. No entanto, tal medida criou dificuldades, pois muitas funções no plano da produção não estavam asseguradas. $\mathrm{O}$ equipamento leve garante mobilidade à filmagem, o que desde Jean Rouch tornou-se uma das marcas do chamado cinemaverdade. $\mathrm{O}$ equipamento leve e o abandono do tripé permite à câmera acompanhar com mais liberdade as movimentações que se dão diante dela, seguir as personagens na

\footnotetext{
${ }^{3} \mathrm{O}$ uso do termo não é consensual, no entanto, pensamos que o uso de estória é útil quando estamos nos referindo a narrativas de tradição oral. Informamos que o termo com este sentido encontra-se registrado no Dicionário do folclore brasileiro de Câmara Cascudo e que Ruy Duarte faz uso dele sem maiores discussões.
} 
fluidez e na verdade do gestual de seu corpo. Assim, garante-se a movimentação da câmera ao sabor dos acontecimentos.

O uso do preto e branco também foi motivado por razões estéticas, seja porque o cineasta acreditava que essa modalidade se ajustava bem à estória, seja por entender que o uso da cor induziria à "folclorismos". (CARVALHO, 1984, p.74) Embora não possamos captar todo alcance do uso desta expressão no contexto em que ela é utilizada, como espectador consideramos que o uso do preto e branco contribui para a sobriedade da imagem ${ }^{4}$. O preto e branco ao não proporcionar identificação direta entre as cores existentes e as cores da tela, projeta a imagem para fora das imagens rotineiras que cercam o nosso olhar, conferindo a ela especificidades. Para o filme em questão, acreditamos que o uso do preto e branco ajusta-se a matéria épica contida na obra. $\mathrm{O}$ filme possui um herói épico que sem titubear sabe exatamente como cumprir sua função, pois está plenamente integrado aos seus. O uso do preto e branco contribui para o clima não prosaico que a matéria exige.

Ruy Duarte destaca a questão ética de se filmar um conto oral. Pois, na medida em que um texto oral pertence ao seu grupo de origem, como determinar a versão adequada? Além disso, como nos ensina Paul Zumthor, há que se levar em consideração a voz e o corpo em performance. Cada vez que uma peça oral vem à cena é única, pois o evento e a palavra viva ganham expressividades que não se repetem exatamente da mesma forma. No ponto de partida está a fixação de algo que não possui vocação para a fixidez. Uma saída encontrada foi fazer a estória contada dialogar ao mesmo tempo com duas narrativas nyaneka entrelaçadas e a realidade angolana. Ou seja, o filme não ignora que Angola e as sociedades que nela habitam e não se situam ainda no interior de uma identidade nacional, estão em plena mudança, em plena transformação. Ruy Duarte arma a contação ${ }^{5}$ da estória no interior do filme fragmentando a ficção em dois tempos: o tempo das ocorrências na estória, da ação, e o tempo da narração da estória, sendo que a estória é contada para os mesmos "atores" que a encenam, indicando, segundo Ruy Duarte uma passagem para a realidade. Nas considerações de Teresa Nicolau:

As características da oralidade conferem ao cinema de Ruy Duarte de Carvalho o centro da sua própria significação, ou

\footnotetext{
${ }^{4}$ Agradecemos a oportunidade de assistir ao filme junto à turma de pós-graduação coordenada pela Profa. Fabiana Carelli no primeiro semestre de 2012.

${ }^{5}$ Embora o termo não soe bem, devemos notar que, entre nós, ele vem sendo utilizado com o sentido preciso de contar (dar voz, trazer à cena) peças de tradições orais para um público de ouvintes presentes.
} 
seja, o protagonista central do filme não é Nelisita mas sim o contexto do próprio filme: o seu ambiente, o seu espaço, a sua cultura, a sua sociedade. (NICOLAU, 2006, p. 46)

A introdução de elementos como automóvel e vestuário, caminhão, motocicleta também possuem a função de operar uma quebra entre tempo mítico e tempo histórico, espaço cênico e espaço real, personagens e intérpretes, ficção e documentário.

Com relação a esse tratamento da oralidade vale nos referirmos a um livro de poemas do autor. Ondula savana branca foi primeiramente publicado em 1980 e depois integrado à antologia Lavra - poesia reunida de 1970 -2000, de 2005, publicação em que recebeu o novo e sugestivo título Da lavra alheia I. As preocupações de Ruy Duarte de Carvalho com a tradição oral em África estão desenhadas e bem articuladas no formato do livro.

O livro, que possui poemas produzidos a partir de diferentes materiais, apresenta-se dividido em três partes: Versões, Derivações e Reconversões. Segundo o autor, o trabalho foi orientado por quatro objetivos fundamentais: 1. adaptar para língua portuguesa peças já estabelecidas em língua inglesa ou francesa, o que corresponde ao item Versões; 2. reformular poeticamente peças já estabelecidas em língua portuguesa, aí temos as Derivações; 3. transformar em poesia material que possui uma inegável carga poética, também inserido no capítulo das Derivações; 4. transformar em poesia material que, embora não fosse tratado como tal e tivesse ficado no meio restrito de especialistas também podia ceder a formalizações poéticas, as Reconversões. Ainda que, as fontes sejam trabalhos antropológicos e o tratamento conferido pelo autor não dispense o rigor, não podemos deixar de lado sua ênfase ao declarar que procurou fazer poesia. Uma poesia que respeitasse as fontes a que teve acesso. No final do livro, o autor faz publicar notas específicas para cada poema, disponibilizando as fontes utilizadas.

Não faz parte dos nossos objetivos, ao menos para este trabalho, nos determos sobre a vasta e notável produção poética de Ruy Duarte de Carvalho. Apenas queremos chamar a atenção para dois dados: a marca de seu olhar antropológico, já colocada na poesia, e o tipo de relação que cria com a tradição oral, ou seja, não se trata de salvaguardá-la, para voltarmos a um termo utilizado por Michel Leiris, mas sim de revisitações que objetivam a reflexão sobre o presente. 
Estamos certos de que o primeiro dado está diretamente relacionado à natureza deste trabalho, no entanto, optamos por não abordá-lo por duas razões: primeiro, resolvemos abordar a narrativa e a poesia exige a imersão num outro quadro de referências; segundo, estamos considerando que a partir do trabalho do autor no cinema, o seu referencial antropológico se torna mais evidente, cremos que é possível sustentar esta posição tendo em vista a publicação de $O$ camarada e a câmera - cinema $e$ antropologia para além do filme etnográfico. Além disso, é pertinente registrar que as datas indicadas para a produção de Ondula savana branca (1977-1980) coincidem com a produção dos documentários.

Com relação ao segundo dado, pensamos que no quadro armado por Carvalho na introdução aos poemas fica completamente afastada qualquer ideia de pureza que, porventura, algum leitor possa ter. Não se trata de querer chegar ao texto original, repetido por muitas memórias até ser fixado pela letra. A ideia que temos a partir das proposições do poeta é a de textos em mobilidade, ainda que escritos. As versões, derivações e reconversões nos colocam diante de um trabalho voltado para a tradição oral de diferentes partes do continente africano tendo em vista as fontes escritas disponíveis. Também em Nelisita, o espectador se verá diante de uma tradição oral que se encaixaria no plano das derivações, se quiséssemos associá-las às definições propostas em Ondula savana branca. Veremos as estórias transformadas ou reformuladas poeticamente para que pudessem ir ao encontro da temática social que o diretor-antropólogo, Ruy Duarte de Carvalho, propôs abordar. Fica para nós, leitores, a sugestão de que o trabalho do escritor ou do antropólogo africano não deveria se orientar por uma recusa acrítica dos trabalhos produzidos no bojo da colonização. $\mathrm{O}$ autor nos induz a refletir sobre a necessidade de um olhar cuidadoso, pois nestas fontes podem residir estímulos, formas de resistência e caminhos a serem retomados. Faz-se necessário considerar as ambiguidades da colonização no processo de construção das identidades nos novos países. As textualidades construídas no ou pelo império podem constituir tradições nos novos países e estabelecer noções de continuidades, elas podem não ser inteiramente formas de expressão do opressor. Assim, consideramos que o autor nos indica a possibilidade de um movimento pendular entre passado e presente, sendo que o primeiro pode ser afirmado ou negado na formação do segundo.

Quando Carvalho utiliza como fonte as peças recolhidas por Esterman, ele estabelece uma relação com a oralidade e a escrita ao mesmo tempo. Temos assim 
textos orais que passaram para a escrita e voltaram para uma oralidade estetizada. Uma oralidade repensada nos domínios da arte cinematográfica. Assim como os poemas de Ondula savana branca nos levam a uma oralidade repensada nos domínios da arte poética versificada e escrita. Os elementos utilizados para recontar as estórias ou, mais precisamente, a formalização estética que as estórias recebem nos levam para significações de outras ordens. Para o espectador do filme fica ressaltado o desejo de crítica social e política, já que a introdução de elementos como um carro bôer do século XIX, caminhão, óculos escuros utilizados pelos "espíritos", dentre outros elementos, retiram a estória de seu caráter atemporal ou mítico para situá-la nas questões políticas e sociais mais prementes daquele momento. Assim, a estória mítica que conta sobre a má distribuição das riquezas deve ser pensada tendo em vista contextualizações políticas nacionais ou internacionais, conforme se der a apreciação dos símbolos por parte do espectador.

Numa outra direção, podemos considerar que a retomada das estórias orais a partir de Esterman representa, por parte de Carvalho, uma noção de continuidade literária. Continuidade em relação aos seus textos anteriores e vale lembrar também de Como se o mundo não tivesse leste (1977). E continuidade em relação ao seu contexto de produção, já que a narrativa angolana possui diversos autores que, ou fizeram recolhas de narrativas orais, ou procuram trabalhar o tema vasto da oralidade em suas composições escritas. Do primeiro grupo podemos citar nomes como os de Castro Soromenho e Oscar Ribas. Do segundo grupo José Luandino Vieira é o nome mais expressivo.

Retomando as notas em que Carvalho discute a realização do filme, segundo afirma, não houve grandes problemas de comunicação com os atores. Optou-se pela utilização da língua do grupo, o lumuíla. Esta opção seria mantida mesmo que todos pudessem se comunicar em português. No entanto, foi preciso o auxílio de um intérprete, pois embora houvesse uma compreensão geral do português, nem a equipe poderia se comunicar em lumuíla com perfeição, nem o grupo em português. $O$ argumento do filme foi exposto nas duas línguas até que todos o compreendessem bem. E, antes da rodagem de cada plano, os diálogos eram retomados em português e vertidos para o lumuíla. 
Ainda que tenha havido muitas dificuldades técnicas (e o autor nem chega a enumerar todas) o filme não cede a facilitações. Todos os planos são significativos, evitando-se assim planos que servissem apenas de ligação entre dois outros. Outro elemento a que o filme não recorre é o comentário em off. Nem os documentários nem Nelisita recorrem ao discurso por detrás das câmeras, efetuado por uma voz que, estruturalmente, se coloca acima das demais, pois, na medida em que explica ou descreve uma ação, passa a filtrá-la e a dominá-la.

Com nos orienta o autor, não se trata de registrar técnicas e práticas concernentes ao cotidiano das populações em questão, mas de abordar "a relação viva entre os objetos, os homens, as instituições e as ideias." (CARVALHO, 1984, p.81) Sendo assim, recorre-se à gramática cinematográfica e a uma articulação dos recursos disponíveis. Segundo o antropólogo é mais difícil, contudo uma atitude ética necessária. Por isto, o autor considera que não é necessário explicar que um boi é morto por asfixia, já que o que importa no filme é a morte do boi e não o modo como ele é morto naquela cultura. Apreciamos a execução de um cinema, que está além do filme etnográfico e, no entanto, está plenamente informado pela antropologia.

Devemos observar que o problema apontado para o discurso em off está muito mais associado a uma prática etnográfica voltada para observação e explicação da cultura do outro do que a modalidade técnica em si mesma. Quanto a isso, Jean Rouch produziu uma obra exemplar. Moi, un noir (1958), faz um uso bastante expressivo da voz em off. Só ouvimos a voz de Rouch no início do filme, depois passamos a seguir a voz da personagem que o cineasta elege para flagrar o que pode ser o cotidiano de um jovem que imigra para uma cidade grande, Abdijan, em busca de trabalho. De acordo com Sztutman (2004), podemos verificar o discurso em off fragmentado em três níveis: um primeiro nível, em que ouvimos a voz de Rouch ou a voz do protagonista; um segundo, em que ouvimos os diálogos entre os personagens e, num terceiro nível, os depoimentos dos protagonistas registrados depois e sobrepostos às imagens, o que nos permite acompanhar as reflexões dos atores. A estruturação do discurso em off nos coloca diante de vozes em que os observados comentam as imagens e a si próprios. Obviamente, com relação a Nelisita, concordamos com as observações de seu realizador. Se a ação fosse interrompida para explicar ou comentar a técnica pela qual um boi é morto, isso representaria uma violência para a sequência da narrativa. De fato, não é neste nível que o filme converge para as suas relações com a antropologia. 
A argumentação segue com ponderações sobre a relação com o cinema no contexto angolano. O autor afirma procurar fazer filmes adequados à realidade angolana. Nisso não desconsidera que há vários interesses em jogo e cabe ao cineasta promover o equilíbrio possível entre as forças. Seguindo um pouco a sua reflexão, colocada como ponto de partida a merecer debates e outros desenvolvimentos, há os interesses do Estado, pois até o momento de escrita do texto, era o único produtor de cinema no país; há os interesses do público; há os de quem se deixa filmar e finalmente, os interesses de quem filma e é o responsável por "fornecer um produto que respeite a todos". (CARVALHO, 1984, p.84)

Em relação aos interesses do Estado, Carvalho aponta para três níveis de intervenção: propaganda ideológica, política cultural e autoinformação. Aqui vemos o cinema encaixado numa ideia de civismo, como meio efetivo para formar e educar, para a recolha e divulgação do patrimônio nacional e também para o Estado se interar quanto às diversidades do território. Com relação aos interesses do público, o autor assume que isso extrapola as intenções do texto, mas não deixa de sublinhar e com uma postura subjetiva, a necessidade de diversão e evasão, além da instrução. Para os indivíduos ou coletivos que se permitem filmar, a compensação não pode restringir-se a um pagamento material, o mostrar-se, o dar a conhecer sua existência, colocam-se como compensações que devem fazer parte do projeto desse cinema.

Para as categorias estabelecidas por Carvalho, produtor, público e grupos filmados, os interesses ultrapassam o próprio filme, na medida em que repercutem a complexidade das relações sociais. Sem embargo, para quem filma, "o filme é o seu próprio lugar social e fazer filmes corresponde ao seu papel no âmbito das responsabilidades cívicas que o situam em sociedade”. (CARVALHO, 1984, p.87)

Nas conclusões o autor esclarece, mais uma vez, que o seu principal objetivo foi tratar das relações entre cinema e antropologia, tendo sempre em vista um contexto angolano. Angola, como a maioria dos estados africanos, possui uma grande diversidade de culturas e em estados diferentes de desenvolvimento convivendo no mesmo espaço nacional. Sendo assim, a antropologia tem funções a cumprir nos planos da compreensão dos problemas, das análises e, por conseguinte, da descoberta e aplicação das soluções. 
Nosso principal objetivo neste capítulo foi propor o debate das relações entre discurso artístico e discurso científico em Ruy Duarte de Carvalho tomando como ponto de partida o seu trabalho no cinema, particularmente na produção do filme Nelisita. Suas reflexões registradas em $O$ camarada e a câmera - cinema e antropologia para além do filme etnográfico nos permitem uma boa entrada em algumas das preocupações artísticas e científicas deste nosso poeta, cineasta, antropólogo e ficcionista. A proposta nos permite alargar um pouco a visão para pensar as relações entre narrativa e antropologia para além dos textos escritos, em geral, mais abordados.

No trabalho com o cinema concretizam-se temas e perspectivas do autor. Acompanhar as suas reflexões sobre cinema e antropologia nos permite acompanhar a mescla de gêneros, a eleição dos povos do sul como fonte e espaço de sua poética, a crítica social na seleção dos temas, a definição de posturas éticas, as reflexões políticas, as dúvidas e saídas encontradas para o tratamento estético das formas orais, a importância da antropologia francesa em sua formação. Em relação a este último tópico vale frisar que Jean Rouch é o único cineasta realmente debatido em seu texto. Embora o autor registre algumas das críticas efetuadas ao cinema de Rouch por cineastas africanos, Ruy Duarte as considera insuficientes para abalar o significado do cineasta francês, pois constituem uma recusa acrítica que não gera avanços no debate.

Os temas elencados anteriormente nos permitem acreditar que viajar com Ruy Duarte para ir ao encontro do tempo do cinema que realizou em Angola é uma forma de potencializar algumas das ideias já articuladas pelos críticos e pesquisadores que têm se dedicado ao autor. 


\section{Capítulo 2}

\section{Viagens em textos}

Um dos assombros que a literatura de Ruy Duarte pode causar a seus leitores diz respeito ao número de obras e autores que cita. Ler Ruy Duarte é ler também os textos que o formaram e informaram. O autor nos encaminha para as suas leituras. De modo que o exercício de interpretação exigirá do leitor alguma disponibilidade para ir ao encontro das referências trazidas pelo autor. Pretendemos uma análise crítica que tome como ponto de partida a intertextualidade definida pelas citações de obras e autores.

Sem dúvida, a poética construída nos trabalhos de Ruy Duarte inclui a experiência da leitura. O narrador mostra-se como leitor. Conta-nos sobre os livros que leu. Sobre aqueles que o estimulou, que o ajudou nos caminhos de sua própria textualidade. Sua obra nos sugere uma poética da leitura. O compartilhar leituras é uma das tônicas da estética verbal de Carvalho.

Michel Leiris, antropólogo francês que está entre as citações de Ruy Duarte, possui textos fascinantes e de difícil classificação. Como nos informa Antonio Motta (2006), Leiris cultivou "gêneros fronteiriços que vão desde diários íntimos, relatos de viagens, etnografias, tauromaquia, autobiografia e missivas até incursões pela poesia, romance e ensaísmo diverso (...)” (MOTTA, 2006, p.265) Certamente uma referência importante para Ruy Duarte e a sua transumância por discursos, para utilizarmos a feliz expressão de Sandro Ornellas. O antropólogo angolano, formado também em contexto francês, não poderia ignorar as referências importantes que atuaram sobre a constituição do saber antropológico naquele país. Sua tese de doutorado fora concluída na École de 
Hautes Études en Sciences Sociales, em 1986. Publicada em 1989 sob o título de Ana a manda - os filhos da rede - identidade colectiva, criatividade social e produção cultural da diferença: um caso muxiluanda, contou com o prefácio de Jean Copans do qual retiramos o trecho a seguir:

Conheço o Ruy há muito tempo: primeiro como cineasta (o ciclo mumuíla), depois como cineasta-estudante (Nelisita foi também memória para o diploma da EHESS), enfim como estudante-cineasta (a obra que se segue). Mas estou a ser inexacto ao utilizar o termo estudante, de conotação administrativa, porque ele se tornou para mim num amigo que quer mudar a África, a sua África. Juntos nos interrogamos sobre as vias do conhecimento e das transformações que a África esboça, muitas vezes sem querermos que fosse exactamente assim.

James Clifford (2002), na primeira parte do ensaio intitulado "Sobre o surrealismo etnográfico", chama a atenção para a proximidade do desenvolvimento da etnografia e do surrealismo na França das décadas de vinte e trinta. O antropólogo norte-americano assinala que irá se referir ao surrealismo de um modo expandido "para circunscrever uma estética que valoriza fragmentos, coleções curiosas, inesperadas justaposições" (CLIFFORD, 2002, p. 133) e à etnografia não como uma técnica de pesquisa empírica, mas como a atitude mais geral de observação de realidades culturais tidas por estranhas ou exóticas aos olhos do observador (CLIFFORD, 2002, p 136). Não se trata de verificar exaustivamente os campos como unidades claras e definíveis, segundo o próprio autor. Clifford discutirá o histórico de personagens que participaram deste contexto intelectual permeado por atitudes etnográficas e surrealistas.

Nesse sentido, o percurso e o trabalho de Michel Leiris são exemplares. Leiris esteve, num primeiro momento ligado ao grupo de André Breton, teórico do surrealismo. Depois rompeu com o grupo, mas, de todo modo, é possível perceber a 
permanência de ideias surrealistas em suas obras. Leiris, na companhia de Marcel Griaule e outros pesquisadores, participou da Missão Dakar - Djibouti, "que por vinte e um meses atravessou a África do Atlântico ao mar vermelho, ao longo da margem inferior do Saara." (CLIFFORD, 2002, p. 179) Iniciada em 1931, tinha o objetivo de promover pesquisas etnográficas e enriquecer coleções museológicas.

Em A idade viril, na tradução de Paulo Neves, lemos uma fascinante autobiografia, em que autor promove uma análise de sua formação mobilizando um inventário ou uma coleção de dados pautados pelo erotismo. A cronologia ou a sequência de fatos perdem espaço para um texto com memórias bem selecionadas que perseguem tópicos recorrentes. A narrativa de Leiris inicia por descrições de seu corpo e de seus gestos com certa objetividade, como se pudesse se ver estando fora de si e transformando esta visão na apreciação de algo exótico. Como se desenvolvesse uma etnografia tendo seu corpo por objeto inicial. No segundo capítulo passará a um relato sobre as óperas que assistiu na infância e que lhe causaram forte impressão para justificar que isso o levou a um discurso sempre marcado por alusões e metáforas. Na sequência de sua narrativa encontraremos a revelação de duas alegorias que estarão presentes na armação desta autobiografia que, dentre outras possibilidades, pode ser lida como um estudo da formação do desejo.

Quando, no início de 1930 - buscando uma fotografia da degolação de São João Batista para uma revista de arte na qual eu colaborava -, deparei-me por acaso com a reprodução de uma obra (aliás, muito conhecida) de Cranach, que se encontra na Galeria de Pintura de Dresden, Lucrécia e Judite nuas e dispostas simetricamente, foram bem menos as qualidades "finas e ligeiras" do pintor que me impressionaram do que o erotismo - para mim completamente extraordinário - com que estão nimbadas as duas figuras. (...) (LEIRIS, 2003, p. 55) 
Lucrécia, a personagem histórica de Roma do século V, símbolo da beleza que leva à tragédia e Judite, personagem bíblica, heroína que se vale da beleza e da sedução para vencer uma batalha, encabeçam a narrativa como alegorias que remeterão a um desfile de outras figuras femininas marcantes. $\mathrm{O}$ autor faz as suas referências emergirem como se as imagens que projeta em seu compêndio lhes tivessem sido dadas pelo acaso próprio do cotidiano. Como se tudo tivesse ido ao seu encontro e ele, na escritura do texto, tivesse a função de garantir uma ordem possível fazendo com que dela emanem sentidos e ele assim possa se compreender ou se revelar. Um traço marcante da prosa de Leiris em A idade viril é a facilidade com que desliza entre memórias e referências a escritores, artistas, dados históricos e pessoas de suas relações. A desmontagem ou a delação que faz de si vale-se da citação de seu repertório cultural. As alegorias e as personagens e imagens literárias a que recorre lhe permitem uma configuração de si e de seu contexto imediato.

Em "Da literatura como tauromaquia", escrito no Havre em 1945, o autor, marcado pela melancolia imposta pelo contexto da guerra, reflete sobre $A$ idade viril cuja escrita havia se iniciado e concluído bem antes da publicação, entre 1922 e 1935. Recupera a imagem do toureiro exposto ao perigo real dos chifres do touro para tecer considerações sobre quais riscos poderiam existir em se expor via literatura. Revelar-se sem censuras e sem o objetivo de provocar escândalos seria, talvez, uma forma de risco necessário e que não pode ser realizado sem uma forma estética, daí a imagem do confronto entre touro e toureiro das corridas espanholas, pois as mesmas possuem um “caráter escultural." Ou seja, o modo como o toureiro se expõe diante do touro segue formas estéticas bem elaboradas e que devem ser bem conduzidas.

Podemos pensar que Ruy Duarte de Carvalho nos expõe a uma espécie de radiografia de si confeccionada a partir de uma memória de leituras reconfigurada 
conforme os projetos de cada livro. Eis uma parte notável de sua poética. É interessante verificarmos que ler compõe o seu modo de estar no mundo e nele tomar parte (ou partido). Em cada livro o autor se revela a partir de um inventário de textos e lugares que fazem parte de suas experiências como cidadão, escritor e antropólogo. As geografias e os pensamentos que compõem seus livros são os do sujeito real que escolhe projetar ficcionalmente parcelas de si.

Sonia Miceli, em sua interessante dissertação de mestrado, Contar para vivê-lo, viver para cumpri-lo: autocolocação e construção do livro na trilogia ficcional de Ruy Duarte de Carvalho (2011), constata a importância das reflexões antropológicas para a construção ou instauração da subjetividade nos textos de Carvalho. O antropólogo angolano pode ser associado aos pesquisadores que na contemporaneidade dão relevo ao relato das experiências obtidas no trabalho de campo. Não desejando mais a construção de um relato supostamente objetivo, no qual as marcas reais das experiências proporcionadas pela viagem e pelos contatos com os sujeitos pesquisados são suprimidas. Na medida em que é eticamente necessário compreender que não é possível conceber um texto que totaliza a experiência do outro, se torna também necessária a estratégia da autocolocação. Segundo Miceli, a estratégia de compartilhar a voz, nos termos de Jean Roch, referência também trazida à tona por Miceli, garante ao texto uma estrutura não totalizadora na qual as vozes do pesquisador e dos pesquisados possam estar minimamente colocadas. O que nos levaria ao conceito de autoficção. Ao assumir sua subjetividade, o antropólogo projeta-se ficcionalmente na tessitura da narrativa.

\section{Os papeis do inglês: ode à viagem dos descomportados}

Em Os papeis do inglês, a intertextualidade fundamental se dá com o texto de Henrique Galvão. Segundo Carvalho, a narrativa do inglês que mata um parceiro, 
destrói tudo a sua volta, tenta se entregar e depois de algum tempo comete suicídio vem das páginas de Henrique Galvão. Mais especificamente, Em terra de Pretos, em edição de 1929. Informa Carvalho que "Galvão tem nessa altura pouco mais de trinta anos e fala de sua primeira viagem a Angola." (CARVALHO, 2007, p. 15) A crônica em questão tem o título de "O branco que odiava as brancas" e data de fevereiro de 1928.

Primeiramente, o inglês mata "um obscuro Grego", seu colega de profissão, pois são caçadores de elefantes. O caso teria ocorrido à beira do rio Kwango, em 1923, "do lado de Angola mas próximo da fronteira com o que é hoje território da Zâmbia”. (CARVALHO, 2007, p.15) Depois deste assassinato, o inglês procura por autoridades em um posto administrativo da colônia para que as devidas providências sejam tomadas. O chefe do posto registra a ocorrência, no entanto não irá se envolver num caso com cidadãos estrangeiros. O inglês volta para casa. Passam-se meses e nada acontece. Sir Perkings volta ao posto e mais uma vez deve retornar para casa. É neste ponto que o inglês, ao retornar, destrói tudo em seu acampamento e dispara um tiro contra seu peito.

Ruy Duarte menciona haver ao menos mais uma versão deste caso. Esta de Luiz Simões, um médico que andara pelas mesmas paragens na década de quarenta. Simões obteve informação com um funcionário administrativo que teria conhecido um Grego e um Inglês, desertores de exércitos. Soube ainda que o Inglês assassinara o Grego, atirara-se no Kwando e fora devorado por um jacaré.

No último parágrafo da primeira parte intitulada “A estória, a bem dizer", do Livro I, o autor reflete brevemente acerca das diferenças entre as versões. Entre a morte por jacaré e a morte por tiro da versão do Galvão bem pode haver intromissões dos narradores que as contaram. O narrador avalia que a opção de Galvão corresponderia à escolha por compor o perfil de um aristocrata. Também a motivação do crime 
corresponderia a esse perfil. O Grego teria feito insinuações a aversão que o inglês teria a mulheres brancas. O narrador anuncia que também irá introduzir perturbação e invenção em sua versão. No entanto, a quebra da ilusão narrativa não desfaz o encantamento, pois o leitor é convidado a firmar pacto com a ideia de que toda narrativa recontada, factual ou inteiramente imaginária, recebe contribuições de quem as conta novamente.

Na versão trazida a lume por Carvalho, um dos elementos que, certamente, tem conduzido as leituras críticas já efetuadas é a relação estabelecida com a antropologia ou, sendo mais específico, com os precursores da tradição antropológica inglesa. O Sir Perkings do texto de Galvão será o antropólogo Archibald Perkings. Amigo e admirador de Radcliff Brow, Perkings ficará desencantado com os rumos dados à ciência antropológica. Isso somado a um desencanto pessoal provocará mudanças incontornáveis em sua vida.

Para Diego Marques (2007), a história de Perkings pode ser considerada uma paródia do que se pode chamar romance colonial, obras produzidas no período colonial e que podem ser definidas por projetarem imagens reificadas das populações africanas. Tendo Ruy Duarte estabelecido o texto de Henrique Galvão, personagem controversa e um dos autores dessa narrativa colonial, como a base para as interlocuções construídas em Os papeis do inglês, seria possível compreendermos o romance como uma revisitação à textualidade de Galvão. Para Marques, Carvalho, ao mobilizar em seu texto referências como Galvão, Radcliff Braw, Conrad, Celine, dentre outros, realiza uma apreensão crítica de obras literárias que podem ser lidas como a evidência da ligação entre produção cultural e expansionismo europeu. No mesmo sentido caminha a dissertação Impérios desmitificados: Ruy Duarte de Carvalho e o passado colonial reescrito (2009), de Isabelita Maria Crosariol. Ao focar, particularmente, a 
intertextualidade estabelecida entre Os papeis do inglês e $O$ coração das trevas (1902), de Conrad e a crônica "O branco que odiava as brancas", de Galvão, busca compreender o modo como Carvalho lida com essas obras que podem ser consideradas símbolos da expansão imperial na medida em que representam o conquistador e a reificação dos conquistados. Conforme considera a pesquisadora, o fato de termos um autor angolano apropriando-se de narrativas europeias e recompondo-as na sua versão representa uma importante mudança, pois novos sentidos poderão ser conquistados a partir deste foco narrativo localizado na antiga colônia.

Não obstante a pertinência dessas leituras, optamos por enfatizar as ambiguidades dos escritores citados por Carvalho. São autores que fazem parte da formação do autor e a relação que possui com suas textualidades é profunda. Além disso, podemos compreender que os intertextos trazidos por Ruy Duarte, como Galvão, Conrad, Ferdinand Céline e Henry Michaux são símbolos da viagem e do cruzamento entre vida e texto. Nesse sentido, podem ser considerados como simbolizações que se comunicam com o saber e o fazer do antropólogo, pois também para este a viagem, o encontro ou o embate entre sujeitos e a escrita que procura refazer os sentidos das experiências obtidas constituem elementos que fundamentam a sua ciência.

Vejamos um trecho de Ruy Duarte acerca de Henrique Galvão:

De Henrique Galvão, nome que a minha geração já antes situava no passado, quanto mais agora a tua, lidei ao longo da minha infância com aquela parte das suas publicações que mais imediatamente se ligavam à paixão maior da sua vida, que era também a do meu pai, a caça. Do lugar que essa paixão terá tido na sua carreira de alto funcionário colonial ligado, sempre de muito perto, à ascensão e à queda do estado-novo português, quer a servi-lo quer a criar-lhe contrariedades, dirão os biógrafos e os historiadores. E tu sabes que não está para longe. Mas quando em 1961 se apossou do Sta. Maria, paramentado com uma boina preta, e andou a vagar com ele pelo Atlântico e a dizer que o ia trazer para Luanda mas depois apontou foi ao 
Recife, ao ouvir a notícia numa fazenda de café da região do Uíge, mais precisamente do Quitexe, onde então me achava, com 19 anos, a iniciar a minha vida de regente agrícola, mais do que deter-me na simultaneidade entre esse golpe e os ataques nacionalistas às prisões de Luanda, e a sublevação armada no Norte de Angola que me ia liquidando de pronto e afinal acabou mas foi por traçar-me o destino, o que me ocorreu foi que o herói dessa aventura era o autor daqueles quatro ou cinco volumes da Da Vida e da Morte dos Bichos e de outros dois, encadernados em imitação de veludo verde, A Caça no Império Português, que tamanho lugar terão também ocupado na configuração das minhas vocações. Nunca fui caçador mas mesmo assim. (CARVALHO, 2007, p. 26-27)

No excerto acima, podemos obervar a presença de um "tu", pois desde a dedicatória o leitor saberá que o livro possui uma destinatária "que se insinua e instala no texto" (CARVALHO, 2007, p. 7). O livro, como argumenta Miceli (2011), faz representar um diálogo que nos remete ao compartilhar experiências e narrativas, algo caro ao fazer do antropólogo Ruy Duarte, sempre interessado nas narrativas orais e nas composições identitárias do país que escolheu e sobre o qual empenhou suas reflexões. Ir ao encontro do outro e da voz do outro, sem deixar de expor a si mesmo marcou a sua produção intelectual e artística. No diálogo com esse "tu", que não deixa de representar cada leitor, o narrador e autor nos expõe a complexidade de seu universo. Ao mencionar o nome de Galvão, vem à tona a lembrança de seu pai, que também figura ficcionalizado na narrativa, pois na imaginação da trama os papeis do inglês se misturam a possíveis papeis de seu pai, o que resulta em mais uma simbolização da busca de si mesmo. Comenta o narrador autor que seu pai tinha na caça uma grande paixão, e que as publicações de Galvão em torno do assunto estavam presentes em sua infância. É inegável a relação afetiva demonstrada nesta breve memória, ao se lembrar do veludo e da cor verde dos volumes encadernados de Henrique Galvão, o autor confirmará que as obras ocupam um lugar em sua formação. 
Ainda que possamos ou devamos considerar as obras e autores citados por Carvalho como referências que remetem diretamente aos saberes do colonizador, não podemos e não devemos desconsiderar que há uma complexidade nessa seleção feita por Carvalho para compor as tramas de sua própria identidade enquanto escritor e intelectual angolano. Assim como as identidades das populações com as quais Carvalho entrou em contato são complexas, na medida em que estão inseridas em contextos marcados por drásticas interferências e transformações, também o autor narra e compartilha a complexidade de sua identidade. $\mathrm{O}$ intelectual angolano não pode negar a diversidade de influxos que agem sobre a sua formação e sobre a produção de sua consciência e de seus afetos.

As duas partes que compõe a narrativa, Livro 1 e Livro 2, além de possuir os trechos datados que sugerem a confecção de um diário de campo profundamente subjetivo, possui também entre elas um Intermezzo. Os livros estão, portanto, separados por um interlúdio como nas composições de música erudita.

O interlúdio que, dentre outros instrumentos, nos trará um duo de violino e kissange, com o inglês em seu violino e o cozinheiro, o Ganguela, passando de uma rabeca para o tyihumba e, finalmente, para o kissange no qual se sai melhor passando a tocar com o inglês.

Encontramos no Intermezzo uma espécie de sondagem psicológica da personagem capaz de explicar seu desatino e o seu ódio por mulheres brancas conforme relato de Henrique Galvão. Ao se envolver com uma ruiva americana de um grupo de passagem pelo acampamento foi remetido à sua infância e a uma visão de tórrida intimidade entre seu pai e uma amiga de sua mãe. A ruiva, uma mulher casada, com a qual se envolve passa a dizer, no momento do embate sexual que travaram, frases que 
evocam as da amante de seu pai e que vira e ouvira na "farm de sua infância, nas crepitantes margens do veld de uma Rodésia como a dos romances de Doris Lessing." (p. 118)

Tendo em vista a força poética e narrativa desse interlúdio, devemos considerálo de modo um pouco mais aprofundado.

Como já exposto o intermezzo é fundamental para a compreensão do romance Os papeis do inglês. Sua posição de centralidade no livro nos remete ao espelhamento entre os percursos de Archibald Perkings e o do próprio narrador. Ambos são antropólogos tendo que lidar com as dificuldades e os questionamentos advindos da disciplina científica que escolheram e, ao mesmo tempo, pressionados pelas circunstâncias de seu tempo.

O título interno, "Como num filme", nos remete diretamente para a relação do autor com a narrativa cinematográfica, como nos apontam as dissertações de Diego Marques (2007) e Sonia Miceli (2011). E, de fato, encontramos no intermezzo uma sequência que poderia servir de roteiro para a confecção de um filme. As imagens são fortes, cuidadosamente compostas e possuidoras de múltiplos significados. São composições alegóricas cujos significados vão além da obra em questão.

Vejamos em detalhe a primeira parte:

Toca violino. O inglês toca violino, de tempos a tempos e ao cair da tarde. Repete quase sempre séries infindáveis de frases musicais, vira a pauta, ensaia um trecho à frente, raramente executa uma qualquer apreciável extensão de música. Vivaldi muitas vezes, frase após frase, metade de frase, nota só gritante e depois silêncio. (CARVALHO, 2007, p.77) 
Assim tem-se início "O Intermezzo". Com este violino rarefeito que, muitas vezes, percorre as frases musicais de Vivaldi. Elementos da cultua europeia que o Inglês levara consigo. A narrativa segue com a aparição do cozinheiro que o acompanhará musicalmente quando estiver na posse do instrumento adequado. Vejamos:

O fenômeno insinuou-se de forma subtil. O Ganguela, cozinheiro e carreiro do coice, calado sempre, passou a vir agachar-se aos pés do Inglês, quase encostado às pernas altas do branco. Da primeira vez veio com uma caixa de madeira, espécie também de rabeca, aparelhada em peças cortadas à catana. Esperou uma das pausas, fez o gesto mas deteve-se, deixou passar mais três ou quatro, e imediatamente a seguir à que lhe trouxe a coragem, plangeu um som de sua lavra. Ninguém reagiu. O Grego, à distancia, meio de esguelha, voltou a cabeça e imobilizou-se tenso. O Inglês deu dessa vez mais tempo a pausa, trocou a perna em que apoiava o corpo e assim negou encosto ao ombro do Ganguela. (CARVALHO, 2007, p. 78)

Vemos que nessa primeira ocasião os músicos não se encontram. O Inglês não apenas interrompe o seu som, como também retira o apoio cedido ao cozinheiro pelo posicionamento de suas pernas. $\mathrm{O}$ instrumento que toca pode nos remeter à cultura portuguesa, mas, de fato, está presente em várias partes do mundo. $\mathrm{O}$ interessante em relação ao texto é percebermos a oposição entre violino e rabeca, já que há a sugestão de que o instrumento musical do Ganguela teria uma feitura mais rústica quando comparado ao do Inglês. Interessante também se faz notar a posição de subalternidade do cozinheiro escorado nas pernas do Inglês.

Da vez seguinte o Ganguela arriscou uma tyihumba, instrumento com as cordas agarradas a hastes curvas por cima da caixa. A intervenção foi desta vez mais generosa, dedilhada e contínua, e prometia se o Inglês não tivesse desencaixado o violino da pressão do queixo e alongado os braços quando olhou para baixo, na direcção do nariz do Ganguela, que pestanejou e rematou o acorde. E mais de meia hora ainda ali ficaram os dois, até que o branco lhe passou o violino para a mão e acenou que recolhesse o resto também. E ficou em pé no meio do terreiro, a 
vê-lo entrar na tenda com a tyihumba, a estante e o violino numa das mãos e o papel na outra, a olhar para a música, a caminhar às cegas, absorto no mistério dos sinais da pauta. (CARVALHO, 2007, p. 78)

Nesse ponto o dueto de estabelece. A falha do Inglês é o que promove a interrupção. O fato de o cozinheiro ficar "absorto no mistério dos sinais da pauta", nos faz pensar no modo como a personagem, ainda que subalterna, procura por meio da música as possibilidades de encontro e diálogo.

Da terceira vez, finalmente, foi de kissange que o Ganguela se apresentou, um desses kissanges dos mais completos, com caixa grande de cabaça antiga. Tomou a posição habitual, ensaiou o tom já na primeira pausa, verteu no ar o choro das palhetas, prolongou a escorrência, deteve o fluxo com um remate brusco. O Inglês endireitou o corpo, firmou-se com força na perna esquerda para dar melhor apoio ao ombro do Ganguela, fixou-se na pauta e rasgou as horas, crepusculares, mornas ainda, do fim da tarde nos confins do Kwando. (CARVALHO, 2007, p. 79)

Na terceira vez, o cozinheiro se valeu de um kissange e também aí o diálogo musical se tornou mais possível quando comparado ao uso da rabeca, instrumento mais próximo ao violino. Vemos assim o quão importante se faz a diferença, é ela que permite que os músicos se encontrem e toquem. Os instrumentos de percussão mais comuns ao território angolano se transformam na moeda de troca utilizada pelo cozinheiro para que o Inglês passe a vir ao seu encontro para acompanhá-lo em seus solos de kissange, como podemos ler na sequência imediata da narrativa.

Uma importante alteração ao programa viria dar-se, na estação seguinte, o Inglês passou a vir acompanhar, na sanzala, os solos de kissange do Ganguela, surdina morosa em noites de lua e frias, e nos intervalos de alguns trechos mais sentidos era o lancinante contraponto do stradivarius que vinha dilacerar o peito de tantos homens, de tanta raça e tão sós. (CARVALHO, 2007, p. 79) 
A beleza do início desse intermezzo é extraordinária. Pois temos o encontro da diversidade musical a representar a possibilidade do encontro e do diálogo entre as culturas e entre os homens. Nesse sentido, concordamos com Anita Moraes quando ao analisar o romance comparando-o com Nove noites de Bernardo Carvalho, nos diz que "fragmentos musicais europeus e africanos" estarão entrelaçados em novas composições. (MORAES, 2012, p. 169) A música faz mudar as posições entre o Inglês e cozinheiro que, a princípio, tem o apoio sobre as pernas do outro negado, depois tem o mesmo apoio oferecido e por último o Inglês é que se dirige ao encontro do kissange do outro. Vemos acontecer uma sequência cinematográfica em que as cenas são descritas não em riqueza de detalhes no sentido da extensão, mas em riqueza de sutilezas que intensificam os sentidos pretendidos pela alegoria. $\mathrm{O}$ autor compõe uma representação via encontro musical de uma fantástica mudança de paradigma em que o kissange passa o ser o condutor dos encontros culturais e musicais. Quando pensamos no modo como o Ganguela conduz essa mudança de paradigma, somos imediatamente levados ao terceiro livro que compõe a trilogia do qual Os papeis do inglês é a primeira parte, A terceira metade. As características da personagem nos permitem associá-la a Trindade, o protagonista do terceiro romance. Isso nos permite compreender o porquê de sua presença no título estendido do livro e ausente na capa, Os papeis do inglês ou o Ganguela do Coice; embora nesse, o cozinheiro seja um coadjuvante, no terceiro ele será a espinha dorsal do romance. É possível supor que o projeto da trilogia já estivesse delimitado quando Ruy Duarte de Carvalho fez publicar a narrativa do antropólogo que se cafrealiza, Archibal Perkings. O cozinheiro Trindade atravessa os dois primeiros romances para encontrar sua vida plena no terceiro, aquele que o autor diz querer dedicar a um protagonista negro e africano, já que o primeiro possui um protagonista branco e o segundo, um mulato, ambos com origens europeias. Embora Severo de As 
paisagens propícias possua mãe africana, seu pai é português. De todo modo, vale frisar que todos se encontram divididos entre universos distintos.

O modo como a personagem do cozinheiro, que é frequentemente chamado de Ganguela (nome atribuído a uma etnia de Angola) e o Inglês se relacionam em $O s$ papeis do inglês nos remete diretamente para as posturas de Trindade promovendo uma identificação entre elas. O interessante é compreendermos como a postura do Ganguela, que não é símbolo nem da revolta nem da pura acomodação, nos leva a pensarmos também na postura de Trindade, do qual podemos dizer o mesmo. Trindade busca o modo de ajustar-se numa sociedade fraturada obtendo o máximo de recursos que encontra disponíveis em seu contexto imediato, como veremos mais adiante. Essa mesma compreensão podemos ter quando analisamos a conduta do cozinheiro no início do "Intermezzo". Ele procura ir ao encontro da figura do estrangeiro, a princípio, utilizando um instrumento que, embora mais rústico, está mais próximo do violino do inglês, depois transita para o uso de instrumentos musicais pertencentes à tradição das culturas de seu território, promovendo uma sutil e profunda mudança de paradigma como podemos verificar na sequenciação do roteiro que o autor nos oferece.

Voltando ao conteúdo da narrativa, leremos uma descrição objetiva do espaço. Após a alegoria do encontro musical, temos uma câmera a nos traduzir os elementos essenciais do espaço. Vemos a lona armada protegendo "uma tenda menor e fechada" e, de acordo com a descrição, essa lona em duas águas possui uma grande área forrada com tapete de boa qualidade e forma um "prisma triangular deitado na horizontal de topos abertos". (CARVALHO, 2007, p. 79). A seguir veremos o local de dormir do antropólogo, o armário de suas seis espingardas, e a escrivaninha para a leitura de sua "escassa biblioteca". Apenas poesia isabelina, as obras completas de Shakespeare e uma bíblia. Vemos que o autor compõe cuidadosamente e por meio de uma elegante escrita 
metonímica a imagem do explorador cientista. Archibal Perkings ou os elementos utilizados na composição da personagem representam, sobretudo, o saber estrangeiro presente em terras africanas. Perkings, nessa narrativa, é composto principalmente por sua relação com a música e a literatura. Elementos com os quais a figura do Ganguela dialoga. A personagem não é avessa à cultura estrangeira representada metonimicamente na narrativa, pelo contrário, sua possibilidade de não subalternidade resulta de sua capacidade de mover-se em direção ao que lhe é estrangeiro vivenciando certa diversidade de experiências.

A próxima cena é uma preparação carregada de erotismo para o que virá a seguir, ou seja, a cena de sexo violento com a americana, que se torna o disparo deflagrador das violências que o protagonista cometerá, o assassinato do grego, a morte dos animais e a sua própria.

Deixou-se tombar sobre o catre rijo quando se preparava para descalçar as botas. Elevou apenas uma das pernas e deixoua em repouso alinhada pelo tronco deitado. A outra ficou dobrada, o pé assente no chão. Está imobilizado com as mãos sob a nuca e olha o tecto da tenda. Recebe na face e no peito a agitação fluida que os dois fogos projectam por toda a parte e as superfícies devolvem umas às outras. Arde sem dúvida na febre que lhe invadiu as horas. Tem uma arma a seu lado, com um projéctil na câmara, e essa é a única referência precisa que lhe ocorre, a par da obcessiva imagem da ruiva americana tal como se deu a ver ao longo de todo o dia. (CARVALHO, 2007, p. 81)

Vejamos um trecho do início da próxima cena:

A Americana surge enquadrada no triângulo da entrada da tenda que dá para o terreiro. O Inglês não pode saber há quanto tempo ela lá está porque não a vê chegar. Quando desvia os olhos do tecto da barraca em que esteve absorto, dá conta que ela está ali de pé, a fazer parte do quadro, integrada no resto pela ebulição dos efeitos da sombra e da luz. A face anterior do corpo, a própria face, está aureolada pelo brilho da rectaguarda, a massa dos cabelos é uma sarça ardente e dir-se-ia ser ela mesma a fonte da luz que intermitentemente lhe ilumina a 
depressão das pálpebras, a proeminência das maçãs do rosto e o volume perfeitamente talhado e firme da boca unida. (...) (CARVALHO, 2007, p. 81)

Em Ruy Duarte, a descrição dos elementos de cena é precisa e não dispensa a poesia. Lemos a poesia do texto e imediatamente compomos a poética visual que nos é oferecida. Um cineasta que se aventurasse na realização desse roteiro encontraria indicações claras a ser seguidas para a composição do filme. $\mathrm{O}$ autor se comporta como um diretor de cena oferecendo o essencial da imagem. Nas duas cenas acima, o leitor pode vislumbrar toda a tensão erótica do momento a partir de poucos e expressivos detalhes. Na cena em que o antropólogo está em sua tenda temos: o corpo meio vestido, a posição das pernas, uma esticada e a outra dobrada com o pé no chão, a agitação dos fogos, o pensamento dividido entre a arma e a americana ruiva. Mente e corpo estão indecisos e divididos entre opostos. A descrição da posição de seu corpo e com a arma ao lado anuncia a forte tensão que se seguirá entre sexo e violência.

$\mathrm{Na}$ cena seguinte temos o surgimento da americana como uma verdadeira aparição. Ela surge no prisma triangular da entrada da tenda com uma luz vinda detrás como se a mesma fosse projetada de si. O destaque está em seus cabelos identificados como uma sarça ardente, a câmera caminha pelas pálpebras, maçãs do rosto e boca, e depois pela brancura da camisa permitindo que se veja "o volume diminuto mas agressivo do peito" , os pés nus; enfim, em termos gerais, há uma descrição que nos encaminha para uma figura feminina representada como mistura de delicadeza e força destrutiva. A americana ruiva surge na obra como surgem as figuras femininas em Michel Leiris. A cena de sexo e violência que se seguirá condiz com as descrições efetuadas, a ambiguidade da americana ruiva fica bem marcada nos cabelos de sarça ardente e no peito diminuto mas agressivo. 
Com o desfecho do embate sexual vemos a americana estirada no chão sendo, logo a seguir, acompanhada pelo Grego e por outra personagem, um conde que acompanhava o grupo, de volta à sua barraca e ao seu marido. $\mathrm{O}$ autor nos encaminha então para uma digressão a partir da qual compreenderemos a experiência traumática que está na memória da personagem e, cuja lembrança, atua como o gatilho que faz disparar num violento jato único as derrotas e as amarguras de uma vida. Vemos irromper o ódio ao pai, a decepção com a ciência, a traição de sua mulher e o ódio às ações de espoliação por parte do Grego que será assassinado. A beleza que a narrativa nos revela está na visão totalizadora do sujeito, não há uma separação entre questões que poderiam ser tomadas como sociais daquelas que seriam propriamente individuais.

$\mathrm{Na}$ digressão acompanhamos a narrativa de um episódio da infância de Archibald. Na propriedade rural da família, Archibald surpreende seu pai traindo sua mãe com uma amiga desta no estábulo.

(...) O mundo das mulheres é para si, e sê-lo-á daí para frente até quase o fim da vida, um domínio de insondável substância, inacessível a qualquer verdadeiro tacto. A mãe borda, Archibald conhece todos os pontos de bordado que a mãe faz e nesse momento ela abre um "à jour" em linho à maneira da Irlanda do Sul. A amiga não faz nada e só conversa, sentada de lado no canapé. Veste calças de montar e botas altas e, perturbação limite, uma camisa imaculadamente branca, aberta no peito, tão vasta para o seu torso frágil que dir-se-ia esvoaçarlhe à volta. Apenas o peitilho vem aderir-lhe ao corpo, e o peso do tecido revela os seios que quase não tem, à solta por baixo, adivinha-o ele e adivinha-o o pai quando estão à mesa e os olhares de ambos convergem para lá e depois se encontram e Archibald cora e confunde os gestos. O seu cabelo é ruivo, abundante e frizado, preso com um grampo à altura da nuca. Algumas mechas caem-lhe para o rosto. É esse rosto de anjo que derrota Archibald e lhe perturba em extremo as emoções, beata contemplação votada à exaltação da invenção dos seios nus. (CARVALHO, 2007, p. 85) 
Como podemos ler, pai e filho tem o desejo despertado por uma mesma mulher. Como já sabemos, o resultado disso marcará indelevelmente as experiências de Archibald Perkings. Toda a vida da personagem será marcada por uma sucessão de traições: a traição de seu pai, a daquela que motivou os seus primeiros desejos, ainda que ela não soubesse, a traição de seus companheiros de ofício, a traição de sua mulher e, finalmente, a traição do Grego. O episódio com a ruiva americana faz deflagrar toda uma vida de desajustes cujo símbolo tornado evidente fora a imagem de seu pai e o gesto de fúria que cometera após o episódio. Nesse mesmo dia, o menino em posse de uma arma "abate, inexoravelmente, uma a uma, todas as capotas, e as galinhas, e os patos, e o casal de pavões, que o ímpeto de sua fúria impede de se lançarem para além da cerca." (CARVALHO, 2007, p. 89) Vemos que há um espelhamento do gesto tresloucado. O gesto do passado é repetido e finalizado com o suicídio.

A estratégia utilizada por Carvalho para compor a sua versão do homem que odiava mulheres brancas do texto de Henrique Galvão, coloca em cena um sujeito de enorme complexidade. Referências históricas, particularmente da história da antropologia, se misturam aos traumas vividos pela personagem. A intrigante particularização de seu percurso permite que o leitor desautomatize o olhar para encontrar-se com os problemas e as dificuldades desse antropólogo, ainda que paire sobre ele as suspeições que recaem sobre a sua ciência, muitas vezes posta a serviço da colonização.

O interlúdio nos traz a chave de interpretação para compreendermos o desatino de Archibald Perkings. O autor retorna à infância da personagem e nela localiza um trauma não superado. A isso se soma a profunda decepção que o domina quando toma consciência de que o Grego estava destruindo artefatos arqueológicos, provavelmente em busca de tesouros perdidos. Eles haviam encontrado ruínas talvez pertencentes a um 
conjunto maior do qual fariam parte os amuralhados do Zimbabwé. Perkings que já havia se rebelado contra certas inflexões da antropologia, ao se deparar com a situação se dá conta do quanto já pode haver de perdas para o conhecimento das histórias, dos territórios e dos homens.

(...) A raiva era a que não poderia deixar de ocorrer a Archibald Perkings, antropólogo distinto, discípulo de Frazer e condiscípulo de Radcliff-Brown, perante a monumentalidade de uma barbárie como a daquela demolição que se exibia agora à sua frente. (...) (CARVALHO, 2007, p. 125)

A referência a Frazer e Radcliff-Brown, dois nomes fundamentais da antropologia inglesa, nos permite interpretar que, embora Perkings tenha rejeitado a ciência por ver nela "braços" e "olhos" do império, ainda assim resiste a ligação com o pensamento antropológico e seus fundadores. Abandonar a ciência enquanto prática circunscrita a uma realidade socioeconômica não será abandoná-la enquanto legado cultural ou exercício do pensar.

A partir da trajetória de Archibal Perkings e dos intertextos que há no romance, podemos dizer que em Os papeis do inglês há uma espécie de ode à desobediência, aos comportamentos não convencionais. São muitas as viagens dos descomportados. A começar pelo próprio Henrique Galvão e o episódio do Santa Maria. A ele podemos juntar os nomes do falsário Alves dos Reis, de Conrad, de Henri Micheaux, de Céline e do Marquês de Sade. Todos eles presentes na obra, podem ser tomados como figuras geradoras de um coro de vozes que ressonam a ideia central, ou seja, a compreensão de que os sujeitos podem conduzir-se por uma fidelidade ao que a experiência lhes indica. Uma passagem rápida pelas biografias desses homens nos revela que a noção de experiência está diretamente associada ao viajar. O deslocamento físico é compreendido pelo autor como um exercício necessário à formação. O coro reunido em sua obra nos proporciona o entendimento de que o embate de um sujeito com o outro e em território 
estrangeiro é uma imagem forte que ultrapassa Os papeis do inglês e extravasa para o conjunto da obra.

Alves dos Reis, que tem sua estória contada no romance, é citado como um "genial falsário", aquele "que no seio das finanças portuguesas operou uma das maiores burlas da história da finança universal." (CARVALHO, 2007, p. 63) Obteve fortuna entre Portugal e Angola executando inúmeras falsificações, de diploma às notas de moeda, dando dribles extraordinários na racionalidade de sistemas jurídicos e financeiros. Marquês de Sade, aristocrata francês do século XVIII, o escritor e dramaturgo foi um grande desafiador de convenções morais e na prisão escreveu muitas de suas obras. Certamente, sua vida e obras escapam a enquadramentos e definições. Céline, médico e escritor francês, foi um viajante que aportou em vários lugares do mundo a serviço da Liga das Nações. Além disso, conheceu a notoriedade por conta de sua obra literária, da qual Carvalho destaca Viagem ao fim da noite (1932), e viveu a decadência e o isolamento em decorrência de seus posicionamentos políticos. Henri Michaux, poeta e pintor belga, viajou pelas Américas como fogueiro de um navio mercante e foi autor de diários de viagens reais e imaginárias. Autor de muitas obras devotadas ao mar e marinheiros, o escritor britânico de origem polaca, Joseph Conrad, também foi marinheiro. O interessante Coração das trevas (1902) possui uma estrutura de narrativa dentro da narrativa, a aventura vivida em África pela personagem Marlow está sendo contada por ele a um grupo de marinheiros em viagem e o leitor acompanha a narrativa elaborada pela personagem.

Celine, Conrad e Michaux são referências para Carvalho de vidas e experiências conquistadas no deslocamento, no embate entre homens e espaços. Possuem também a particularidade de terem composto obras atravessadas por influxos autobiográficos. São escritas de grande envergadura elaboradas por homens cujas biografias estão marcadas 
pela viagem e pela aventura que levam a inquietações e a comportamentos ou ideias fora das convenções de seus contextos. O coro dos descomportados, no qual entra a voz de Michel Leiris, também citado em Os papeis do inglês, nos faz pensar na posição privilegiada que as leituras de autores de língua francesa ocupam na produção intelectual de Ruy Duarte de Carvalho.

(...) E desencantei no meio do resto, com gosto, um livrinho que depois lhe dei e era uma espécie de legado, os Cinq Études d'Ethnologie de Michel Leiris, que há mais de vinte anos tinham vindo também ao meu encontro e agora, numa edição diferente mas igualmente de bolso, trazia ali nem sabia bem porquê ou talvez começasse a perceber... (CARVALHO, 2007, p. 142)

Em Os papeis do inglês há duas narrativas que se entrelaçam e se espelham. A narrativa de Archibal Perkings e a do próprio narrador, persona ficcionalizada que nos remete ao próprio autor em sua busca por escritos que pertenceram ao inglês e teriam se perdido. Interessa-nos mais a vida do inglês construída nessa trama desenvolvida pelo narrador. Nela centramos nossa abordagem do romance. No trecho acima, a obra de Leiris, considerada um legado, é entregue a uma amiga da sobrinha de um primo do narrador, grupo que o acompanhou numa parte de sua viagem em busca dos papeis por territórios que pertencem a um contínuo que liga o sul de Angola ao norte da Namíbia.

Como já assinalamos, podemos encontrar em Leiris uma referência importante para Carvalho, seja no estilo e na variação dos gêneros textuais que as obras de ambos abrigam, seja nas proposições que alimentaram suas visões intelectuais. Ambos possuem uma prosa poética marcada pela citação de repertórios formativos e pela expressão de subjetividades que colocam vários de seus textos numa região indefinida entre o ensaio, a autobiografia e a ficção. Ambos encontraram na autorreflexão uma inegável força intelectual. Suas obras são marcadas pela proposição de que o olhar para o outro deve ir acompanhado de um olhar para si, na tentativa de expor os limites de 
quem olha. A antropologia que podemos apreender de Ruy Duarte e Michel Leiris considera o presente dos sujeitos em interação, daí as ideias, já mencionadas de Leiris, quanto ao trabalho do etnógrafo que não pode ignorar que a etnografia nasceu ligada à colonização.

Além disso, o episódio acima nos remete ao que podemos chamar de convite à leitura efetuado por Carvalho. O autor convida o leitor a visitar o seu quadro de referências intelectuais e afetivas, ele nos disponibiliza a sua biblioteca, assim como faz com a personagem do romance. Temos aí, nesse gesto simples, uma ótima representação da poética de Carvalho.

Devemos, no entanto, voltar ainda ao descomportado Galvão cuja narrativa sobre certo inglês serviu de mote para a criação de Archibal Perkings, símbolo de uma antropologia que não pode se comportar.

Henrique Galvão foi um militar português e um entusiasta do governo de Salazar, conhecido por protagonizar um plano audacioso de tentativa de desestabilização de seu poder. Em 1961, participa do assalto e do desvio do navio Santa Maria pertencente à Companhia Colonial de Navegação.

Nas páginas iniciais de sua narrativa, Carvalho se refere a Galvão como "fascinante personagem da nossa história comum, o muito activo e irrequieto capitão." A seguir, proporá que o oficial português rematou sua carreira política inaugurando "a prática moderna da pirataria política”. (CARVALHO, 2007, p. 12) Sem dúvida, o autor nutre uma simpatia pela personagem histórica, na medida em que o seu gesto não só representou abalos para o governo português, como também do ponto de vista simbólico representa o caráter obstinado, que se doa integralmente às suas experiências e que 
busca criar as possibilidades de intervenção numa dada realidade com as estratégias disponíveis.

Archibal Perkings tem o seu percurso igualmente marcado por obstinações e desejos de mudança que podem seguir por caminhos irregulares ou surpreendentes. Seja como for, a consciência de si e de seus valores se aprofunda. Ruy Duarte de Carvalho nos apresenta personagens que se constituem nas contradições do próprio existir. $\mathrm{O}$ militar salazarista que se torna opositor de Salazar e o antropólogo que se opõe a uma antropologia a funcionar como os olhos do império possuem em comum a capacidade do interrogar-se, do ver-se a si mesmo diante do que se apresenta e refazer os caminhos em nome de uma crença ou de valor ou de uma consciência.

\section{As paisagens propícias: diálogos com o passado}

Em As paisagens propícias, o mesmo narrador segue em busca pelo "branco das namíbias”. Não serão mais papeis, mas um autor de papeis encontrados anteriormente a ser buscado. A demanda do narrador que funciona como pretexto segue seu curso e o leitor também segue acompanhando o extenso quadro de referências do autor ao seguilo nesta busca por papeis e autores como se fossem tesouros antigos. Severo, o protagonista dessa narrativa, é a quem o narrador procura para resolver suas inquietações em relação aos papeis encontrados e que constituíam a demanda do livro anterior. No entanto, a relação com Severo, a partir dos encontros e de uma inesperada troca de emails, será utilizada pelo autor para que o leitor entre em contato com paisagens, lugares e dados culturais, além de variadas referências literárias.

Embora Severo tenha nascido na Gabela, filho de português com uma jovem negra, ele passou a primeira infância em Portugal na companhia do pai que havia regressado para sua terra natal. No final de sua infância retornam para que o pai refaça a 
vida no continente. Sua mãe morreu quando ele nasceu. A personagem, que pode ser definida como um desencaixado ou um descomportado, encontra o seu caminho por descaminhos. As viagens do agrimensor são também as viagens de um sujeito envolvido em contrabandos. De todo modo, como assinala o narrador, para "SRO ia inaugurar-se, ali, uma busca da sua mãe, ou daquilo que uma mãe que é negra pode metaforizar, destinada a nunca mais o largar pela vida inteira." (CARVALHO, 2005, p. 52)

Do que SRO não teria dúvida nenhuma (com tanta migração e com tanta convergência, antiga e recente, para aquele buraco de deserto à volta, a que ele agora se vinha adicionar), era de que se achava em pleno numa região de fronteira, tanto mais que até Kuvales e himbas que por ali encontrava eram em muitos casos sujeitos banidos dos núcleos duros das sociedades donde provinham por infracção de tabus graves quase sempre ligados a relações com grupos caçadoresrecolectores. Fronteira, entendida assim, é isso, são áreas intersticiais entre sociedades organizadas, abertas à intrusão e à instalação, onde podem acolher-se os que vêm de longe e têm de encontrar lugar, os banidos e os derrotados, os que os desdobramentos grupais, as fomes e as sobrecargas das pastagens empurram para uma no man's land, quase sempre ainda assim habitado por alguma espécie de aborígenes (bosquímanos, quer dizer, mukankalas, no nosso caso). (...) Há uma produção sistemática de frontiersmen. De homens de fronteira, dizem os estudiosos. E SRO, mulato já de si, resultante colonial, portanto, de processos de fronteira também, inscrito agora, em absoluto, na configuração de uma absoluta no man's land, destinado pois ao exercício de uma dinâmica encapsulada de relações, eis que se vê por fim, assim, homem mesmo de fronteira, em condição e glória (CARVALHO, 2005, p. 163-164)

$\mathrm{Na}$ direção do sul e de suas origens, Severo irá se deparar com homens de fronteira, assim como ele. Vemos que Ruy Duarte se interessa por processos de transformação e redefinição identitária para além da sociedade colonial, mas que, de algum modo, também podem ser acionados por ela. Severo é, como diz o narrador, uma 
"resultante colonial", e que se defrontará com outras situações de fronteira ou de processos de formação e constituição de identidades.

Deixando de lado os descaminhos de Severo, vamos acompanhar o diálogo do autor com duas referências que surgem como emblemáticas no romance e que nos possibilitará compreender o diálogo de Ruy Duarte com discussões intelectuais contemporâneas. Nesse aspecto, desejamos nos aproximar de seu pensamento enquanto intelectual que se faz presente em seu romance.

Do romance As paisagens propícias (2005) destacaremos dois viajantes, um missionário que empreendeu sua viagens no século XIX; o segundo, um neto de missionário da primeira metade do século XX: Padre Carlos Duparquet, autor dos textos reunidos em Viagens na Cimbebásia e Carl Hugo Linsingen Hahn, nome que "talvez seja hoje sobretudo referido como fotógrafo colonial”. (CARVALHO, 2005, p. 121)

O livro de Pe. Carlos Duparquet, Viagens na Cimbebásia, textos traduzidos e organizados por Gastão de Sousa Dias e publicados pelo Museu de Angola em 1953, é muito interessante por nos trazer relatos que dão conta tanto das paisagens encontradas quanto das populações e das relações destas com as operações do sistema colonial português. Já no início de um primeiro relato podemos ler:

Foi a 13 de dezembro de 1866 que deixei Moçâmedes para me dirigir para o interior do país. Alguns dias antes haviam chegado como prisioneiros a Moçâmedes, três sobas das seguintes regiões: Vangé, soba da Huíla; Amaribariba, da Quihita; e Binga, dos Gambos. (DUPARQUET, 1953, p. 57)

Os soldados que os tinham acompanhado, regressavam aos respectivos fortes. Era para mim uma excelente ocasião que a Providencia me oferecia, porque é perigoso atravessar o deserto sem uma escolta suficiente, tanto por causa dos selvagens Mandombes, que massacram os viajantes isolados, como por causa do grande número de leões que infestam estas montanhas. (DUPARQUET, 1953, p. 58) 
O texto traz uma nota de rodapé declarando que Portugal permitia que as populações se governassem, porém mantinham seus chefes submetidos às autoridades portuguesas. Mais adiante nos depararemos com outras situações que para a leitura crítica de especialistas na área podem ser reveladoras do modo como o poder era exercido pelos colonizadores. Isso nos indica a importância dos textos dos viajantes como fontes que podem ser decisivas para os pesquisadores, particularmente, antropólogos e historiadores. Muito embora, as paisagens europeias se interponham como uma referência sempre recorrente, a clareza do texto e o prazer sincero diante do novo tornam a leitura agradável.

Existem entre os bois da região duas variedades muito interessantes: uma é desprovida de chifres, e a outra possui-os, mas não soldados aos ossos do crâneo, estando simplesmente ligados a pele e pendentes de cada lado da cabeça.

A maior parte dos vegetais da Europa desenvolve-se muito bem neste clima. Vi pessegueiros de dimensões e vigor bem superiores aos dos nossos pessegueiros da Europa. Algumas macieiras ali plantadas parecem dar-se bem. (...) (DUPARQUET, 1953, p. 63)

As paisagens propícias é um romance que pode ser tomado como um bom exemplo do que Edward Said, em Cultura e Imperialismo (1993), chama de viagem para dentro. Os autores das antigas colônias e agora novos países se veem diante do imperativo de rever histórias, tradições, geografias, identidades, etc. É preciso renomear o que foi nomeado arbitrariamente.

Carvalho imagina que poderia ser "um desses viajantes europeus que sobretudo no último quartel do século dezanove foram dando notícia ao mundo de como é que era a coisa por aqui". (CARVALHO, 2005, p.14) Assim, podemos reconhecer que se opera um refazer das viagens. As populações e as paisagens serão olhadas e consideradas por olhos cujo dono se impôs outra ordem de compromissos. E não mais 
olhos como os dos viajantes europeus que tratam os espaços como se os mesmos estivessem a espera da colonização. Contudo, devemos assinalar que tal perspectiva revisionista em Carvalho é construída com complexidade.

Para nos referirmos a um dado específico, em relação ao curso das águas, Carvalho registrará que o próprio missionário Duparquet já havia corrigido erros que cometera. "Depois de ter andado pelo norte o padre virá a perceber que as águas do Etosha vêm do Cuvelai, e não do Kunene" (...) (CARVALHO, 2005, p. 43) Duparquet cometera o erro numa primeira impressão e depois produzira a correção. Esse registro de Carvalho nos indica que as suas leituras cuidadosas caminham entre aproximações e afastamentos da obra do viajante. O autor nos demonstra que considerar a presença do olhar a serviço da colonização não pode significar o desprezo total à obra. As obras dos viajantes continuam a constituir uma fonte de pesquisa a ser autorizada ou desautorizada.

Quando Ruy Duarte considera as fotografias de Hahn, vemos o desenvolvimento da perspectiva do antropólogo angolano de modo mais claro.

Existem de facto uma semiótica e uma tipologia da paisagem. A paisagem como "off-shore", por um lado, e pelo outro como uma modalidade plena de códigos culturais, de visão das coisas. E os analistas estão certos. Mas até os próprios analistas se interrogam se o poder das fotografias de Hahn, sem dúvida reveladoras dos implícitos de um determinismo colonial explícito, não se deve afinal muito também, por mais que lhe custe reconhecer, talvez a uma qualidade pessoal sua, à sua sensibilidade de indivíduo. Pode ser uma estética aferida a objectivos administrativos e marcada por ideologias evidentes, mas há ali uma inequívoca capacidade para ver dentro da paisagem, para antecipar o disparo, para intuir os significados. Uma receptividade ao potencial do quadro, dizem alguns... Pelo que... (CARVALLHO, 2005, 124-125) 
O trecho acima constitui uma ótima ilustração do modo como o autor se relaciona com as obras constituídas no bojo da colonização. Ruy Duarte não exclui os possíveis diálogos com essas obras. Isso se torna evidente no exemplo do diálogo aberto com as fotografias de Carl Hugo Linsingen Hahn. Como diz Ruy Duarte, "há ali uma inequívoca capacidade para ver dentro da paisagem”. E também se torna evidente no diálogo com as descrições das paisagens trazidas pelo texto de Pe. Carlos Duparquet. Vejamos outro trecho de sua argumentação:

Ora para os analistas de hoje tudo isto corresponde, o produto e a adjectivação que o acompanha, a uma ideologização da paisagem à volta dos "wide, open spaces", solidão e isolamento, silêncio e vazio sem figuras. A um tempo arcaico e a um espaço sem tempo. Quer dizer, a uma lógica imperial centrada à volta da cultura e da história europeias de há dois séculos a esta parte, que é a da apropriação de terrenos e de espaços, inclusive através de uma produção visual, neste caso, porque há equivalentes na literatura - que dê resposta e expressão a um desejo incontido de expansão. (CARVALHO, 2005, p. 120)

Como o autor se refere aos "analistas de hoje" podemos tomar uma obra de grande repercussão e bastante lida nos meios acadêmicos voltados para os estudos africanos no Brasil. Estamos nos referindo ao trabalho de Mary Pratt em seu Os olhos do império: relatos de viagem e transculturação (1999).

Os olhos do império foi concebido dentro de um amplo desafio intelectual que se poderia chamar de descolonização do conhecimento, iniciado nos anos 60 pela desintegração da última onda de impérios coloniais europeus. (...) A descolonização do conhecimento inclui a tarefa de chegar a compreender os caminhos pelos quais o Ocidente (a) constrói seu conhecimento do mundo, alinhado às suas ambições econômicas e políticas, e (b) subjuga e absorve os conhecimentos e as capacidades de produção de conhecimento de outros. (PRATT, 1999, p. 15)

A definição, clara e concisa, utilizada por Pratt no prefácio à edição brasileira para explicar que os saberes ou as ciências e as artes produzidas nas sociedades dos colonizadores de nossa história mais recente podem ser vistos como associadas às 
ambições de poder e domínio. Assim sendo, tornam-se necessárias atitudes e análises pautadas pela revisão de conteúdos e práticas artísticas e científicas. As marcas da ideologia dos dominadores podem estar nos conceitos, nas linguagens, nas perspectivas teóricas, nas percepções compartilhadas das realidades, enfim, em todas as dimensões do fazer da cultura letrada.

Ainda que para Ruy Duarte de Carvalho essa atitude crítica seja necessária e ele a executa como lemos em seu texto e em seus diálogos com a textualidade construída por viajantes europeus, compreendemos que o autor a executa sem perder de vista a complexidade própria de toda e qualquer produção intelectual. O autor dialoga com obras compostas no contexto da colonização criticando-as, avaliando-as em seus vieses ideológicos e desejando considerá-las pertinentes quando a obra pode ser projetada para além das limitações ideológicas que, a princípio, a condenaria ao esquecimento.

Consideramos de grande interesse para esta parte nos aproximarmos um pouco mais do belo trabalho de Mary Pratt. Os olhos do império: relatos de viagem $e$ transculturação (1992) é uma importante contribuição para o pensamento sobre império e imperialismo entre os séculos XVIII e XIX. Os relatos de viagem que a autora analisa deflagram uma visão de mundo em curso, ou uma nova consciência planetária na sua formulação. As narrativas de navegação abrem espaço para as narrativas de conhecimento do interior dos territórios. Nada poderá mais fugir aos olhos dos impérios. Ao apreender e compreender este movimento, a autora nos demonstra a construção de um imperialismo que, sem dispensar a formação de impérios territoriais, vai além, pois é capaz de gerar discursos e práticas que opacificam a dominação. São discursos e práticas compreendidos por Pratt como "anticonquista". 
Se no nível da superfície eles se dão como exercício do conhecimento puro (catalogação de fauna e flora, conhecimento da geografia e dos tipos humanos, etc.), em camadas profundas, conforme a autora destece os fios das estratégias discursivas, verificamos que essas práticas e discursos são mais reveladoras do tipo de olhar que possui o viajante europeu do que do outro que este viajante encontra ao usurpar os caminhos. E nesse ponto se encaixam perfeitamente os trechos que destacamos dos relatos do missonário Pe. Duparquet quando se refere aos bois e às espécies frutíferas. Para os limites deste texto utilizaremos da parte 1 (Ciência e sentimento) o capítulo 3, "Narrando a anticonquista" e o capítulo 4 "Anticonquista II: a mística da reciprocidade". Conforme nos informa, seu objetivo não é efetuar uma análise exaustiva da literatura de viagem sobre a África meridional no período por ela considerado, mas "ilustrar o impacto discursivo da história natural e da nova consciência planetária". (PRATT, 1999, p.79) Vamos apresentar de forma esquemática e resumida alguns dos argumentos produzidos pela autora nas análises dos textos por ela selecionados.

O primeiro texto analisado no capítulo 3, A situação atual do Cabo da Boa Esperança (Alemanha, 1719), de Peter Kolb, em linhas gerais mantém as convenções da narrativa de navegação, ou seja, os percalços da viagem marítima estão bastante presentes no texto. Com relação aos contatos que estabelece, Kolb procura promover a humanização dos grupos com os quais se depara, os hotentotes. Segundo Pratt, embora ele rejeite práticas culturais destes povos, ele também "rejeita paradigmas de diferenças essenciais" (PRATT, 1999, p.87), ou seja, há níveis de interação que marcam o modo como Kolb representa o contato. De todo modo, Pratt frisa que não se trata de apresentar os hotentotes como iguais aos europeus, mas sim apresentar seres que 
cabem nas categorias europeias de análise, daí o interesse do autor pelas práticas do grupo.

Anders Sparrman, autor de Viagem ao Cabo da Boa Esperança (Suécia, 1775), e William Paterson, autor de Viagens na terra dos hotentotes e dos kaffirs (GrãBretanha, 1789) produziram textos plenamente identificados com as viagens científicas, ou seja, a exploração e o conhecimento de cada pedaço de território, exemplificando ainda mais o que a autora chama de consciência planetária. De acordo com sua apresentação ambos "organizam sua narrativa por meio do empreendimento cumulativo" (PRATT, 1999, p.98). São grandes observadores e documentadores do espaço, o que torna o universo humano ao redor não mais do que pano de fundo para os registros do naturalista e a sua composição de verdades atemporais.

No relato de viagem de John Barrow, Viagens ao interior da África Meridional (Grã-Bretanha, 1801), também predominam as descrições da natureza. No texto de Barrow, francamente relacionado à expansão imperial, há um tipo de objetividade que explicita a metáfora do título do livro de Mary Pratt. Mais do que dominar com "punhos de aço" ou "mãos de ferro", os impérios se projetam e se alargam com o olhar especializado. No texto de Barrow, algumas descrições vêm acompanhadas por um discurso explicativo. Assim a descrição de um lago salgado vem acompanhada por páginas em que se especula as origens do sal. Há um olho que vê além do visível e explicita o que vê. Este olhar especializado executa o exame das potencialidades de um território, como se o mesmo a ninguém mais pertencesse, como se sobre o mesmo não se articulassem comércios, culturas e vidas próprios. O olhar projeta um espaço livre e a espera do desenvolvimento, da colonização. (PRATT, 1999, p.114) 
No capítulo 4, "Anticonquista II: a mística da reciprocidade", Mary Pratt analisa Viagens nos distritos interiores da áfrica (1799), de Mungo Park. Possuidor de uma representação pautada pela negociação, o texto de Park apresenta o que a autora classifica como um herói sentimental. Trata-se de texto em que a união entre ciência e sentimento se torna ainda mais evidente na medida em que está centralizado no enunciador, no sujeito que escreve, perfazendo a dramatização de um "eu". Na medida em que Park investe na representação de trocas subjetivas, inclusive cedendo seu corpo para a curiosidade dos estrangeiros que encontra, nos deparamos com uma narrativa organizada pela ideia de reciprocidade.

Para Pratt “(...) a anticonquista 'subscreve' a apropriação colonial, mesmo quando rejeita a retórica, e provavelmente a prática, da conquista e subjugação". (PRATT, 1999, p.102) Com relação a Park, Pratt não nega que em seu texto há "possibilidades genuínas de autocrítica" (PRATT, 1999, p.152), no entanto, as ideologias europeias não são criticadas. Park se vê imbuído de uma missão civilizadora para a qual os obstáculos são os africanos, ou seja, os valores europeus enquadram a sua visão de tal forma que a reciprocidade não pode ser concretizada.

A literatura de Ruy Duarte e, particularmente, os trechos assinalados de As paisagens propícias, deixa claro que o autor não é alheio às análises empreendidas por intelectuais dedicados a "descolonização dos saberes" no sentido utilizado por Mary Pratt. No entanto, cabe frisar que para Carvalho os diálogos com a tradição de obras compostas ainda sob o domínio colonial se dá entre aproximações e afastamentos. Como já apresentamos no capítulo anterior, ao comentarmos a poesia de Ondula savana branca, o autor se orienta por um movimento pendular aos trabalhos 
produzidos no bojo da colonização. Seu gesto constitui um convite ao olhar cuidadoso e à autocrítica permanente.

Para o autor as paisagens registradas por Hahn ainda que sejam "marcadas por uma ideologia evidente", possuem "uma inequívoca capacidade para ver dentro da paisagem". O que significa dizer que o que ele vê de arte nesse trabalho, não poderá ser desconsiderado, ainda que a partir das imagens possam ser vislumbrados projetos coloniais não enunciados no plano de um discurso direto. Ou para utilizarmos a expressão, muito apropriada, de Mary Pratt, discursos que constituem uma extensão dos "olhos do império" mesmo quando seus articuladores não estão diretamente envolvidos com o sistema colonial. Mesmo quando os mesmos propõem um discurso de apoio e não de subjugação.

\section{A terceira metade: viagem ao humano}

O terceiro romance, A terceira metade, nos encaminha para uma viagem ao humano. $\mathrm{O}$ narrador coloca-se em busca não mais de papeis, mas de fitas cassetes que conteriam rezas gravadas por um tio de Severo, a personagem principal do romance anterior. Em sua busca veremos que o autor nos encaminha de fato para as contradições profundamente humanas que habitam o coração do protagonista.

Das páginas de A terceira metade somos levados com o mesmo entusiasmo de sua personagem central, Trindade, para as páginas de As aventuras de Hucleberry Finn, de Mark Twain. A apresentação do livro lhe é feita por um engenheiro texano que estava hospedado no hotel em que Trindade trabalhava. 
ora esse engenheiro um dia chamou-lhe andava ele a cirandar por entre as mesas do vasto salão de jantar à hora do mata-bicho com um prato de salsichas fritas na mão, para dizer-lhe muito imprevisivelmente que se o Hucleberry Finn fosse negro e ele, Trindade, usasse chapéu de palha, dos dois daria para urdir um personagem só, de aspecto, e às tantas até mesmo de caráter, porque emanava de ambos uma energia primeira, inédita, e um programa de devir que a história não alcançava ........ uma conversa assim talvez nem o Trindade a entendesse, e nem às tantas o próprio engenheiro, mas sobre a toalha da mesa, aberto, estava pousado um livro com a capa virada para cima e dela o Trindade reteve num relance o que lhe dava pronto para entender: que figurava lá uma palavra não de todo estranha:...... adventures ............. das outras porém não podia saber, melhor, talvez, não saberia dizer: as letras, nelas, não se emparelhavam como em português, quer dizer, como na Lucira lhe tinha instruído a reconhecer ditongos uma das meninas de lá, nos vãos daquela sua primeira casa ........ mas reteve-lhes a bizarra sequência na memória privilegiada que era

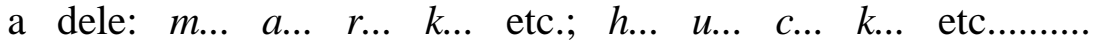
(CARVALHO, 2009, p. 74)

$\mathrm{Na}$ sequência o narrador comentará o apreço de Trindade por cinema. $\mathrm{O}$ cinema, os engenheiros e doutores que conheceu no hotel e com os quais trabalhara e as línguas estrangeiras que ouvia num posto de rádio amador foram os elementos que lhe permitiram "entender que tanto para fora como para dentro de cada pessoa tem sempre mais tanto mundo que às vezes nem dá para querer saber. $"$ (CARVALHO, 2009, p. 77) Ao voltar de sessão do cinema Eurico, Trindade aparecerá não com o "habitual barrete de cozinheiro", mas com "um esfarrapado chapéu de palha em tudo semelhante ao do rapazinho branco que figurava na gravura do livro". (CARVALHO, 2009, p. 78) Ele tinha não apenas arranjado o chapéu como já tinha confirmado a convicção de já ter se deparado com aquelas letras. Por um golpe de sorte a papelaria Regina possuía uma edição em português. O narrador nos conta que ambos, o cozinheiro negro e o engenheiro branco, saíram juntos e lado a lado, em busca dos “papeis” ou da publicação já transformada em objeto de curiosidade e desejo. 
(...) e o Trindade pôde encetar nessa mesma noite, recolhido ao seu canto num acrescento da despensa do hotel e à luz de uma lamparina de óleo de cação, a leitura do primeiro e único livro inteira e exclusivamente seu, porque comprado de propósito para ele próprio ler, em toda a sua vida

(CARVALHO, 2009, p.78)

Na sequência nos dirá ardilosamente que “. poderia ter sido a Cabana do Pai Tomás mas foi o Huckleberry Finn, e aí foi uma sorte para ele, então, e é uma sorte para nós, agora ........" (CARVALHO, 2009, p.79) O narrador nos informa, ao travar a sua conversa com seu sempre interlocutor Paulino, de que as duas obras estão relacionadas à escravatura americana. E que são livros que exprimem visões bem distintas. Se o protagonista de Cabana do Pai Tomás (1852) é um escravo sofredor que pode ser visto como subserviente, em As Aventuras de Huckleberry Finn (1885), temos Jim, um escravo em fuga que unido a Finn, um menino branco a fugir da violência paterna, vivendo aventuras pelo Mississipi e tornando-se assim um possível símbolo da insubmissão e da liberdade. Vejamos um trecho na tradução de Rosaura Eichenberg:

Você não sabe nada de mim se não leu um livro com o nome As aventuras de Tom Sawyer, mas pouco importa. Esse livro foi feito pelo senhor Mark Twain, e ele falou a verdade, no mais das vezes. Teve coisas que ele exagerou, mas no mais das vezes ele falou a verdade. Isso não é nada. Nunca vi ninguém que não mentisse uma vez ou outra, a não ser a tia Polly, ou a viúva, ou talvez Mary. A tia Polly - a tia Polly de Tom - e Mary e a Viúva Douglas todas aparecem nesse livro, que é em geral um livro verdadeiro, com alguns exageros, como eu disse antes. (TWAIN, 2011, p.11)

Basta iniciarmos a leitura dessa obra seminal de Twain para nos darmos conta dos vários diálogos estabelecidos por Ruy Duarte de Carvalho. Em primeiro lugar, há que se mencionar a quebra da ilusão narrativa com o narrador personagem se referindo a um livro anterior e ao próprio autor, Mark Twain, inclusive dizendo que ele, na maior parte das vezes, diz a verdade. Ou seja, o narrador personagem aponta para o artefato da 
ficção. Estratégia recorrente na obra de Carvalho, extremamente atravessada pela metalinguagem. Outro elemento seria a possibilidade de espelhamento entre personagem e autor. Assim como Finn e Jim, também Mark Twain cruzara o Mississipi como condutor de barco a vapor, além de ter tido uma vivência repleta de percalços, o que inclui trabalhos como impressor, mineiro, e falência após ter conquistado dinheiro com seus escritos. Os livros de Carvalho nos colocam igualmente diante desta possibilidade de espelhamento entre vida e obra.

Por conta desses elementos não será à toa que o narrador em A terceira metade dirá ser uma sorte que o primeiro livro de Trindade tenha sido as aventuras escritas por Mark Twain. Evidentemente, as afinidades se dão com essa obra e com os percursos e percalços de seu autor. No entanto, não poderemos nos esquecer daquela obra que poderia ter sido, Cabana do Pai Tomás, de Harriet Beecher Stowe, publicado entre 1851 e 1852.

O "poderia ter sido" nos leva a uma oposição interessante para entendermos a personagem. Poderia ter sido por ser um livro muito popular, inclusive no Brasil tivemos no final da década de sessenta uma adaptação para a teledramaturgia causadora de certo desconforto por possuir Sérgio Cardoso, um ator branco, no papel de Pai Tomás. E poderia ter sido também porque o paradigma proposto pela obra não é alheio a postura de Trindade. Trindade não está nem para os símbolos da insubordinação, embora seja alimentado por eles; nem para os símbolos da acomodação, embora esta possa lhe servir de estratégia.

Antes de prosseguirmos, vale tomar nota de crítica publicada em A cultura do romance, extensa coletânea de ensaios organizada por Franco Moretti. Alessandro Portelli avalia que o sentimentalismo com que as personagens do romance de Harriet Beecher Stowe são compostas reflete as convicções morais da autora. Ao compor uma 
personagem que não deve ser lida realisticamente, na medida em que suas virtudes se tornam sobre-humanas, o objetivo da autora seria o de, sinceramente, despertar a compaixão. Para Portelli a ideia de servilidade de Pai Tomás não emergiria inteiramente das páginas de Stowe, mas teria sido produzida muito mais a partir das adaptações da obra e por algum enviesamento crítico perpetrado no contexto da luta por direitos civis nos anos sessenta. Para o ensaísta é plenamente sustentável concebermos a personagem como representação da resistência interna.

(...) Afinal, o que permanece é a figura imponente, de modos suaves e princípios incorruptíveis, desse "pai" Tomás, que prefere morrer a trair seus companheiros e a si mesmo. Não será um modelo para revolucionários e libertadores, mas merece todo o nosso respeito. (PORTELLI, 2009, p. 514)

O modo pelo qual Trindade lida com os valores estrangeiros nos permite entender que a personagem está sempre pronta para absorver o que lhe interessar dos mundos disponíveis ou daquilo que lhe chega.

Num período em que viveu junto a pastores e anterior ao seu trabalho como cozinheiro em um hotel,

(...) Trindade começou a dar conta que a vida talvez não seja senão um somatório, quase sempre sem nexo para quem se interroga, e sem carecer de nexo nenhum para quem não se interroga, de contradições e de arranjos, dualidades, uniões, instrumentos de relação, movimento que atrai princípios opostos, preservação da existência, realização da procriação............... que há famílias e há casas, mães e linhas de sangue, pais e linhas de fogos sagrados, que há vizinhos e outros, e coisas úteis na casa do amigo e coisas úteis na do inimigo (CARVALHO, 2009, p. 58)

Trindade é esta consciência mestiça, plena e pronta para o devir universal, mediterrânica, sempre atenta para "um caminho aberto por entre os embates das refregas dos outros" (CARVALHO, 2009, p. 96) Sendo negro e estando sob a vigência 
do sistema colonial, não recusa o convívio com os brancos e não recusa as aprendizagens ou a formação que essa convivência pode lhe trazer. Ao contrário, ele deseja o convívio com os estrangeiros e alimenta-se dele o mais que pode. Diferentemente de Jim e Finn, Trindade não recusa o universo trazido pelas letras, antes as soletra, as decifra e as recompõe no corpo de sua voz. Sua subversão é profunda.

Ao considerar a possibilidade de haver coisas úteis na casa do inimigo, seu pragmatismo não dispensa a visão ideal de relações pautadas pela troca e não pela usurpação. Será difícil a partir desse enunciado, não ouvir o sopro da voz de Herman Melville, autor do clássico Moby Dick, brevemente evocado em A terceira metade.

(...) O porto é benévolo, nele há segurança, conforto, lareira, alimento, lençóis quentes, amigos, tudo que é caro à nossa mortalidade. Porém, na tempestade, o porto e a terra são os piores inimigos do navio e ele deve fugir de toda hospitalidade. Mesmo que o contato com a quilha seja levíssimo, qualquer toque de terra o faria tremer da proa até a popa. Com todo seu poder, ele enfuna todas as suas velas para sair do porto, e ao fazê-lo luta contra os ventos que de bom grado o levariam para terra e busca novamente o mar fustigante, longe da terra. Corre ao encontro do perigo para encontrar refúgio. Seu único amigo é o seu mais amargo inimigo! (MELVILLE, 2012, p. 145)

Na refrega entre o mar e terra durante a tempestade, uma embarcação necessita encontrar um caminho nesse embate que não lhe pertence. Trindade é como essa embarcação que, às vezes, deve afastar-se dos que seriam os seus partindo em busca de trocas com amigos improváveis.

A imagem que o discurso de Trindade compõe aos leitores, ou seja, a constituição de um caminho entre dualidades, nos leva diretamente a outro grande escritor fundamental para refletirmos sobre a personagem e o livro, Guimarães Rosa.

Antes, porém, temos que nos voltar um pouco para Desmedida, livro de 2006; portanto, publicado após As paisagens propícias e anterior ao A terceira metade. 
Situado no meio da trilogia "Os filhos de Próspero", Desmedida possui uma relação particular com o terceiro livro. Ele é o anúncio do mergulho que Carvalho, provavelmente, já estava fazendo ou se preparando para fazer.

O livro relata a viagem que o autor cumprira pelo rio São Francisco, segundo ele para ver os sertões de Euclydes da Cunha e Guimarães Rosa. Também se trata de um livro repleto de citações e dentre elas cabe lembrar que Carvalho nos instiga, apropriadamente, evocando-nos a memória dos sertões de Teodoro Sampaio.

É questão pessoal minha, mas esta viagem não virá a ter qualquer razão de ser se eu não souber aproveitá-la para passar a ver-me no Brasil onde estou. Um branco assim como eu, que passou a vida toda em Angola a tentar fazer o que podia pela terra e ainda assim atento ao que lhe chegava do Brasil, a ler os seus Freyres, os seus Josués ( de Josué de Castro é que ninguém fala mais...), e a esbarrar em rosas, a tropeçar em Euclides, enleva-se agora com o caso de um engenheiro que, a par do lugar proeminente que ocupa nas arenas do progresso e da modernização, se empenha junto de senhores de engenho para ver se consegue alforriar irmãos seus, escravos e negros. Implicado em questões de cor de pele durante a vida inteira, não consigo deixar de deter-me num fenômeno assim tão imediatamente perturbador e à dimensão da desmedida brasileira. (CARVALHO, 2010, p189)

O excerto acima nos permite ilustrar a relação que o autor possui com as letras brasileiras e com o próprio país. Relações que são anteriores à viagem relatada ou refletida nesse diário de vigem no qual entram crônicas sobre personagens históricas, depoimentos, reflexões pertinentes aos campos da sociologia e da política, caras também ao pensamento social brasileiro, enfim, e tudo isso alinhavado numa prosa ensaística caleidoscópica.

O baiano Teodoro Sampaio, um mulato filho de mãe negra e pai branco, engenheiro de grande talento esteve presente em importantes obras de infraestrutura das últimas décadas do século XIX. Sua viagem de reconhecimento pelo rio São Francisco 
está registrada na obra $O$ rio de $S$. Francisco e a chapada Diamantina: trechos de um diário de viagem (1879-80), publicado em 1905.

Além de Teodoro Sampaio, desfilam por Desmedida Cendrars, Richard Burton, Capistrano de Abreu, entre outros companheiros convidados para a viagem de Ruy Duarte de Carvalho e, certamente, as viagens de Guimarães Rosa e suas personagens figuram como marca indelével neste cruzar o São Francisco por distantes tempos e com diferentes dicções.

A admiração de Carvalho por Rosa é profunda e se torna evidente em seus últimos livros. Em Desmedida, o autor percorre os espaços aos quais Rosa se dedicara e dos quais aprendera a extrair os materiais utilizados nas construções e nas depurações de seu verbo e de sua voz. Em A terceira metade, Carvalho nos coloca diante de uma personagem cujo fascínio exercido sobre os leitores os faz dialogar com a obra roseana. O próprio título já nos serve como índice para compreensão dos diálogos propostos pelo angolano. Desmedida aparece dividida em Primeira metade e Segunda metade, sendo que no início desta Segunda metade, o autor indica que teria sido escrita em São Paulo, antes de uma interrupção da viagem pelo São Francisco para uma ida a Luanda, sua casa. Verdade, artifício textual ou mistura de ambos, o fato é que na Segunda metade entram reflexões em torno de Luanda, segundo o autor, lá escritas.

Talvez a questão seja sempre, afinal, a de tentar não perder de vista para quem se quer falar, de viva voz ou por escrito, à luz no entanto e ainda assim de uma sem dúvida muito chocante evidencia: quem é analfabeto nada lê, de fato, e também de fato pouco ou nada leem aqueles que beneficiaram de aprendizagens modernas mas evitam, recusam mesmo, porque antes do mais lhes intimida, toda a escrita que não lhes proponha uma sopa de letras liquidificada pelas tecnologias da midiatização, ou propostas ditas literárias devidas a talentos jornalísticos assim-assim que para se imporem chegam até a vigiar-se de muito perto, não venham a incorrer na desvantagem de querer voar eventualmente mais alto, o que aliás acabaria, 
quem sabe, por revelar, também, a efetiva tibieza dos seus reais talentos. (CARVALHO, 2010, p. 281)

Lemos nesse trecho, uma das ideias fundamentais do autor. A relação entre escritas e oralidades, sujeitos letrados e iletrados, e a certeza de que o mundo é constituído por saberes de variadas feições não condizentes com os que se tornaram os mais recorrentes no interior dos estados-nações modernos. Vale lembrar que, se os saberes são múltiplos, as formas de analfabetismo também são. O que significa dizer que os letrados também permanecerão analfabetos em saberes que não dependem da letra para serem acessados.

Essa reflexão estará também representada nas páginas de A terceira metade. Ela não se inicia em Desmedida e pode ser compreendida como uma presença constante no pensamento do autor. Desse modo, o título A terceira metade, que é o terceiro romance de sua trilogia, funciona também como um indicador que nos remete ao livro anterior, Desmedida, em que o autor tornou evidente o seu diálogo com a obra de Guimarães Rosa.

As viagens de Jonas Trindade são viagens para o interior do território e para o interior de si. Suas mudanças de lugar representam acréscimos a uma identidade marcada pelas contingências de um mundo misturado. Não são rupturas, são continuidades ou fases de um mesmo percurso.

Toda a obra de Guimarães Rosa e toda a poética por ela erigida poderia ser evocada para a compreensão de Trindade e do romance, no entanto, há um texto cuja referência é explícita: "O recado do morro".

A estória pertencia originalmente ao Corpo de baile de 1956. Desde de 1964, com a separação em três livros, Manuelzão e Miguilim, No Urubuquaquá no Pinhém e Noites do sertão, ela passa a ser publicada no segundo. 
"O recado do morro" nos traz uma estória de sabor bem roseano com amores e traição. Pedro Orósio, personagem principal, conduz uma viagem exploratória comandada pelo naturalista Seo Alquiste (também chamado Olquiste), Frei Sinfrão, e Seu Jujuca, um fazendeiro. Na leitura de José Miguel Wisnik (1998), podemos identificar o naturalista, o Frei e o fazendeiro como três alegorias dos braços da colonização. Na viagem que realizam encontrarão uma série de loucos do sertão e por meio deles se formula o recado do morro, uma espécie de aviso de que Pedro Orósio será traído.

São muitas as interpretações que podem ser formuladas para a estória e toda a rede formada pela composição dos tipos que por ela circulam. Para os limites do nosso trabalho nos centraremos em Seo Alquiste, representante das letras, das ciências, do universo de saberes e práticas da cultura letrada. Vejamos o trecho em que o estrangeiro do texto de Rosa é evocado pela memória do autor de A terceira metade.

faz tanto tempo já que a gente se conhece e se detém nesta geografia, e ela muda de cada vez conforme a situação, as circunstancias, a companhia, a conversa, o tempo até que faz e o que você sonhou na noite anterior........ como não lembrar-me ali agora, integrado numa tropa de burros em fila indiana, da estória de Guimarães Rosa em que um cientista alemão, o seu Alciste, explora as imediações do Morro da Graça, em Minas Gerais, no Brasil, por onde andei também a cheirar não faz ainda dois anos sequer? (CARVALHO, 2009, p. 374)

Com a grafia de Alciste, Carvalho evoca a personagem de Guimarães Rosa, pois como na estória roseana, há nesse ponto da narrativa de A terceira metade, um doutor e um sujeito não escolarizado e identificado como portador do saber oral. Vejamos como a evocação surge no livro anterior, Desmedida.

Vem pois o dr. João com esses todos e mais o primo, dono do gado, em comitiva por aí abaixo - todos debaixo do 
comando do supremo capataz Manuelzão de rosto longo, tipo asceta, austero e fechado, e nem de muitas palavras - com um caderno suspenso ao pescoço para anotar aí, em letra miúda, o que vê e ouve, tudo do sertão, pedras e calhaus, rama e folhinha, fio de capim, berros e pios, maneiras e modos, falas e silêncios, bois e vaqueiros, pés-duros e chapéus-de-couro. O gosto pelo pormenor, a paixão pelo detalhe. $O$ Sr. Guimarães Rosa despeja nomes de tudo - plantas, bichos, passarinhos, lugares, modas enrolados em locuções e construções de humilhar os citadinos. Irra, que é talento demais, proclama Antonio Candido assim que Sagarana aparece... Talento e notas, muito serviço e obstinação. Qual o alemão seu Alquiste do Recado do morro, de caderno sempre também à mão e codaque a tiracolo, em explorações por tais lugares, os mesmos, sempre sob vigiação. De tudo a tirar o traço, e figura leal, essas minúcias, e perguntando, sempre. Seu Alquiste especulava perguntas e punha em tudo o que lhe diziam uma atenção aguda, quase angustiada. (CARVALHO, 2010, p. 112)

Em Desmedida o nome da personagem está registrado de acordo com uma das variantes do texto original, registramos apenas por curiosidade. Vale registrar também que em A terceira metade o Morro da Garça da estória do Rosa, aparece como Morro da Graça. Pode ser apenas uma distração do autor ou de edição, de qualquer forma a variação é sugestiva, tanto para a estória quanto para o romance. Outro registro que impera fazer é o espelhamento entre as ações de Guimarães Rosa e as de sua personagem, Seu Alquiste ou Olquiste. Ambos são viajantes e inquiridores de um mundo natural e cultural que lhes é estrangeiro. Embora o autor possua nacionalidade brasileira, os espaços e paisagens percorridos são para ele objetos de uma amorosa pesquisa. E ambos de tudo tomam nota em seus insubstituíveis cadernos de campo. Mesmo a presença de uma câmera fotográfica não altera a necessidade da escrita, pois é ela, ou seja, o discurso verbal, que garante a existência das coisas. São como crianças aprendendo a caminhar. Vejamos o trecho do conto em que o explorador alemão é apresentado. 
Seguindo-o, a cavalo, três patrões, entrajados e de limpo aspecto, gente de pessoa. Um, de fora, a quem tratavam por seo Alquiste ou Olquiste - espigo, alemão-rana, com raro cabelim barba-de-milho e cara de barata descascada. O sol faiscava-lhe nos aros dos óculos, mas, tirados os óculos, de grossas lentes, seus olhos se amaciavam num aguado azul, inocente e terno, que até por si semblava rir, aos poucos se acostumando com a forte luz daqueles altos. Calçava botas cor de chocolate, de um novo feitio; por cima da roupa clara, vestia guarda-pó de linho, para verde; traspassava a tiracol as correias da codaque e do binóculo; na cabeça um chapéu de palha de abas demais de largas, arranjado ali na roça. Enxacoco e desguisado nos usos, a tudo quanto enxergava dava um mesmo engraçado valor: fosse uma pedrinha, uma pedra, um cipó, uma terra de barranco, um passarinho atôa, uma moita de carrapicho, um ninhol de vêspos. (ROSA, 2001, p. 30)

Devemos notar a atenção que o autor confere aos olhos. Amparado por óculos de lentes grossas para tudo ver melhor e, certamente, porque tanto esses olhos já apreenderam; eles são macios no seu azul aguado, inocente e terno. A descrição dos olhos combinada à face e cabelos compõe um homem frágil; no entanto, seus olhos já se habituavam a luz forte do lugar. Atrapalhado com a língua, exótico e inconveniente a tudo procura destinar a mesma atenção com seus olhos para "vigiação" para usar o termo do texto de Carvalho. Ou os "olhos do império" na acepção de Mary Pratt, já comentada anteriormente. A contradição se instala por completo. Os olhos são e não são inocentes. São olhos encantados com os novos espaços e ao mesmo tempo o que eles observam e registram pode escapar ao domínio do observador quando transformado em peças de informação acadêmica e científica, ou ainda de outra ordem.

Seu Alquiste simboliza o olhar estrangeiro sobre o novo mundo, como na análise de Wisniki. E simboliza o encontro da cultura letrada com o universo popular e oral. No ponto do romance em que Carvalho evoca Seu Alquiste e o Morro da Garça ou da Graça, temos a imagem do autor e de Trindade montados em burros trotando e ruminando. 
Homero e sua Odisseia centralizam e promovem o eixo da conversa. Encanta Trindade a apresentação de um mundo em que "a humanidade dos brancos se confunde, ou se mistura, com a animalidade e com a divindade." (CARVALHO, 2009, p. 376) Para ele, há um diálogo evidente entre esse universo de misturas e o que podia reconhecer a partir dos saberes apreendidos em suas viagens. Trindade encontra vasos comunicantes entre esses universos, na medida em que é possível vislumbrar a partir de ambos uma ideia de totalidade, sem separação entre homem, natureza e divindade. No entanto a lógica ocidental caminhou para uma fragmentação dos saberes acompanhada por um desencantamento do mundo que passou a dominar e a suprimir lógicas participantes de outras ordens.

No parte que leva o título de "Uma grande volta paradigmática" lemos a seguinte indicação:

(...... até aqui de burro os dois, de frente um para o outro...... a partir de agora, e devido à natureza do terreno, entre brechas na pedra a subir, ambos de burro à mesma, mas o autor atrás do Trindade, este escarranchado de costas para a cabeça do animal e para os rumos do ir......) (CARVALHO, 2009, p.397)

Trindade nos colocará a par de uma reflexão que, segundo ele, também seria a de Severo seu sobrinho, a quem o leitor já conhecera em As paisagens propícias. Na visão desenvolvida compreenderemos que "volta paradigmática" não significa admitir que os "pretos" possam avaliar o mundo e aproveitar-se disso de acordo com os seus interesses, "volta paradigmática" seria todos admitirem que não brancos também possuem coisas a ensinar, também podem promover contribuições que sejam de interesse global. (CARVALHO, 2009, p.398)

Interessante notar a indicação entre parêntesis lida acima. A partir deste ponto Trindade caminha à frente, ou seja, o autor, símbolo da cultura letrada e do saber 
dominante, segue depois, somente à escuta das ruminações daquele mestiço de olhar retrospectivo. Entendemos que essa disposição cênica significa que "os rumos do ir" decorrem desta visada que enseja abarcar as partidas e as trajetórias percorridas. Assim como Pedro Orósio conduz o naturalista, Trindade conduz o antropólogo. Talvez já seja a tal "volta paradigmática".

Em seu último romance, Ruy Duarte de Carvalho nos trouxe a terceira possibilidade de composição de personagens significativas para o contexto social de diferentes sociedades quando miramos o contexto global. Tendo se dedicado a uma personagem branca em Os papéis do inglês e a uma personagem mulata em As paisagens propícias, faltava-lhe a personagem negra para completar o quadro das possibilidades ou imposições identitárias traçadas a partir da percepção das diferenças. São os filhos de Próspero na definição metafórica utilizada pelo autor para nomear sua trilogia.

esta maneira de contar para o Paulino a partir da trama das nossas próprias andanças, minhas e dele, e do relato delas em livros anteriores, seria desta vez para o autor a via de arriscar o esboço de um terceiro olhar porque desta vez, enfim, na trama dos enredos com que me atrevo a querer lidar sem ser ficcionista, não se trataria do discurso de um branco ou de um mulato que se atribuíssem uma palpitação de africanos, como já tinha ensaiado antes ........ desta vez seria o de um absoluto africano inteiramente 'negro' ...... mas também não seria o de um negro africano ocidentalizado que para saber alguma coisa sobre os africanos tem de recorrer ao que o discurso dos brancos produziu a tal respeito, nem o daquele, ainda, que sendo "africano e "negro" embora nado, criado, e produzido não importa onde no mundo, invoca a seu favor, para legitimar e impor um discurso de "africano" (...) o Trindade é negro, sim, mas é mucuísso, não é banto de origem ........ e no contexto em que sempre viveu nunca deixou de ser-lhe lembrado, tanto por brancos como por negros, que a sua 'raça' é a de um twa, de um vátua, de um 'primitivo pré-banto', domesticado tanto pela incidência banta como pela incidência ocidental ..... um absoluto imprevisto olhar, portanto e de qualquer maneira ............... e, para o autor, talvez, uma terceira metade da mesmíssima coisa que tinha andado a tentar querer 
dizer antes, dando notícia de outros olhares...... (...) (CARVALHO, 2009, p. 22-23)

Nos dois primeiros livros da trilogia temos como protagonistas homens ilustrados nas letras, criados fora da África, mas que possuem uma ligação com o continente. Archibald Perkings, o antropólogo de Os papeis do inglês, volta ao continente como uma forma de fuga das questões profissionais e pessoais que o envolvera, mas também como retorno à memória do lugar onde crescera. Severo, o agrimensor de As paisagens propícias, possui pai branco e mãe negra africana. Trindade seria a terceira ponta, a personagem negra nascida e crescida em paisagens africanas, mais precisamente, entre paisagens angolanas e namibianas. No entanto, o autor continua nos provocando com sutis ironias que buscam representar a complexidade da própria vida num mundo misturado. Já no início quando nos anuncia o "absoluto africano inteiramente "negro" entendemos pelo uso das aspas que não será bem assim. E ele não demora muito para nos confirmar, pois na sequencia a personagem nos é apresentada como um mucuísso que teve que aprender a viver entre instâncias brancas e bantas. Ou seja, a expectativa do autêntico, do original ou do puro não pode ser cumprida. O "domesticado" utilizado pelo autor também possui um tom irônico, já que na trajetória de formação da consciência da personagem nos depararemos com momentos em que a sua deliberação sobre si é o que a move. Como uma hiena, Trindade aprende a retirar o máximo de todos os nutrientes disponíveis.

Quando Carvalho se propõe a retratar um negro africano, mas que não é banto, também aí reside o interesse sempre reafirmado pelo autor pelos sujeitos de fronteira, os deslocados ou não encaixados nas identidades majoritárias ou mais bem representadas. Angola é constituída por etnias de origem banta em sua maioria e vemos que Carvalho se dedica justamente a uma personagem que embora negra e africana, não é banta de origem e cresceu entre incidências bantas e ocidentais. Vemos desenhar-se o interesse 
do antropólogo pelas identidades em processo, ou em mobilidade, ou em estado de fronteira.

Nas ponderações do autor, em texto intitulado 'Sobre a 'composição étnica' de Angola" e publicado no volume A câmara, a escrita e a coisa dita..., livro de 2008 que reúne diversos textos de intervenção do autor:

$\mathrm{Na}$ Angola actual subsistem as línguas, as memórias, as tradições, certas práticas materiais ou rituais, expressões, cognições e afirmações de "pertença", que remetem a maioria de cada um dos sujeitos angolanos às imputações étnicas que as cartografias tradicionais consignam. Mas se por um lado não cabem aí todos os sujeitos angolanos, pelo outro também não cabem num tal quadro alguns dos termos dominantes da actual configuração social angolana. Há Angolanos mestiços e brancos, por exemplo, que escapam a uma perspectiva "étnica". Há também "grupos sociologicamente diferenciáveis e constituídos a partir de "stocks" indígenas, como os Kimbar que hoje integram as elites do Namibe, que escapam a uma caracterização estritamente "étnica", embora revelem uma singularidade cultural, histórica e até linguística. (...) (CARVALHO, 2008, p. 67)

O trecho acima confirma o interesse do autor pela complexidade das tramas identitárias pertencentes ao território angolano. Ainda que, em termos gerais, muitos angolanos possam identificar-se com as categorias identitárias definidas pelas cartas étnicas, mesmo pesando sobre essas denominações marcas do processo colonial, há também muitos sujeitos que não podem ser inseridos nas mesmas categorias de análise. E Ruy Duarte de Carvalho demonstrou enorme interesse por essa complexidade. Podemos dizer que o interesse por situações de fronteira marcou suas trajetórias enquanto antropólogo e artista. Conforme nos propõe Rita Chaves:

(...) Poeta e ficcionista, Ruy Duarte, além da palavra, percorre o universo da pura imagem e do movimento, traduzindo assim um modo de estar no mundo que o desenho e o cinema ajudam a completar. Sobre a vida nem sempre camarada, o poeta-cineasta vai lançando a palavra e a câmera e extrai do real a luz e a sombra poéticas que o momento, às vezes, nem sabe que fermenta. Sob o signo da letra e/ou com a cumplicidade para além do verbo, sua obra se tem definido pela pluralidade e não abre mão dos materiais acumulados pela 
experiência da vida diária, transformando seu chão em matriz de sentidos. (CHAVES, 2007, p. 109-110)

As belas palavras de Chaves nos indicam que a própria produção de Carvalho se situa na fronteira de diferentes artes e diferentes saberes. E podemos identificar em sua poesia, em seu cinema, em sua antropologia, em sua ficção e em seus desenhos a sua preocupação com o outro, com a constituição das identidades em Angola.

Desde o primeiro romance acompanhamos o desenvolver da complexidade humana e social a que os percursos e identidades das personagens nos remetem. Archibald Perkings, um branco nascido em África, formado em contexto europeu vem a se tornar por conta de suas decepções um sujeito desgarrado, um branco destituído de suas ligações anteriores. O "branco da Namíbia" ou o mulato Severo possui um percurso semelhante, também volta a terra onde estão suas raízes, onde se encontra com a história de sua mãe negra africana. Trindade representa, nas palavras do autor "uma terceira metade da mesmíssima coisa". O autor cria representações de um mundo misturado.

Podemos sugerir a partir do conhecido ensaio de Antonio Candido "O homem dos avessos", publicado em Tese e antítese (1964) que em Ruy Duarte também contemplamos uma representação literária estruturada em ambiguidades de várias ordens. Candido considera que podemos observar, em Grande sertão: veredas, ambiguidades de várias ordens: ambiguidade da geografia, pois há um deslizamento para o espaço lendário, ambiguidade dos tipos sociais, pois estão entre a Cavalaria e o banditismo, ambiguidade afetiva, representada pela oscilação entre amor sagrado e amor profano, mas também simbolizada pela ambiguidade da figura de Diadorim, e finalmente, a questão entre o bem e o mal. Segundo Candido, "estes diversos planos de ambiguidade compõem um deslizamento entre os pólos, uma fusão de contrários, uma 
dialética extremamente viva”. (CANDIDO, 1964, p. 135) E a linguagem de Guimarães Rosa materializa pelas criações e misturas em todos os níveis linguísticos, do fonéticofonológico ao discursivo, a complexidade das matérias sociais e humanas sobre as quais se debruçou.

Em Ruy Duarte, de um modo geral, misturam-se o oral no escrito, personagens históricas com personagens reais, saberes europeus e saberes africanos, brancos e negros. Quando consideramos A terceira metade e seu protagonista, Trindade, imerso num universo em vias de "ocidentalização", para usar uma expressão de Ruy Duarte, e investindo numa narrativa em busca de si num mundo misturado, podemos ir ao encontro da visão crítica de Davi Arrigucci em "O mundo misturado: romance e experiência em Guimarães Rosa".

Esse belo ensaio de interpretação do romance Grande sertão: veredas propõe pontos interessantes para refletirmos acerca de Trindade. Riobaldo ao recompor os sentidos de suas experiências via narrativa descobre a tristeza e a alegria, o medo e a coragem, o real e a máscara, o masculino e o feminino, o bem e o mal, e muito mais e tudo misturado. (ARRIGUCCI, 1994, p. 26) Sua compreensão sobre sua existência e acerca da complexidade do mundo está relacionada à capacidade de narrar. Arrigucci considera que a personagem ao questionar o vivido expõe à luz da razão o universo composto por representações arcaicas no qual esteve mergulhado.

Tendo em vista a relação visceral que há entre Ruy Duarte e a obra de Guimarães Rosa, podemos supor que há pontos de interesse nas análises críticas em torno da obra do escritor brasileiro. Com Trindade também temos uma personagem fazendo seu percurso por entre instâncias contrárias, o oral e o escrito, o arcaico e o moderno, o negro e o branco, a insubordinação e a acomodação. E, assim como para 
Riobaldo, a consciência que surge é a de que talvez a compreensão do todo depende da compreensão da interpenetração dos contrários. 


\section{Capítulo 3}

\section{A permanência da poesia}

Os livros de Ruy Duarte de Carvalho nos inquietam em relação aos gêneros empregados e esta é uma discussão sempre muito presente em torno de sua obra. Tomemos como ponto de partida considerações de Sandro Ornellas a respeito de Vou lá visitar pastores:

No desconcertante Vou lá visitar pastores, de 1999, estratégias etnográficas e estratégias ficcionais dão as mãos para a montagem da cena da enunciação, cujo principal argumento é uma introdução ao conhecimento do povo de pastores nômades Kuvale do sul de Angola, deserto do Namibe. Esse argumento, no entanto, é incessantemente recortado, atravessado, interrompido, problematizado e questionado ao longo da narrativa, ela mesma fragmentada em pequenos extratos que se assemelham mais a breves textos literário-ensaísticos, naquilo que esse gênero tem de mais característico: a argumentação flutuante. (ORNELLAS, 2009, p. 195)

A argumentação flutua na medida em que o pensamento que se desnuda e se mostra em processo busca a forma de sua expressão. O que nos faz pensar nos enormes desafios para se encontrar as questões adequadas num contexto sociocultural estruturado por múltiplas tensões. Uma proposição recorrente na obra de Ruy Duarte de Carvalho é justamente compreender o modo pelo qual o Estado constituído se relaciona ou poderá se relacionar com as identidades coletivas parcelares existentes na comunidade angolana. Podemos interpretar a variação dos gêneros ou essa argumentação flutuante como indicadora de um pensamento-ação em liberdade e em busca das formas do entendimento adequado. 
Ruy Duarte de Carvalho iniciou sua obra pela poesia. A leitura do conjunto de seus títulos nos revela que ele jamais a abandonou. Ela permaneceu como força motriz em sua escrita. Se a versificação se tornou quase ausente ao longo de seu percurso, a poesia se fez plena numa prosa que, caudalosa, soube abrigar saberes múltiplos, variando no exercício dos gêneros conhecidos e sempre em busca da palavra fulgurante.

Estamos considerando que as sendas abertas pelo poeta permaneceram em sua trajetória definindo o seu exercício como escritor. Como confirma Rita Chaves em seu trabalho Narrativa e espaço: Angola, Moçambique e alguns ecos do império (2012), desde sua estreia como poeta, nos anos 70, Carvalho se volta para os espaços do sul e para os povos do sul como fonte de sua poética. Nisso, contraria um dos focos de produção da literatura angolana, ou seja, a cidade de Luanda. Tania Macedo, em Luanda, cidade e literatura (2008), demonstra a importância da capital como símbolo recorrente em diversos autores e em diversas obras. Macedo considera que o processo de reafricanização da cidade nas produções literárias que a tem como espaço recriado literariamente, corresponde ao projeto político de construção da nacionalidade. (MACEDO, 2008, p. 16)

Em seu primeiro poema, intitulado "O sul", e publicado em Chão de oferta (1972) já vemos o autor dedicando-se ao sul, algo que ecoará para outros poemas do livro. Segundo Chaves (2012), devemos reter também que o distanciamento de Carvalho de seus contemporâneos nesses inícios se deu tanto na eleição do espaço, quanto nas formas da linguagem. Já nos anos 70, sua poética distanciava-se da retórica dos discursos nacionalistas.

Vejamos um dos poemas do autor que deflagra a oferta que faz ao leitor das imagens do chão que escolhera para fundar sua poética: 
Venho de um sul

Eu vim ao leste

dimensionar a noite

em gestos largos

que inventei no sul

pastoreando mulolas e anharas

claras

como coxas recordadas em maio.

Venho de um sul

medido claramente

em transparência de água fresca de amanhã.

De um tempo circular

liberto de estações.

De uma nação de corpos transumantes

confundidos

na cor da crosta acúlea

de um negro chão elaborado em brasa.

(CARVALHO, 2005, p. 35)

Não temos a intenção de realizar análise de poemas, pois embrenharmo-nos nesta fecunda poesia que pode ser apreciada na antologia Lavra: poesia reunida 19702000, publicada em 2005, exigiria outro tipo de enfoque. Citamos "Venho de um sul", no intuito de exemplificar as diferentes escolhas de Carvalho. No poema verificamos a busca de um espaço onde fundar a criação de imagens literárias e também a opção por uma linguagem não tão afinada com os escritores que farão da Luanda reafricanizada o lugar em que a imaginação efabula de modo recorrente.

Vemos, no poema acima, a inscrição de uma voz poética marcada pela forte impressão que as paisagens e as populações pastoris que transitam por essas paisagens imprimiram na consciência e sensibilidade artística de Ruy Duarte. Como ele próprio declarou a poesia o levou ao cinema que o levou à antropologia, e podemos contemplar em sua poesia a busca e o encontro com os territórios e paisagens que estarão presentes em seu fazer artístico e intelectual. O verso "pastoreando mulolas e anharas" é bastante iluminador. Nele contemplamos a junção entre homem e espaço, ou entre gesto humano, o pastorear, e as paisagens, as terras secas ou alagadiças e as savanas. $\mathrm{O}$ eulírico, ao propor o pastoreio das específicas paisagens que anuncia, comunica-nos a existência de tais paisagens, a existência de populações pastoris que as habitam e nos comunica sobre a integração entre a atividade humana do pastoreio e as condições materiais oferecidas pelo território que a abriga. $\mathrm{O}$ mesmo território emerge no poema 
de modo extremamente afetivo; ele é, ao mesmo tempo, o território de uma atividade econômica e o chão de oferta de paisagens a um olhar embevecido.

Novamente com as palavras de Luís Quintais, podemos propor que:

Talvez todas as paisagens sejam interiores, e quando o Ruy nos descreve uma, ele não está a fazer justiça senão a uma paixão maior que o anima: a procura de uma "auto-colocação", como ele gosta de lhe chamar, onde o que importa está do lado daquele que observa convocando todas as suas utensilhagens verbais para dizer um mundo que é matéria de autometamorfose e encontro: um mapa de si sem o qual não é possível acalentar projectos de descrição em nome alheio. (QUINTAIS, 2006, p. 17)

Inegavelmente, como já assinalaram diversos estudos críticos, o espaço ocupa uma posição privilegiada na obra de Ruy Duarte. O espaço com todas as suas memórias, ocupações e possibilidades em termos de produção de imagens ocupa as páginas e outras expressões artísticas que Carvalho construiu em Angola. Mesmo quando o escritor se dedica às descrições físicas que quase remete o leitor a um texto do campo da geologia ou da geografia, percebemos essas descrições inseminadas pela potência de um olhar afetivo que opera a profunda integração entre observador e o que é observado, transformando-os definitivamente.

Vejamos um trecho de As paisagens propícias que também atingiu a sensibilidade de Luís Quintais no texto já citado:

Sou um devoto de granitos e erosões. E há granitos que remontam às orogêneses: é o caso dos Alpes, parece, na Europa, e das chamadas montanhas na Dâmara, aqui. Tem paisagens por aí que há mais de 500 milhões de anos foram pleniplanícies, niveladas a mais de mil metros acima dessas massas de granito de que agora vemos as cabeças e que, solidificadas assim, estão enterradas vários quilómetros pela crosta terrestre adentro. Esses blocos de granito apenas ficaram expostos à luz do dia sob o efeito de milhões de anos de erosão. E o granito é uma rocha massiva, magmática, cristalina. É duro mas é também muito sujeito àquilo que, em inglês, em português não sei, se chama weathering. É isso que dá os inselbergues. A luz do sol, o vento, a água, as mudanças de temperatura, são agentes que intervêm nesse efeito. Bizarras formas como as que encontramos agora são o resultado de milhões de anos. A bizarria da configuração dessas formas começa quando a rocha está ainda debaixo da terra. Infiltrações, durante épocas muito húmidas, fazem com 
que a água atravesse a crosta e atinja o granito. Ela, a água, move-se, escorre através das fissuras verticais, que são assim lavadas e alargadas. Secciona o granito em blocos quadrados. Entretanto, no decurso dos tais milhões de anos, as moles de granito passam a ver-se porque toda a terra à sua volta vai embora, erosões de superfície. Estão agora expostas a um clima quente e começa a dar-se a "temperature weathering". As matérias mais escuras da pedra absorvem mais calor $\mathrm{e}$ expandem-se mais que as claras. A temperatura desce muito rápido, durante a noite. A estrutura contrai-se e estala. $\mathrm{O}$ granito fende-se. Os blocos reduzem-se, arredondam-se, formam às vezes perfeitas esferas. Esfoliações, entretanto, paralelas à superfície dos blocos, desfolham-se da rocha como peles de cebola. Outras vezes há blocos que parecem ter sido fendidos em duas partes. É a solução e a cristalização dos sais, são as acções biogenéticas, é a pressão de raízes ou a corrosão dos ácidos húmidos. É isso que dá configuração à paisagens de inselbergues e de amontoados caóticos que atravessamos por toda a parte desta Namíbia e por Angola fora, mesmo depois da aridez se interromper, para além, por exemplo, da muralha do Amboim, pelos platôs todos do Kwanza Sul até Malange e para lá, para lá. Falo deste rumo porque foi a falar dos inselbergues da Gabela que SRO me começou a falar de si: tinha nascido lá. (CARVALHO, 2005, p. 47-48)

Como escreveu Quintais, ao citar o belo trecho acima, o "território é representado pela aridez e pela reiteração da aridez" (QUINTAIS, 2006, p. 18) No entanto, o autor encontra e sabe expor a beleza dos terrenos que deslumbram o seu olhar. Há um olhar de poeta que perscruta e ama a paisagem desde a sua gênese. $O$ espaço é apreciado em todas as suas dimensões, mesmo na descrição de suas características físicas Carvalho extrai a força da poesia. A primeira sentença, "Sou um devoto de granitos e de erosões", já encaminha o leitor para a subjetividade do narrador que se empenha numa descrição detalhada que personifica a paisagem. Ela passa a acontecer diante do leitor que pode apreciar tanto o surgimento no texto de uma configuração geológica específica, quanto as adjetivações que o pesquisador imprime sobre tais formas. A subjetividade do poeta-pesquisador conduz as aprendizagens do leitor. No final nos damos conta de que o narrador resolveu falar dos rumos que fala, pois sua personagem, Severo, havia começado a falar de si falando de inselbergues, já que faziam parte de seu local de nascimento. São muitos os campartilhamentos que narrador e personagem farão ao longo da narrativa e a admiração por esse espaço demonstra essa identificação profunda. 
O modo preciso como Carvalho contorna os espaços no desenho de sua escrita nos remete a um dado de sua biografia, ou seja, sua formação como regente agrícola. (CHAVES, 2007, p. 110) A sua relação com as artes visuais também se faz presente nesta textualidade que reconfigura os espaços físicos e se faz igualmente precisa no detalhamento de cenas, como observamos na análise do "Intermezzo" de Os papeis do inglês. O talento do desenhista e do cineasta foi canalizado para a composição de uma prosa sofisticada que permite ao leitor imaginar não apenas lugares e acontecimentos. $\mathrm{O}$ leitor pode também imaginar as iluminações, as cores, as texturas, os movimentos, as extensões, enfim, todos os elementos que compõe a arte do cineasta ou do desenhista concorrem para a produção literária deste intelectual que se traduziu com variados recursos e a partir de diferentes influxos.

Outro aspecto fundamental da poética de Ruy Duarte de Carvalho, já abordado em sua crítica, é a sua relação com a oralidade. No primeiro capítulo buscamos uma abordagem do tema a partir da importância que ele adquiriu no cinema realizado por Carvalho. Constatamos o quanto a necessidade de garantir voz ao outro, ou seja, às populações com as quais entrara em contato enquanto antropólogo, sem distanciamento dos posicionamentos enquanto poeta e cidadão angolano, se tornou uma das questões fundamentais de suas reflexões. Vimos como o tratamento das narrativas orais transpostas para sua obra Nelisita movimentou reflexões e procedimentos que procuravam garantir uma realização estética que dialogasse com o presente vivido pelo grupo que participou do filme.

Podemos considerar que tais reflexões permaneceram e frutificaram também em sua prosa de ficção. A busca pela representação da voz e do outro constitui uma marca forte da poética de Ruy Duarte de Carvalho. Atravessou sua poesia, seu cinema e seus textos em prosa.

Encontramos um bom exemplo da busca pela voz poética na comparação das edições de Como se o mundo não tivesse leste ${ }^{6}$. Na primeira edição de 1977, a segunda estória que possui o título "João Carlos, natural do Chinguar, no Bié" está inteira em prosa. Já a partir da edição de 2003, encontramos trechos em forma de poema que antes estavam alinhados no correr da prosa. Em nota, o autor anuncia:

Suprimi, para esta reedição, muito do que, na versão original destas estórias, me pareceu, agora, entravar o curso do que tinha afinal para contar. Cedi por outro lado à tentação de

\footnotetext{
${ }^{6}$ Para acompanhar uma análise sistematizada do livro: Lidiane Olívio (2013)
} 
dar visibilidade gráfica, na segunda estória, à cadência metrificada que na realidade só se me revelou muito depois de as ter escrito e publicado pela primeira vez. (CARVALHO, 2008, p. 9)

O narrador nos conta a estória de João Carlos, um trabalhador que é contratado para diferentes trabalhos e está sempre em dívidas com armazéns. Possui o desejo de obter bois para lavrar a terra e assim resolver a sua situação.

João Carlos de seu nome,
natural do Chinguar,
pastor de ovelhas agora,
outras coisas noutros tempos:
escalador de peixe grosso
nas salgas da Equimina,
cortador de cana verde
nas baixas da Tentativa,
viveirista de café
nas roças da Boa-estrada,
cozinheiro de alemão
em fazendas de Calulo,
ajudante de tractor
em plantações de sisal.
E as outras coisas cumpridas
Na vida particular:
(CARVALHO, 2008, p. 78)

O conto inicia com João Carlos em um bar e a personagem está desapontada por conta da perda de dois bois. A narrativa girará em torno dessa problemática. $\mathrm{Na}$ apresentação em versos feita pelo narrador é impossível não evocarmos a poética de João Cabral de Melo Neto em Morte e Vida Severina (1966). Assim como Severino, João Carlos é um trabalhador sem destino definido e sempre em busca de trabalho e de condições favoráveis em alguma parte. Em seus périplos só encontram desapontamentos e opressões, mas são homens de uma resistência interna brutal que os faz seguir ${ }^{7}$.

Outra relação que pode ser traçada diz respeito ao uso dos versos em redondilha que, em ambos os autores, estabelece uma relação com a oralidade. Os poemas evocam a voz dos cantadores. O ritmo da letra clama por voz e, no caso de Morte Vida e Severina, a associação imediata é com o universo da cultura oral nordestina com seus

\footnotetext{
${ }^{7}$ Vale registrar a existência de dois trabalhos de literatura comparada que traçam relações entre as poesias de Ruy Duarte de Carvalho e João Cabral de Melo Neto: a dissertação de mestrado de Carla Cristina Bianchi Santos, O espaço nas obras Hábito da terra de Ruy Duarte de Carvalho e A educação pela pedra de João Cabral de Melo Neto (2001); e a tese de doutorado de Marli Paz Souza, Do sul de Angola ao nordeste brasileiro: um itinerário poético (2007).
} 
repentistas e cordelistas, versificadores que atuam entre a poesia e a música, a narração e a canção, o rural e o urbano, a memória dos temas recorrentes e pertencentes à tradição e a permanente atualização temática.

De tudo o que viu na vida, gente boa e gente má, João Carlos retirou duas ou três conclusões: que um homem nem sempre está onde o corpo lhe impõe estar, e o importante na vida é como estar, não aonde.

Na vida de cada um há quatro vidas ao todo: sozinho dentro de si ou perto ou longe dos seus e em estando junto com os outros, da mesma forma, conforme.

Para além de outra que há-de ter onde se vive uma só sem divisões nem viagens. Porém aqui, nestas vidas, o difícil para um homem é entender os sinais e não querer passar além do tempo que lhe respeita.

De há muito que não tem pressa.

Estar na vida é estar assim, hoje aqui, hoje acolá, quem sabe para onde vai?

E quem lhe aponta o caminho?

Toda a vida andou mudando de lugar para lugar, em cada ano viagens, para norte e para sul, terras de chuva e de seca, falas diferentes da sua, costumes outros que o seus. Recorda? Nem tanto assim.

Recorda bem para si, Agora que lhe está longe, é o sítio onde nasceu.

E se passou, na verdade, mais tempo fora que lá, o que recorda é por certo mais obra do que imagina, estando lá sem lá morar, do que os tempos lá vividos, 
gastos, tantos, a pensar

na vida de outros lugares.

As quatro vidas, portanto,

de quem se fez nas ausências.

Então estar agora aqui, que lhe adianta ou atrasa?

Podia estar lá na terra, o sítio que mais recorda, tem lá mulher, tem café, três ou quatro laranjeiras e dois filhos já casados, Mas não foi a vida toda feita de estar só pensando as coisas de lá sabendo que as coisas correm por si, quer pense nelas ou não? Cada um tem o seu tempo. E tem o tempo dos outros Que às vezes encontra o seu. Importante, na verdade, É ter um tempo no mundo. Um homem é onde está, Se a força de viver lhe não fugiu E houver entendimento para o que é vivo. (CARVALHO, 2008, p. 87-89)

Impossível resistir ao gosto de reprodução do longo trecho versificado que reproduzimos. Seja pela força da forma cujo ritmo logo se impõe e nos convida a recitação, ainda que solitária. Seja pelos versos emblemáticos e profundos da personagem. Sua resistência interna e sua capacidade de recompor a vida nos remetem diretamente para o protagonista de A terceira metade, Trindade. Nos versos: "Um homem é onde está,/Se a força do viver lhe não fugiu/E houver entendimento para o que é vivo" devemos atentar para a possibilidade de um discurso indireto livre em que a consciência do narrador se solidariza a de João Carlos. Será também a voz de João Carlos que ouviremos na voz do narrador. Temos escrita e voz solidarizadas em palavras que podem pertencer a ambos. Os deslocamentos de João Carlos e as marcas dolorosas de sua vivência lhe garantem aprendizados que lhe permitem alcançar um discurso sobre si e sobre o mundo: 


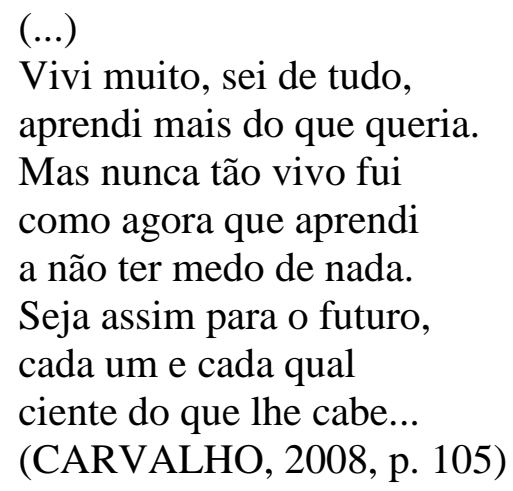

A relação entre João Carlos e Trindade é profunda. São personagens nascidas da mesma matéria, sujeitos que necessitam gerar a si próprios para lembrar o mito de Nelisita. E essas personagens vivem em textos que clamam por voz, textos decididamente marcados pela oralidade. João Carlos nos permite perceber que a busca pelo encontro da voz do narrador ou autor com a voz de suas personagens acompanhou Ruy Duarte ao longo de sua trajetória. Talvez seja o caso de considerarmos a "Nota" explicativa que abre o livro Ondula savana branca um dos marcos inaugurais da busca por uma poética que represente vozes em interação. Como já dissemos no primeiro capítulo, as versões, derivações e reconversões criadas na obra constituem um diálogo aberto com oralidades e escritas abrigadas na consciência de um autor que conjuga erudição e prazer.

Essa busca se transforma em realização plena quando avaliamos seus dois últimos romances: As paisagens propícias com o longo discurso poético de Severo e $A$ terceira metade com Trindade ruminando, intervindo, recompondo memórias, dialogando, continuando falas abertas por Severo, propondo futuros, atribuindo sentidos às suas experiências, ou em resumo, narrando.

A oralidade ou oralidades e suas reconfigurações na escrita tornaram-se uma questão recorrente nas literaturas africanas. Os escritores tomam caminhos diversos nas proposições e estéticas adotadas e não é fácil a produção de sínteses por parte da crítica. 
Conforme nos expõe Ana Mafalda Leite em seu conjunto de ensaios que leva o título de

Oralidades \& escritas nas literaturas africanas (1998).

(...) haverá talvez que se distinguir três tipos de apropriação: o primeiro, o mais frequente, tanto na literatura angolana como na moçambicana, a tendência para seguir uma norma mais ou menos padronizada (como é o caso de Pepetela ou Luís Bernardo Honwana) ou então “oralizar" a língua portuguesa, seguindo registos bem diversificados entre si (por exemplo, o caso de Boaventura Cardoso, Manuel Rui ou de Ungulani Ba Ka Khosa).

O segundo tende a "hibridizá-la" através da recriação sintáctica e lexical e de recombinações linguísticas, provenientes, por vezes, mas nem sempre, de mais do que uma língua (os casos de Luandino Vieira e Mia Couto).

O terceiro, menos frequente, e utilizado apenas por escritores bilíngues, cujo contacto com a ruralidade é mais íntimo e próximo, institui uma relação de diálogo, criando uma espécie de "interseccionismo" linguístico, em que prolongamentos de frases, ou partes de frases, se continuam em diferentes línguas, alternando ou imprimindo ritmos diversificados, assim como fazendo irromper, recuperadas, diferentes cosmovisões. (...) (LEITE,1998, p. 35)

Realmente, não é fácil produzir sínteses diante de matéria tão complexa. Como lemos no texto de Leite, no que ela define como primeiro grupo, convivem projetos e estratégias discursivas bem diversas no que tange à relação com as oralidades ou com os gêneros específicos de uma tradição oral, em geral designados pelo termo oratura. Talvez, por ora, o mais adequado seja investigarmos as particularidades de cada autor no tratamento da matéria social que possuem em seus contextos e a partir dos quais projetam suas obras. Em relação a estas questões que remetem à definição de projetos estéticos no tratamento da matéria básica do escritor, ou seja, a língua nos seus diferentes níveis de constituição e análise, nada melhor do que a palavra crítica do escritor:

O talento que permitia a João Guimarães Rosa e a José Luandino Vieira escreverem daquela maneira pertence, quanto a mim, àquele tipo de talentos que nos leva a dizer, quando vemos 
por exemplo Gilberto Gil ou Ronaldinho Gaúcho a dançarem num palco ou num estádio, que quem é bom já nasce ensinado. Não era portanto, jamais o seria, uma coisa para mim........ isso, como terá dito Jorge Amado precisamente a respeito de GR, "é outra coisa"................ O Brasil deu GR, Angola deu JLV, Moçambique o Mia Couto e é pena que em Cabo Verde António Aurélio Gançalves não tenha sido assistido pelo mesmo génio da língua..... teríamos então talvez um caso mais, e muito sério, talvez o mais sério mesmo, na chamada ficção lusófona, um caso daqueles, talvez, em que, como já dizia Kant há mais de duzentos anos, à profundidade das vistas se alia a graça de uma exposição luminosa........ foi isso também precisamente, quanto a mim, que GR conseguiu e, ao conquistá-lo, produziu uma dessas escritas que transitam da língua para a linguagem sem reduzir em nada o alcance da língua, aumentado-o mas é, e assim adregam conferir-lhe uma pertinência tão adequada a um espaço e a um tempo que o que escrevem se transmuda em voz, autogerada e colectiva voz. (...) (CARVALHO, 2008b, p. 14-15)

O autor possuía o entendimento de que seu caminho não se faria pelas trilhas abertas por Guimarães Rosa e rearticuladas em outras dimensões nas obras de Luandino Vieira e Mia Couto. Ruy Duarte avalia que os "contorcionismos sintácticos" e as “pirotecnias lexicogénicas", ainda que possam constituir um discurso fulgurante, não definem o fazer literário. Comentará o autor que "uma literatura manifestamente diferenciada" não precisa se valer desses recursos e, além disso, há muito mais na obra de Guimarães Rosa.

(...) se GR é de facto um grande escritor não é seguramente só por isso, é porque no que escreve entra aquilo de que se fazem as grandes literaturas, que é a adequação da palavra à condição da experiência, das percepções e da consciência do sujeito humano em situação interactiva. (CARVALHO, 2008a, p. 15)

Tendo em vista apontamentos que já realizamos e colocando a obra de Ruy Duarte em perspectiva, podemos considerar que sua procura e conquista foi a da palavra pulsante no ritmo dos narradores primordiais. Em Ruy Duarte de Carvalho a letra busca a voz e assim caminhamos no sentido das compreensões produzidas por Laura Padilha no belo Entre voz e letra: o lugar da ancestralidade na ficção angolana do século XX 
(1995). Desse trabalho repetimos com prazer a ideia de que "o griot e o escritor se 'acamaradam' e nasce assim o texto ficcional angolano.” (PADILHA, 1995, p. 195) Nesse aspecto, Ruy Duarte faz parte daquela plêiade tratada pela professora em seu trabalho, da qual destacamos Luandino Vieira. Ambos são mestres na representação de um mundo misturado em vários e distintos aspectos. O escritor encontra-se conectado a conjuntos de escritores anteriores ao seu tempo, particularmente, a partir dessa temática. Considerando com Antonio Candido a literatura como um sistema de comunicação inter-humana em que os homens representam e interpretam suas realidades, consideraremos também a importância da tradição enquanto continuidade literária. Sem esquecer que a conexão não é só por aceitação, ela se dá também por oposição ou negação. (CANDIDO, 1959, p. 17)

A solidariedade profunda que há entre a palavra do autor e a palavra de suas personagens contadoras de estórias se materializa no texto a partir do espelhamento que há entre os percursos e a consciência do narrador e os percursos e as consciências das personagens. Como já dissemos, o autor chega a essa formulação em seus dois últimos romances. No Livro III de As paisagens propícias leremos longos discursos que no plano da narrativa são emails que Severo envia para o autor. Ainda no início podemos ler o seguinte trecho.

$\mathrm{O}$ que me mandou antes, nesse primeiro mail de onde andei a extrair os materiais que arrumei e anotei para trás, ficou, segundo ele, com aquela forma de frases desgarradas porque $o$ que fez foi alinhar o que lhe vinha à cabeça. E porque usou um computador portátil que lhe emprestou o francês do lodge do Opuho. O uso do computador, diz ele, veio sugerir-lhe então uma modalidade, parcial sem dúvida, de resolução para um problema, o do tempo das pausas que sempre o tinha incomodado quando queria escrever. Diz que um dia lhe disseram, ou leu, ou então inventou, adivinhou, que a escrita se terá urdido, desde o princípio e ao longo das eras, a perseguir a fixação mais da ideia do que a da fala....... e que ele, nascido mais ou menos a meio de um século em que a literatura 
universal tanto se esforçou para transportar a lógica e a cadência da fala para a escrita, e homem mais de falas que de escritas, gostaria mas era de escrever em pauta...... como quem anota música..... (CARVALHO, 2005, p. 226-227)

No excerto acima, podemos ler o discurso do narrador e o discurso citado de Severo. Ainda estão discerníveis já que o narrador está acertando o passo. Depois leremos trechos longos nos quais a possibilidade de distinção das vozes não é constante. Em boa parte da narrativa elas estarão sobrepostas. Os pensamentos esboçados e os referenciais utilizados pertencem tanto a Severo quanto ao autor que se projeta no texto. O uso do computador para emails é um símbolo interessante, pois nos remete diretamente para a ideia de conexão em rede via novas tecnologias ao mesmo tempo em que converge para uma escrita cuja natureza do gênero email possui vínculos com a oralidade enquanto fala cotidiana. O desejo de Severo reportado pelo narrador é o de encontrar uma escrita que transmita a cadência da fala e se amplie por ramificações intermináveis.

cada um com a sua gente mas com gente sua entre toda gente.... é isso que em meu entender pode servir a uma ideia de nação...... qualquer coisa dentro daquilo que há-de vir um dia a remediar em África a falácia e a irredutível inevitabilidade etnocida da configuração geopolítica legada pelo tratado de Berlim.... (CARVALHO, 2005, p. 302)

Vejamos outro trecho um pouco mais adiante na sequência de leitura:

foi tudo isso, a Epupa, e sobretudo ter passado tantos anos a atravessar a experiência, a fermentar a consciência e a organizar a vida dentro de uma maneira tão particular do real ordinário, que me levou assim que pude a ir ver o que estava escrito sobre as maneiras com que eu tinha andado a lidar e sobre os hereros e outros implicados nesta tal mancha clânica... e sobre os pastoris de uma maneira geral e as sociedades ditas de economia arcaica, e tudo isso por aí fora que envolvesse o que os distingue todos, uns e outros, no mundo de hoje, em termos de acção, práticas, comportamentos, lógicas, instituições, representações, símbolos....... pensei nisso logo que no Kambêno 
começou a luzir a possibilidade de vir mais cedo ou mais tarde a poder apontar a Opuho......... começava a estar bem nessa altura, e nunca estive tão bem como quando vivi na casa do mais-velho Trindade mas. (CARVALHO, 2005, p. 304)

Nesse trecho, que pertence ao discurso de Severo, vemos a personagem alçada à categoria de narrador do romance. E é a sua voz que vamos acompanhar com esses pontilhados da escrita que tentam recuperar as pausas e os silêncios da fala. As falas são longas e os silêncios constantes. Vemos nisso a representação de um pensamento ou de uma consciência que vai sendo elaborada aos poucos, ela vai se constituindo e se fortalecendo diante do leitor. O pensamento vai e volta, oscila, sendo produzido entre interrupções e retomadas sua cadência busca a harmonia. A narrativa de Severo almeja a música, sua escrita deseja a universalidade de uma partitura. Nesse caso vemos a representação da oralidade enquanto fala se organizando para a produção de um discurso matizado por considerações políticas.

No primeiro trecho tomamos contato com um momento de reflexão em torno da ideia de nação e a constatação de que as fronteiras de África foram traçadas fora dela. No segundo trecho lemos a referência ao contato com povos pastores e também com a personagem Trindade. Há um espelhamento entre Severo e o narrador que nos leva a consideração de que eles compartilham a palavra e a consciência. A consciência de Severo quando faz suas ponderações, quando emite seus juízos, quando evoca experiências de vida e de leituras nos remete diretamente para a consciência do narrador e, por conseguinte, do autor. As considerações do agrimensor Severo são as do antropólogo que narra o romance. Vejamos um trecho de A terceira metade:

(...)............ SRO, com o seu humor hipercínico, achava que nós aqui, nesta beirada do continente e do mundo, temos a configuração de uma possível nação em termos, quer dizer, diversos grupos de pessoas implicados numa dinâmica e numa decisão comuns, porque embora não sendo só "uns", sendo 
vários "outros" uns para os outros e entre si, se reconhecem e se identificam em relação a referências e a interesses comuns, e agora sou eu outra vez, o autor, a complicar...... da maneira como SRO me tinha dito já antes a mim e o Trindade agora ali me reproduzia ipsis verbis, é que num caso destes é nação até onde for território em que encontres alguém que vai receber-te lá em casa dele se vocês são os dois da mesma origem matricial, da mesma barriga putativa, quer dizer, da mesma eanda dele, do mesmo clã, mesmo se a língua dele é diferente...... e estão-te lá a entender...... e a perceber o que é que te faz correr...... a regra geral é a mesma, para além da maneira diferenciada que for a da tua gente........ (CARVALHO, 2009, p. 400)

No trecho acima constatamos a importância atribuída ao pensamento sobre identidade. Compreendemos a partir da breve intervenção do narrador que Trindade e Severo compartilham a proposição de que as identidades são elaboradas e recriadas a partir das relações concretas que regem ou fundamentam suas vidas. Trindade e Severo nos fazem visualizar que há uma diversidade humana em tensão a ser percebida para a produção de compreensões mais alargadas. Não é apenas uma oposição entre brancos e negros, colonizados e colonizadores, usurpadores e usurpados, homens de ciência e iletrados que deverá ser levada em conta. Se essas grandes oposições nunca são irrelevantes, elas podem não ser sempre preponderantes. Há um conjunto diversificado de experiências do viver e do estar que produzem sentidos que ultrapassam a delimitação das grandes oposições. Nesse sentido a consciência esboçada pelas personagens em seus discursos vai ao encontro da consciência do antropólogo narrador. Seus discursos estão amalgamados ou "acamaradados" ou espelhados no desenrolar do enredo. A viagem e a busca das personagens são as do narrador ou autor, personas inseparáveis do artefato narrativo desenvolvido nos romances. E, no caso do discurso do Trindade, compreendemos que o exercício da palavra fulgurante não encontra barreiras de nenhuma ordem. Em Ruy Duarte de Carvalho podemos compreender a narrativa enquanto exercício do pensamento-ação necessário para a composição de si e do mundo a partir do lugar onde se vive e se compreende as possibilidades de produção da vida. 
Para reforçar a constatação de que há uma integração profunda entre as consciências de autor e personagens trazemos trecho de sua conferência intitulada "Figuras, figurões \& figurantes na cena democrática angolana - Papeis, marcações e desempenhos..." e realizada em Luanda em 2004:

Nunca me propus fazer análise política que não decorresse do uso das minhas ferramentas profissionais de antropólogo e que não se reportasse a problemas de sociedade e de cultura a que a antropologia social possa acrescentar algum esclarecimento. E no entanto, ou por isso mesmo, os anos que tenho passado a observar e a analisar as práticas, os comportamentos e as dinâmicas de resposta às incidências envolventes por parte dos pescadores da costa luandense, de outros sectores das populações da capital, de populações rurais do planalto central e de pastores e agro-pastores do nosso sudoeste, têm-me permitido apreender de alguma forma a maneira como esse sectores da sociedade angolana são situados e se situam em relação ao nosso processo político.

É isso que me tem conduzido a tratar, a produzir e a divulgar, de há mais de vinte anos a esta parte, questões que agora, finalmente, são reconhecidas como pertinentes. É o caso da questão das expressões colectivas, quer dizer, das identidades culturais parcelares que participam e intervêm na nossa cena política. Nunca deixei de desenvolver e de propor para debate, sempre que a oportunidade o facultava e permitia, questões ligadas a conceitos como o de nação, que finalmente parece oportuno e até rentável tratar agora entre nós. E isso desde uma altura em que a componente étnica do problema angolano, por exemplo, estava completamente arredada, para não dizer banida e interditada, das ideologias, dos discursos, das acções e das atitudes em presença e em disputa. (CARVALHO, 2008, p. 28)

A ficcionalização de um mundo misturado operada por Ruy Duarte de Carvalho nos faz atentar para a configuração de identidades coletivas parcelares e nos permite entender que elas não podem ser abafadas ou ignoradas num projeto de Estado. Talvez, Trindade possa ser apontado como simbolização máxima desta ideia. Sendo um negro visto como não-banto cujo oficio de cozinheiro lhe permitiu travessias por experiências contrastantes, Trindade teve que aprender a produzir sua existência a partir das relações disponíveis nos contextos pelos quais se conduziu ou para os quais foi conduzido. 


\section{Poesia em Os papeis do inglês}

No romance Os papéis do inglês podemos apreciar momentos em que a poesia da prosa clama por versos e o autor os compõe. Os capítulos possuem em sua abertura anotações extremamente subjetivas e poéticas que possuindo datas remeteriam ao diário de campo do autor-narrador-antropólogo. Vejamos:

\subsubsection{9}

A hesitação coloca-se ao nível da experiência. É ela que constitui o mais importante do material, do capital acumulado. Mas ela, a experiência, constitui-se a partir das referências. As do mundo e do tempo anteriores. E é a esse mundo anterior que a ordem das coisas, e da própria experiência, me impõe dar testemunho. Não viesse eu de fora e a experiência seria a da existência comum, não se revelaria como experiência, nem se revelaria sequer, estaria integrada na existência. E, assim, se me sentisse impelido a dar testemunho de alguma experiência, tratar-se-ia daquela que, fora da existência, me tivesse sido dado acometer. A experiência, assim, só faz sentido quando referida, à partida e à chegada, ao que lhe é exterior. Sem o antes não poderia ter tido lugar, sem o depois perderia o sentido. E a contradição maior reside no seguinte: tratando-se de uma experiência total, o seu saldo efectivo estaria em dar-lhe continuidade. E ela assim deixaria de o ser, transformar-se-ia em rotina, existência.

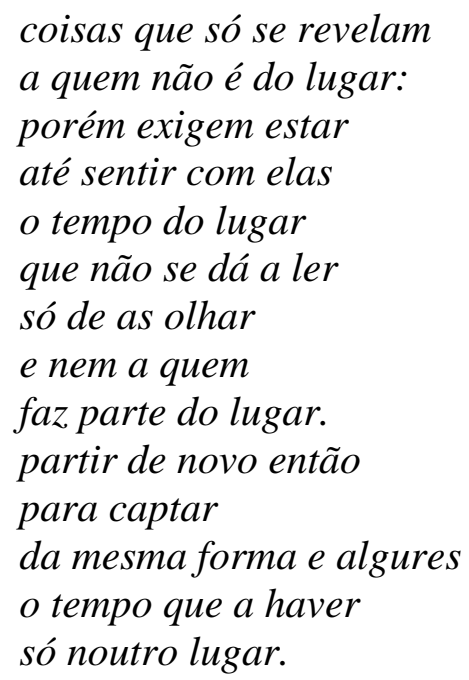

No excerto retirado do suposto diário de campo vemos a beleza do pensamento já bem expresso em prosa deslizar para a concentração do poema. O autor nos expõe a 
ideia de que há uma dialética entre experiência e existência. A experiência é constituída no deslocamento ou na viagem, portanto ela é contrária à existência dada pela permanência. Em algum momento o capital acumulado pela experiência deveria transformar-se em existência garantindo a esta experiência uma continuidade, mas aí a experiência dramaticamente anula-se, vira existência, ou seja, a permanência de um mesmo que não é capaz de transformação já que essa depende da experiência que depende da mobilidade. $\mathrm{O}$ algures é pulsão de vida para o poeta e para o antropólogo.

A viagem é um dos elementos que fundamentam a poética de Ruy Duarte de Carvalho. E n'Os papeis do inglês lemos uma obra que é canto aos viajantes e às suas viagens e às formulações textuais que delas resultam. Archibald Perkings, Severo, Jonas Trindade e também o narrador encontram na viagem a possibilidade da existência. As personagens possuem fome de espaço como escrevera Antonio Candido para se referir às obras da literatura brasileira do período romântico.

No ensaio “A propósito da narrativa contemporânea em Angola: notas sobre a noção de espaço em Luandino Vieira e Ruy Duarte de Carvalho”, Rita Chaves apontará que:

Em qualquer das modalidades cultivadas por esses autores, o trabalho de representação da realidade, compromisso constante da literatura, implica a mobilização de um sofisticado repertório de procedimentos que transforma o espaço em matriz de significados múltiplos (...) (CHAVES, p. 15, 2010)

Luandino Vieira encontrou no espaço do musseque de seu tempo, bairros pobres de Luanda, a força de uma prosa poética que visa à representação de um universo repleto de ambiguidades, um espaço de misturas entre o rural e o urbano, o oral e o letrado. Nós, os do mukuluso, escrito em 1967 durante a prisão do autor no Campo do Tarrafal, conforme nos informe Rita Chaves (1999), é uma das obras fundamentais da prosa angolana. Com o embate dos protagonistas no olho da guerra por libertação 
acompanhamos as divisões dramáticas de um espaço estruturado por tensões. Maninho e Mais-velho são dois irmãos que participam do conflito. Maninho, culturalmente identificado com o solo angolano lutará do lado dos colonizadores; Mais-velho, que não possui a mesma identificação que Maninho possui, lutará pela libertação de Angola. O romance é, certamente, exemplar na representação das urdiduras da vida nas composições das identidades e das escolhas.

Ruy Duarte de Carvalho encontra num outro espaço, nos caminhos do sul de Angola, outras realidades e outras personagens que comungam de problemas e tensões semelhantes. Não podemos nos afastar da constatação de Rita Chaves de que a "viagem não pode ser dissociada da experiência etnográfica" (CHAVES, p. 286), ou seja, do ofício de antropólogo. As viagens iniciáticas do antropólogo, como já vimos, inicialmente nas trilhas de um cinema pensado e conquistado para além do filme etnográfico, nos fazem conhecer não só identidades e espaços que não conhecíamos, como também as tramas imbricadas dos "processos de construções e desconstruções identitárias" (CARVALHO, 2000, p. 46)

Como escreveu Benedito Nunes ao tecer ponderações a respeito da viagem enquanto tema na obra de Guimarães Rosa, com a qual Carvalho dialoga profundamente: "Existir e viajar se confundem." (NUNES, 2009, p. 168) Na sequência, ao tecer comentários sobre Riobaldo, personagem de Grande sertão: veredas, afirmará que a "viagem redonda" ou "viagem-travessia", nas formulações do ensaísta, "constitui o saldo imponderável das ações, que a memória e a imaginação juntas recriam”. Ou seja, o resultado é a vivência que ganha sentido quando narrada, no contar-se a si e ao outro. A leitura de Guimarães Rosa efetuada por Benedito Nunes, no clássico $O$ dorso do tigre, se ajusta com perfeição às leituras que podemos realizar das obras de Ruy Duarte. 


\section{Vou lá visitar pastores: subjetividade e objetividade}

A prosa poética que desliza para a concentração do poema para contrapor experiência e existência nos remete a considerações em torno de Vou lá visitar pastores e a viagem ali empreendida.

O texto de Carvalho participa da necessidade de se pensar as identidades que constituem o Estado-Nação em Angola, ou dizendo melhor, os conflitos existentes na construção dessas identidades e os conflitos existentes entre essas identidades e as práticas do Estado. No instigante Vou lá visitar pastores em nenhum momento Ruy Duarte caracteriza os Kuvale como um grupo inteiramente distanciado da sociedade angolana. Compreender a identidade Kuvale é compreender a sua inserção na história da construção de Angola e é compreender a sua situação diante das políticas de Estado.

Considerada pela crítica uma obra de difícil classificação do ponto de vista do gênero, pode ser considerado um livro de passagem para aquilo que o próprio autor considerou ser o exercício de uma "meia-ficção" (CARVALHO, 2008, p. 19). Ainda mais formulado para o campo do ensaio e da pesquisa etnográfica, Vou lá visitar pastores possui elementos que alçam a obra para a atividade literária plena.

Como sugere Sonia Miceli (2011), será preciso atentar para o fato de que a obra dialoga com referenciais importantes do campo intelectual francês no qual se formara. A relação entre antropologia e literatura esteve presente na própria constituição do campo intelectual do país na leitura de James Clifford. Além disso, duas etnografias de peso merecem atenção pela repercussão que tiveram. Tristes Trópicos (1955) de LéviStrauss e A África fantasma (1934) de Michel Leiris são obras plenamente capazes de conquistar leitores para muito além do interesse pelos estudos que apresentam. São obras em que a vida vibra numa linguagem fulgurante que desperta imaginações. 
Em texto que compara as duas obras a partir do tema da viagem como pedra fundante do conhecimento antropológico, Fernanda Arêas Peixoto argumenta a respeito da obra de Lévi-Strauss:

Tristes Trópicos, como sabido, não é um simples relato da experiência brasileira de Lévi-Strauss (embora também o seja), nem um retrato do Brasil (ainda que o compreenda). Trata-se de um livro que parte do período brasileiro, mas que se descola dele, alçando outros voos. E é assim, como obra multifacetada, irredutível a uma única dimensão, que ela deve ser lida. (PEIXOTO, 2006, p. 288)

Vejamos um trecho da obra em edição traduzida por Rosa Freire d'Aguiar:

O Rio é mordido por sua baía até o coração; desembarca-se em pleno centro, como se a outra metade, nova Ys, já tivesse sido devorada pelas ondas. E em certo sentido é verdade, pois a primeira cidade, simples forte, ficava nessa ilhota rochosa que havia pouco o navio roçava e que continua a ter o nome do fundador: Villegaignon. Ando pela Avenida Rio Branco onde outrora erguiam-se as aldeias tupinambá, mas carrego no bolso Jean de Léry, breviário do etnólogo. (LÉVISTRAUSS, 1996, p. 77)

Embora o trecho escolhido seja curto, podemos notar certa melancolia no tom da narração marcada pelos verbos morder e devorar. Assim como a baía está mordida compreendemos que também já estão mordidas as aldeias que outrora se erguiam onde se abriu uma avenida. Mas o leva para um outro tempo o livro de Léry, Viagem feita à terra do Brasil, considerada uma obra-prima por Lévi-Strauss. Esse dado imediatamente nos remete a Ruy Duarte e seu Desmedida, já que o antropólogo angolano tem também a sua bagagem de livros que o transportam para cenas brasileiras remotas.

Acerca de A África Fantasma, considera Peixoto no mesmo texto que "escritor e etnólogo competem todo o tempo pelo domínio da narrativa e se revezam na descrição dos acontecimentos e estados de espírito". (РEIXOTO, 2006, p. 300) Passemos ao início de $A$ África fantasma traduzida por André Pinto Pacheco: 
19 de maio

Partida de Bordeaux às $17 \mathrm{~h} 50$. Os estivadores colocam um galhinho no Saint- Firmin para indicar que o trabalho foi concluído. Algumas putas dão adeus aos homens da tripulação com quem dormiram na noite precedente. Parece que quando o navio chegou vieram ao cais para convidar os homens a passar a noite com elas. Alguns trabalhadores negros do porto veem seus camaradas partir. Um deles, vestido de terno azulmarinho em "três camadas", paletó trespassado, cabeça coberta com um boné quadriculado à escocesa e calçado com verniz preto e camurça branca, está muito elegante.

20 de maio

Mar bonito, mas o navio balança um pouco. Oukhtomsky deitado.

Os outros mal ficam de pé, mas só o quinquagenário Larget está aprumado. Depois de Almoçar, vamos à proa do navio ver os dois porcos que são engordados para consumo.

Entre outros animais a bordo, estão gatos e um bodinho que a tripulação trouxe de Sassandra há dezoito meses. É uma mascote. De vez em quando fica excitado: o ferrão sai, vira a cabeça e morde o membro. Entre o Havre e Bordeaux, no mesmo estado, parece que jorrou em Moufle. Da outra vez, jorrou no próprio focinho.

No Havre vi um cachorrinho preto, mas ele não está mais aqui, foi esmagado em Bordeaux, quando estava prestes a desembarcar. (LEIRIS, 2007, p. 59)

Dois dias do longo diário de Leiris torna-se o suficiente para já identificarmos a influência de sua ligação com o surrealismo. O erotismo e a morte já aparecem nesse início garantindo um veio significativo da obra. O contar a viagem a partir de sua perspectiva colecionista e subjetiva está armada no texto desde o deflagrar do primeiro dia. De acordo com Fernanda Arêas Peixoto, em texto de apresentação à edição brasileira, podemos considerar a possibilidade de uma dupla etnografia oferecida por Leiris,

"etnografia das sociedades africanas e também do grupo de pesquisadores, quando revela, entre outras coisas, como a coleta de material, de objetos e de pinturas sagradas é feita a qualquer preço, algumas vezes mesmo através de pilhagem e corrupção." (PEIXOTO, 2007, p. 29) 
No artigo "Os antropólogos e suas linhagens", Mariza Peirano (1995) chama nossa atenção para algo definidor da ciência antropológica que é a busca da alteridade, cujo exercício de apreensão e compreensão é constituidor e propulsor desta disciplina científica. Muito embora os sistemas teóricos sejam fundamentais e devam constituir a base de formação para o cientista, é justamente no embate com o outro e com as categorias reais encontradas nos universos sob investigação que se poderá formular novas teorias ou reformular sistemas de compreensão já existentes. O que não quer dizer que está vedada a possibilidade de um antropólogo se tornar um eminente formulador teórico sem nunca ter saído a campo, mas apenas que o mesmo não pode se dar sem uma meticulosa reflexão assentada sobre dados coletados em algum momento e em algum lugar. Ou o pesquisador assentará suas reflexões sobre os frutos conseguidos de uma observação própria, ou recorrerá às observações obtidas através das leituras de monografias dos que puderam ir a campo, rearticulando-as e fecundando-as com novos olhares.

Ao permitir o encontro com o outro, que não pode jamais cair no engodo da mera descrição do exótico ou do curioso, do que chama a atenção do observador como dado aberrante, a ciência antropológica permite também a autorreflexão. Ainda que, o encontro com um universo humano extremamente distinto daquele do qual o pesquisador parte e onde se encontram as bases de sua identidade possa provocar nele um sensível alargamento da consciência de seu mundo, fazendo-o reverter para uma crítica dos entraves que vê em sua sociedade, há que se ter cautela. Isso também pode representar um problema a ser superado se a dose for demasiada e a monografia transformada num ensaio acusatório das debilidades do universo do pesquisador. Num outro e precioso sentido a autorreflexão pode representar a revisão dos instrumentos de aferição do antropólogo. E nesse sentido podemos compreender o projeto de escrita de Michel Leiris. Sua opção pela descrição minuciosa do cotidiano do grupo de pesquisa põe a descoberto práticas que demonstram que os caminhos da pesquisa nem sempre são aceitáveis do ponto de vista ético. Também podemos pensar com James Clifford em Leiris como símbolo ou referência de uma atitude que recusa visões totalizadoras que podem ser também redutoras do universo do outro. (CLIFFORD, 2002, p. 168) 
No trabalho de Ruy Duarte de Carvalho também encontraremos o contar da viagem com estratégias ficcionais que não obliteram o caráter antropológico da obra. Um aspecto da obra que nos parece interessante é a representação do diálogo indicado já pela nota introdutória. O autor dialoga com seu interlocutor e ao mesmo tempo podemos supor que esse diálogo se concretiza com o leitor. Vejamos a nota introdutória:

Em Agosto de 1997 fiz mais uma ronda pela Província do Namibe, sudoeste de Angola, onde desde 1992 mantenho um contato frequente com alguns pastores Kuvale. Estava previsto acompanhar-me, para se inteirar das terras e das gentes, e para olhar Angola a partir dali, um amigo meu, fixado em Londres e repórter da BBC. Acabei por fazer a viagem sem ele. Tardava e eu não podia adiar a partida. Admiti no entanto que talvez pudesse chegar ainda nos próximos dias, a tempo de alcançarme. Fui-lhe por isso deixando cassetes com a gravação do que contava dizer-lhe pelo caminho. Era a maneira de tentar ajudálo, mesmo assim, a alargar o contato com o que buscava. Não chegou a aparecer e mais tarde transcrevi essas cassetes. Divulgo agora os salvados, são a viagem do texto.

Verdadeiros ou falsos, o amigo e as cassetes, não importa, pois de qualquer forma está armada a retórica da obra. Ao dialogar com o amigo jornalista, Ruy Duarte arma também o diálogo com o leitor igualmente transformado em companheiro de viagem pelas paragens do sul de Angola. O texto passa a representar o diálogo entre o antropólogo e o jornalista. Estão, portanto, dispensados os artifícios do discurso científico convencional com os seus índices de distanciamento entre enunciador, matéria abordada e leitor (como plural impessoal, notas de rodapé, referências bibliográficas de acordo com os sistemas estabelecidos, tabelas, exposições teóricas, etc). Impõe-se o diálogo direto com o leitor que apreende as realidades observadas pelo autor por meio de uma prosa fluída e requintada. Um dado que deve ser mencionado é a referência à oralidade metaforizada pelas cassetes. Estaríamos diante de um texto que, supostamente, nascera oral e servira de base para a escrita. O que 
nos leva a pensar num dos temas caros para as literaturas africanas: a relação entre oralidade e escrita, este par de opostos, frequentemente harmonizados ou problematizados na literatura.

Para Edward Said, como já dissemos, o tema da viagem está associado a uma cultura de resistência. Os autores das antigas colônias e agora novos países se veem diante do imperativo de rever histórias, tradições, geografias, identidades, etc. É preciso que a palavra reconquistada recrie o que existe. Nesse sentido, a obra de Ruy Duarte de Carvalho revela-se uma expressão desta viagem para dentro nos termos de Said. Viagem que revela para olhos estrangeiros (e a referência a BBC é um símbolo nada casual) o que um sujeito de identidade angolana está considerando como propriamente angolano. As contradições que registra entre o modo de vida Kuvale e outros modos de vida em Angola são contradições imaginadas como angolanas.

Vale frisar que o relato inscrito em Vou lá visitar pastores, de Ruy Duarte de Carvalho, afasta-se consideravelmente dos relatos dos viajantes e exploradores analisados por Pratt. Talvez seja escusado assinalar que Carvalho escreve num contexto inteiramente distinto, seja quando consideramos os tempos históricos, seja quando consideramos o percurso de sua disciplina, a antropologia. Se os relatos de viagem de Pratt pertencem às configurações ideológicas que alimentaram os impérios, o texto de Carvalho insere-se na necessidade de se pensar as identidades que constituem o Estado-Nação em Angola, ou dizendo melhor, os conflitos existentes entre essas identidades e as práticas do Estado.

O que nos mobiliza a efetuarmos a comparação é justamente a possibilidade de associação entre as estratégias discursivas quando vistas em si mesmas. Tanto os relatos de viagem analisados por Pratt quanto trabalhos articulados de acordo com as 
propostas de uma antropologia crítica ou reflexiva podem ser associados pelas tentativas de representar o contato entre culturas privilegiando a interação, o diálogo, a reciprocidade ou a intersubjetividade. Contudo, os processos históricos delineiam contornos distintos a essas estratégias.

Vamos acompanhar um trecho que nos parece pertinente para refletirmos sobre o que assinalamos acima:

\begin{abstract}
Portanto, para já, os Mucubais são gatunos, e tudo se passa, assim, dentro dos parâmetros da distância, da abominação, do temor, do medo, da fascinação e do espanto. Algo entre a estigmatização, o desprezo e o fascínio do exótico. Por isso vão ainda assim servindo para ilustrar algumas festividades na capital da Província ou mesmo em Luanda e de vez em quando chega ordem para constituir um grupo folclórico de Mucubais que, accionados a vinho, se irão exibir perante públicos desdenhosos e complacentes. A televisão filma e é essa a imagem que os Kuvale candidamente permitem que a seu respeito seja divulgada por todo o país. (...) Isto de voluntarismos folclóricos passa a ser também uma violência quando, a coberto de necessidades de afirmação cultural e de cultos políticos que recorrem à tradição, se propõe a reabilitação de um passado quando o que afinal se exibe é antes a representação viciada a que o presente reduz esse passado. (CARVALHO, 2000, p.29)
\end{abstract}

Logo no início, na afirmação de que os mucubais roubam, o autor refere-se ao modo como esta população é vista pelo conjunto da sociedade urbanizada, que inclusive generaliza os povos pastoris, chamando-os a todos de mucubais. Termo que Ruy Duarte adota para registrar uma designação externa ao grupo. Assim percebemos que a identidade do grupo vai sendo composta pelo autor a partir do registro de diferentes pontos de vista. No entanto, desde o subtítulo do livro (exploração epistolar de um percurso angolano em território Kuvale (1992-1997)) vemos que o autor adota o termo que vai ao encontro da autodenominação. Embora o autor tenha estabelecido 
o diálogo com o leitor por meio de uma imagem poética, ou seja, remetendo o mesmo a uma possível oralidade geradora do texto que depois foi passado para a escrita, vemos que a composição não deixa de lado os conceitos por meio dos quais se opera a reflexão do antropólogo.

Falei-te atrás na cassete em que procurei esboçar uma possível colocação histórica para os Kuvale de hoje, daquilo a que chamo o "equívoco mandombe" e de forma sujeitos actuais que se reconhhecem e são reconhecidos como descendentes derectos dos sobas da Quipola e do Giraul , a quem era imputada essa identificação, recusam terminantemente esses seus antepassados tenham sido alguma vez "Mandombe". Eles reconhecem-se hoje, e são da mesma forma reconhecidos por todos, dentro e fora do grupo, como legítimos e inequívocos Kuvale pertencendo ao sub-grupo dos Vatyiheia, num quadro de autocolocação que por sua vez os articula aos Kuvale saídos dos "cubaes" da crônicas" (...) (CARVALHO, 2000, p. 78)

A estratégia de defender os Kuvale contra os preconceitos sociais ou contra a perspectiva de folclorização que parte do estado angolano nos coloca diante de um trabalho científico que, sem desprezar o rigor da análise, articula-se na defesa de posicionamentos políticos. Não se trata de revelar o que os Kuvale são ou devam ser, mas sim de apreender a constituição de identidades no interior de um estado fragmentado ou estruturado a partir de tensões.

Nesse aspecto, não estaríamos distantes das considerações levantados por Kwame Anthony Appiah (1992) em seu ensaio "Estados alterados". O intelectual ganês nos propõe que na maior parte dos estados africanos, tendo em vista a configuração das administrações coloniais e as relações estabelecidas com os chefes locais, será difícil conceber um estado cujo projeto não contemple essa problemática. Na visão de Appiah os indivíduos foram construindo associações identitárias, articuladas ou não 
em função de etnias, para as quais o Estado não funcionaria como um dirigente. (APPIAH, 1997, p. 238)

Nos três antropólogos, Lévi-Straus, Michel Leiris e Ruy Duarte de Carvalho vemos a viagem sendo reconstruída em relatos cadenciados entre a objetividade e a subjetividade e marcados por temas e estilos que remetem tanto à literatura quanto à antropologia desenvolvida por eles.

Tecer considerações em torno de Vou lá visitar pastores se torna relevante por se tratar de um livro de passagem do autor para sua obra romanesca. Embora a mistura de textualidades tenha sempre conduzido o autor, nesta narrativa a indefinição de gênero é logo percebida e ressaltada pela crítica.

Como indica Peirano (1995) não há um modo de ensinar pesquisa etnográfica senão por meio da leitura das obras clássicas no terreno da etnografia. Assim o conhecimento etnográfico insemina as teorias bem como os pesquisadores que irão a campo. Além da leitura dos clássicos, a biografia e opções teóricas do pesquisador, bem como os contextos de que participa com todos os imponderáveis da vida irão interferir na construção de sua experiência de campo. (PEIRANO, 1995, p. 22)

Tristes Trópicos e A África fantasma são clássicos que, talvez, já tenham passado a constituir uma linhagem de obras etnográficas confeccionadas com estratégias que não recusam a arte, antes preferem assumir a busca pela conjugação entre literatura e antropologia. Não poderíamos deixar de propor que Vou lá visitar pastores pode ser incluído nessa linhagem. Contudo, há que se verificar a posição diferenciada que possui em relação aos primeiros. Se neles encontramos olhares metropolitanos voltados para ex-colonizados ou colonizados, no livro de Carvalho nos 
deparamos com um diálogo entre sujeitos que definirão os rumos de uma comunidade nacional em processo. 


\section{Conclusões}

Como restituir a voz do outro? Podemos considerar que esta questão atravessa as obras e atravessou a vida de Ruy Duarte de Carvalho. A ideia, como vimos, definida como um programa em O camarada e a câmera - cinema e antropologia para além do filme etnográfico, ao longo de sua trajetória, foi recebendo distintos contornos. E ao mesmo tempo mantendo-se como um princípio fundamental na totalidade de sua produção sempre voltada para a reflexão sobre a construção das identidades em Angola.

A aproximação que fizemos em relação às suas reflexões em torno do cinema e, particularmente, as suas análises e descrições do trabalho de campo que envolveu a produção do filme Nelisita, nos possibilita a compreensão de uma série de temas e de proposições que acompanharam o seu exercício como escritor e antropólogo. Acompanhamos as reflexões antropológicas em relação ao filme pensado como produto artístico antropologicamente informado e que visa garantir a voz do outro. Compreendemos a junção que estabelece entre ficção e documento tendo como resultado uma obra coesa na qual a parte documental de entrega dos alimentos se integra a ficção, de modo que o espectador pode apreciar uma obra fílmica sem quebras. Confirmamos o seu interesse pela oralidade e o desejo de formalizá-la esteticamente. Compreendemos o seu compromisso político que o faz assumir-se como mediador entre culturas, pois do antropólogo em "situação nacional" exige-se tal compromisso em suas ponderações. Por fim, devemos ressaltar o exercício ético sendo desenhado nas negociações que conduzem à produção das imagens. Em seu relato lemos acerca da diferença de tratamento entre a produção dos documentários, nos quais a memória e os testemunhos estão privilegiados e a produção de Nelisita em que, sempre segundo os dados de seu relato, se estabeleceu uma remuneração proporcional a dos membros da equipe. Outro dado interessante que lemos em seu relato diz respeito à entrega de 
alimentos, vemos que esta não está relacionada a benemerências externas ao grupo, mas sim a negociações de troca compreendidas como pertencentes ao grupo. Esses relatos nos permitem ter contato com o modo pelo qual o antropólogo se relacionou com aquela comunidade. Isso nos possibilita a compreensão de que uma perspectiva que privilegie a interação ou a reciprocidade está plenamente vinculada às práticas e aos métodos de trabalho. Não são apenas paradigmas para fórmulas discursivas de exposição do contato quando o antropólogo volta de sua viagem e põe em prática o "escrever aqui" tendo já “estado lá” para relembrarmos os termos expressivos utilizados por Clifford Geertz. Por tudo isso, "O caso em situação" pode ser considerado um relato exemplar.

Em relação ao tema da oralidade cabe frisar que, em Nelisita, as fontes escritas elaboradas pelo Pe. Carlos Esterman, que não são negadas como legado cultural, constituem a referência para a construção do argumento do filme. As estórias registradas por Esterman não são tratadas como um resgate de origens, mas como uma possibilidade de pensar o contemporâneo do momento em que são reelaboradas como argumento e dramatizadas pelo grupo. Como diria a consciência partilhada do narrador de Como se o mundo não tivesse leste com o João Carlos natural do Chinguar, no Bié, “o homem é onde está". O cineasta promove uma relação viva com os textos. As estórias rearticuladas ganham voz lumuíla na medida em que elas dialogam com os problemas da opressão e da falta de recursos vividos pelo grupo com o qual Ruy Duarte trabalhava naquele momento, entre o final da década de setenta e início da década de oitenta. Assim, também podemos ver que nos discursos de Severo e Trindade, a oralidade representada pelo autor em seus livros não recusa a política ou as ideias elaboradas a partir das percepções do lugar e do tempo em que se vive.

A trilogia Os filhos de Próspero nos coloca diante de um universo fracionado em inúmeras tensões. Um mundo misturado para evocarmos o texto de Davi Arrigucci. A 
experiência dos sujeitos que habitam nesse universo é constituída a partir de ambiguidades que os tornam figuras desencaixadas e à mercê da errância. No entanto, compreendemos em nossa leitura das personagens Archibal Perkings, Severo e Trindade que a errância os leva a consciência de si e no caso de Severo e Trindade essa consciência formada sobre si é projetada como discurso narrativo. Navegar é preciso e o narrar compõe os sentidos da navegação.

Vemos que esse universo dialoga com aquele composto por Próspero em sua ilha na bela peça de Shakespeare, A tempestade. Utilizando o expediente da magia Próspero consegue trazer para sua ilha uma tripulação que ficará perdida no território desconhecido. Trata-se de um estratagema para que possa se vingar de seu irmão que usurpara seu trono e que se encontrava entre os homens do navio. Evocar esses elementos da peça nos faz pensar em Próspero como símbolo dos impérios e dos imperialismos capazes de instituir trajetórias, usurpar caminhos, extrair pessoas de seus lugares, interferir na constituição de suas identidades, aprisioná-las por distintos expedientes e nesse caso, é necessário lembrar que a língua é um desses expedientes utilizados por Próspero. A partir do momento em que Próspero opera suas interferências e muda as rotas, não será mais possível o retorno a ordem anterior ainda que Próspero abdique de sua magia ou de sua potência de escritor. As rotas interrompidas não podem ser mais formuladas nos sentidos que possuíam antes da interrupção. Elas só poderão ser recriadas em novos sentidos.

Os filhos de Próspero, ou seja, o mundo por ele criado está à procura de seus caminhos. Ruy Duarte de Carvalho ao refletir sobre os processos de construção das identidades, seja por meio de seu projeto estético ou sua poética, seja por meio de seus trabalhos acadêmicos ou textos de intervenção, sai em busca talvez não das respostas, 
mas da forma justa de colocação das questões. Daí a construção de uma prosa que atravessa variados gêneros e se compõe como uma miríade de saberes.

A leitura de Os papeis do inglês, As paisagens propícias e A terceira metade nos colocam diante de um projeto estético e político de grande envergadura. Vemos que o autor não ignora as questões de cor, mas também não as essencializa. Muito embora a trilogia possa e deva ser vista em conjunto, pois são vários os fios que as conecta; os livros também podem ser lidos como obras individuais, pois há eixos ou perspectivas diferenciados em cada um deles.

A demanda por papeis, ou seja, fontes documentais, que teriam pertencido ao obscuro inglês do primeiro romance, serve de motivação ou de pretexto para que o narrador empreenda suas viagens em busca de papeis e autores. A tal busca do narrador que atravessa dois livros transforma-se em busca pelas cassetes que conteriam rezas gravadas por Trindade, tio de Severo do segundo romance. Vemos que a busca por fontes escritas é transformada em busca por fontes orais. No entanto o oral encontrado em Trindade pode ser compreendido como um discurso em que a palavra assume múltiplas dimensões. A palavra ou o texto imaginado como oral é, na verdade, uma narrativa em que o narrador como um poeta-sábio recompõe seus espaços, suas trajetórias e a si mesmo. De certo modo, poderíamos evocar o filme Nelisita. A estratégia de Ruy Duarte de Carvalho ao compor o discurso de Trindade é pautada pelo “dizer” a si e aos outros o que se é a partir do que se compreende do lugar onde se está. O oral é formalizado na narrativa como o vivo, o comunicante, o que não pode renunciar o presente. A palavra ou o conhecimento que nos é exposto por Trindade não é o de uma África a ser sondada em seus interiores ocultos, rurais e iletrados e sim a palavra e o conhecimento gerados com as aprendizagens de seus deslocamentos formativos, com os diálogos com seu sobrinho Severo ou com os doutores e 
estrangeiros e finalmente, com o que sonhou e projetou a partir do exercício de sua compreensão.

A análise da produção textual de Ruy Duarte de Carvalho nos coloca diante de um autor com um potencial enorme de diálogo com outras textualidades e com outras realidades socioculturais, para além de Angola e para além do continente africano. Procuramos destacar alguns diálogos fundamentais como o empreendido com a obra de Guimarães Rosa, fonte em que o autor se inspira para o caminho que escolhe no tratamento da oralidade. Embora recuse a criação linguística nos níveis prosódico, fônico, lexical e sintático, pois isso é para quem nasce "ensinado" como nos diz, encontra a oralidade como narração primordial do contador que necessita lançar a sua voz. Voz que se adensa a partir da compreensão do lugar ou do contexto sociopolítico do qual emerge.

Sua obra, marcada pela erudição, constitui um verdadeiro e permanente convite à leitura. $\mathrm{O}$ pesquisador viajante representado nos textos leva sempre algum livro em sua bagagem. Assim vemos o narrador de Os papeis do inglês entregando um livro de Michel Leiris à outra personagem. Em As paisagens propícias o narrador travará um diálogo com Viagens na Cimbebásia do padre Duparquet, reunião de textos de um missionário que também frequentou as propícias paisagens frequentadas por Ruy Duarte. Logo nas primeiras páginas de Desmedida saberemos que esse amante das letras deseja conhecer os espaços representados nas páginas de Guimarães Rosa e Euclydes da Cunha. E nessa viagem outros livros o acompanharão ou serão encontrados durante o percurso. E, finalmente, o narrador Trindade, a quem aprendemos a ouvir, transformará As aventuras de Huckleberry Finn, do também aventureiro Mark Twain, em um grande companheiro. Os livros e os autores citados são apenas algumas das escolhas que podemos fazer para compreender a prosa definida pelo próprio autor como uma "meia- 
ficção-erudito-poético-viajeira". A formulação do autor nos revela um juízo crítico bastante agudo e, talvez, devêssemos dizer definitivo. Nessa formulação encontramos a junção de saberes e discursos como um exercício de compreensão do mundo com ciência e arte. Encontramos a viagem como necessidade da interlocução, do encontro e do acúmulo de experiências gerado pelo deslocamento. E encontramos a poesia como uma força permanente na busca pela voz do poeta-sábio no domínio das erudições que estão em toda parte e o eleva para o todo.

A erudição do autor jamais poderá ser tomada como virtuosismo intelectual, antes deverá ser compreendida nos moldes em que ela é representada na tessitura dos enredos. As obras citadas estão conectadas ao autor de um modo visceral. Elas simbolizam a viagem e o conhecimento como intrinsecamente associados. A partir delas o autor confecciona a sua ode aos viajantes, mesmo quando seus comportamentos e ideias estão fora do que poderia ser tido por modelar e, nesse ponto, nada melhor do que evocar Henrique Galvão ou Céline de Os papeis do inglês, reunidos no que chamamos o coro dos descomportados. Não é possível ignorar que eles participam como figuras numa montagem que remete ao quanto a vida vista nos seus processos de construção de identidades é sempre mais complexa do que gostaríamos. Nesse sentido, a montagem se torna representativa não só de Archibald Perkings, personagem que habita Os papeis do inglês, como também de Severo e Trindade. São homens de fronteira, personagens que representam um mundo misturado ou o "homem dos avessos" para retomarmos a expressão de Antonio Candido ao encontrar as ambiguidades estruturantes da poética de Guimarães Rosa em Grande Sertão: Veredas. Homens tensionados entre o rural e o urbano, o branco e o negro, o passado e o presente. E a tensão que privilegiamos é a compreendida entre o oral e o escrito. 
A erudição do autor também poderá ser compreendida pelo seu caráter formador. O narrador mostra-se sempre como um leitor, um amante das letras. $\mathrm{O}$ conhecimento acumulado a partir dos deslocamentos, dos territórios e dos encontros (não esquecendo sua definição de antropologia como uma ciência de relações humanas), não dispensa o conhecimento obtido pela leitura. E com ambos a relação é sempre viva. A conexão profunda com os textos partilha os gestos de negação e aceitação. Na leitura de As paisagens propícias ressaltamos que o autor endossa informações do missionário Duparquet e desautoriza outras. Ainda que a ideologia colonial se apresente nos textos e seja sempre preciso desvendar as suas marcas discursivas, os textos dos viajantes não deixarão de representar também a possibilidade do encontro com a informação ou o dado que auxilia nas leituras do passado e nas configurações teóricas do presente. Nisso, em boa medida, se expressa a consciência do antropólogo que transforma a releitura dos dados apreendidos pela descrição de outros viajantes em um de seus métodos de análise e de elaboração de conceitos.

A leitura que realizamos dos livros reunidos nesse trabalho, tendo sob foco privilegiado a trilogia Os filhos de Próspero nos permitiu entender alguns dos caminhos trilhados por uma prosa de generosidade plena e rigor incontestável. Marcada pela permanência da poesia, a prosa de Ruy Duarte de Carvalho encontrou na mistura de saberes escritos e orais e na viagem compreendida como busca formadora elementos estruturantes. 


\section{Bibliografia:}

\section{Corpus literário:}

CARVALHO, Ruy Duarte. O camarada e a câmera: cinema e antropologia para além do filme etnográfico. Luanda: INALD, 1984. . As paisagens propícias. Lisboa: Cotovia, 2005. . Os papeis do inglês. São Paulo: Companhia das Letras, 2007. . A terceira metade. Lisboa: Edições Cotovia, 2009.

\section{Bibliografia de Ruy Duarte de Carvalho:}

CARVALHO, Ruy Duarte. Actas da Maianga. Lisboa: Cotovia, 2003. Ana a manda: os filhos da rede. Lisboa: IICT, 1989. Aviso à navegação: olhar sucinto e preliminar sobre os pastores Kuvale da província do Namibe com um relance sobre as outras sociedades pastoris do sudoeste de Angola. Luanda: INALD, 1997.

A câmara, a escrita e a coisa dita... fitas, textos, palestras. Lisboa: Cotovia, 2008.

. O camarada e a câmera: cinema e antropologia para além do filme etnográfico. Luanda: INALD, 1984.

. Chão de oferta. Luanda: Culturang, 1972.

. Como se o mundo não tivesse leste. Luanda: UEA, 1977.

. A decisão da idade: poemas. Lisboa: Sá da Costa; Luanda: UEA, 1976.

. Desmedida: Luanda - São Paulo - São Francisco e volta. Crônicas do Brasil. Lisboa: Cotovia, 2006. . Exercícios de crueldade. Lisboa: EETC, 1978. . Hábito da terra. Luanda: UEA, 1988.

. Os Kuvale: na história, nas guerras e nas crises: artigos e comunicações: 1994-2001. Luanda: Nzila, 2002.

. Lavra paralela. Luanda: UEA, 1987.

. Lavra: poesia reunida 1970/2000. Lisboa: Cotovia, 2005.

. Lavra reiterada. Luanda: Nzila, 2000. 
. Memória de tanta guerra. Lisboa: Veja, 1992.

. Observação direta. Lisboa: Cotovia, 2000.

- Ondula savana branca. Lisboa: Sá da Costa; Luanda: UEA, 1982.

. Ordem de esquecimento. Lisboa: Quetzal, 1997.

. As paisagens propícias. Lisboa: Cotovia, 2005.

. Os papeis do inglês. Lisboa: Cotovia, 2000.

. Sinais misteriosos... já se vê... 7 textos e 10 desenhos de

inspiração mumuíla. Lisboa: Edições 70; Luanda: UEA, 1979.

. A terceira metade. Lisboa: Cotovia, 2009.

. Vou lá visitar pastores. Lisboa: Cotovia, 1999.

\section{Bibliografia crítica de Ruy Duarte de Carvalho:}

Artigos e ensaios:

ALMEIDA, Miguel Vale. “Antropologia e literatura: a propósito e por causa de Ruy Duarte de Carvalho”. In: Jornal do Ciclo Ruy Duarte de Carvalho, Centro Cultural de Belém, fev/2008.

CARDOSO, Claudia Fabiana de Oliveira; PADILHA, Laura Cavalcante. "Veredas ao sul: a escrita ficcional de Ruy Duarte de Carvalho". In: Ipotesi, Juiz de Fora, vl. 14, no. 2, jul/dez 2010, p.159-167. Disponível em : www.ufjf.br/revistaipotesi

CARDOSO, Claudia Fabiana de Oliveira. “A jornada do herói em dois poemas de Ruy Duarte de Carvalho”. In: Mulemba, Rio de Janeiro, no. 4, jul/2011, Disponível em: setorlitafrica.letras.ufrj.br/mulemba.

CHAVES, Rita. "Ruy Duarte de Carvalho: a palavra entre as decisões motivadas. In: Setepalcos, Coimbra, Portugal, no. 5, julho/2006, p. 19-24.

. “A propósito da narrativa contemporânea em Angola: notas sobre a noção de espaço em Luandino Vieira e Ruy Duarte de Carvalho”. In: África, escritas literárias: Angola, Cabo Verde, Guiné-Bissau, Moçambique, São Tomé e Príncipe. SECCO, Carmen Tindó; SALGADO, Maria Teresa e JORGE, Sílvio Renato. Rio de Janeiro: Editora UFRJ; Angola: UEA, 2010, p. 13-21. 
. “A poética de Ruy Duarte de Carvalho: memória e cumplicidade”. In:

Angola e Moçambique: experiência colonial e territórios literários. Cotia: Ateliê Editorial, 2005, p. 121-136.

. "Modos de ver e escrever o mundo em Ruy Duarte de Carvalho". In: CHAVES, Rita; MACÊDO, Tania; VECCHIA, Rejane. A kinda e a misanga: encontros com a literatura angolana. São Paulo: Cultura Acadêmica; Luanda: Nizla, 2007, p. 335-347.

. "Ruy Duarte de Carvalho: a educação pela terra" In: CHAVES, Rita; MACÊDO, Tania; VECCHIA, Rejane. A kinda e a misanga: encontros com a literatura angolana. São Paulo: Cultura Acadêmica; Luanda: Nizla, 2007, p. 109-116.

. "Ruy Duarte de Carvalho: tradição e rupturas na escrita de Angola".

In: CHAVES, Rita; MACÊDO, Tania. Literatura de língua portuguesa: marcos e marcas - Angola. São Paulo: Arte \& Ciência, 2007, p. 135-151.

. "Ruy Duarte de Carvalho: escritas de viagem". In: Revista Cerrados, vl. 19, no. 30, 2010, p. 281-293. Disponível em: www.revistacerrados.com.br

CROSARIOL, Isabelita Maria. “O dizer da guerra na poética de Ruy Duarte de Carvalho". In: Darandina revista eletrônica - Programa de Pós-graduação em Letras/UFJF, vl. 2, no. 2, jun/2009. Disponível em: www.ufjf.br/darandina

EWALD, Felipe Grüne. “Arte e conhecimento em Os papeis do inglês, de Ruy Duarte de Carvalho". In: Abril - Revista do núcleo de estudos de literatura portuguesa e africana da Uff, vl. 4, no. 7, novembro/2011, p. 65-78. Disponível em: www.uff.br/revistaabril

FONSECA, Maria Nazareth Soares. "Impurezas e hibridações: textos em transformação”. In: Aletria, vl. 9, dez/2002. Disponível em www.letras.ufmg.br/poslit

IWAI, Marcia. “Os papeis do inglês, de Ruy Duarte de Carvalho e a desconstrução do romance de aventura”. In: Aurora (revista eletrônica), no. 6, 2009, p. 36-49. Disponível em: www.pucsp.br/revistaaurora

LEITE, Ana Mafalda. "Radicação, Reescrita, Recomposição: Ruy Duarte de Carvalho". In: Oralidades \& escritas nas literaturas africanas. Lisboa: Edições Colibri, 1998, p. 131-142.

MORAES, Anita. "Ficção e etnografia: o problema da representação em Os papeis do inglês, de Ruy Duarte de Carvalho, e Nove noites, de Bernardo Carvalho.” In: Revista Via Atlântica, São Paulo, no. 21, 2012, p. 155-172. 
NICOLAU, Tereza. "A utopia da identidade no cinema de Ruy Duarte de Carvalho”. In: Setepalcos, Coimbra, Portugal, no. 5, julho/2006, p.44-47.

OLIVEIRA, Jurema José. “A poesia contemporânea nos países africanos de língua portuguesa”. Revista Augustus, Rio de Janeiro, vl. 14, no. 27, fev/2009, p. 21-27. Disponível em: www.unisuam.edu.br/augustus

ORNELLAS, Sandro. "Ruy Duarte de Carvalho em transumância pelos discursos. In: Eutomia Revista online de literatura e linguística. Ano II, no. 1, p. 191211. Disponível em: www.revistaeutomia.com.br

PADILHA, Laura Cavalcante. "Reconversões". In: Revista Via Atlântica, São Paulo, no. 1, mar/1997, p. 142-152.

QUINTAIS, Luís. "O olhar do rinoceronte - ou o Ruy como o vejo". In: Setepalcos, Coimbra, Portugal, no. 5, julho/2006, p. 16-19.

SILVEIRA, Regina da Costa; TAROUCO, Elisângela. "Os papeis do inglês e $O$ velo d'oiro: diversidades do real". In: Letras hoje, Porto Alegre, vl. 43, no. 4, outdez/2008, p. 73-77. Disponível em: revistaseletronicas.pucrs.br

SILVESTRE, Osvaldo Manuel. "Notas sobre paisagem e tempo em Ruy Duarte de Carvalho. In: Setepalcos, Coimbra, Portugal, no. 5, julho/2006, p. 25-29.

TAVARES, Ana Paula. "Desmedida Luanda - São Paulo - São Francisco e volta”. In: Navegações, Porto Alegre, vl. 1, no. 1, mar/2008, p. 71-73. Disponível em: revistaseletronicas.pucrs.br

\section{Teses e Dissertações}

ARAÚJO, Maria Manuela Jales Camposana. Textos afro-americanos e textos africanos: Di-cursus do Eu ao espelho repartido da diáspora discursiva moderna. Tese de doutorado. Universidade de Lisboa, 2008.

BASTOS, Nancy Mary de Castro. A teia de sonhos da memória, voz e letra: uma ordeNação whitmaniana. Dissertação de mestrado. Universidade Federal do Rio Grande do Norte, 2001.

CHAVES, Rita. Narrativa e espaço: Angola, Moçambique e alguns ecos do império. Trabalho de Livre-docência. Universidade de São Paulo, São Paulo, 2012.

CROSARIOL, Isabelita Maria. Impérios desmitificados: Ruy Duarte de Carvalho e o passado colonial reescrito. Dissertação de mestrado. Pontifícia Universidade Católica do Rio de Janeiro, Rio de Janeiro, 2009. 
MARQUES, Diego Ferreira. Paisagens de papel, culturas da reinvenção: literatura, antropologia e colonialidade na narrativa de Ruy Duarte de Carvalho. Dissertação de mestrado. Universidade Federal Fluminense, Niterói, 2007.

MICELI, Sonia. Contar para vivê-lo, viver para cumpri-lo: autocolocação e construção do livro na trilogia ficcional de Ruy Duarte de Carvalho. Dissertação de mestrado. Universidade de Lisboa, 2011.

NASCIMENTO, Márcia dos Santos do. Duas margens do Atlântico: Brasil e Angola: paisagem e escrita no percurso poético de Edimilson de Almeida Pereira e Ruy Duarte de Carvalho. Tese de doutorado. Universidade Federal Fluminense, Niterói, 2010.

OLÍVIO, Lidiane. O narrador, o espaço e a digestão dos casos: uma leitura de Como se o mundo não tivesse leste, de Ruy Duarte de Carvalho. Dissertação de mestrado. Universidade de São Paulo, São Paulo, 2013.

PAULA, Gabriel Jorge de Quadros. O caçador de pipas $e$ Os papeis do inglês: as instáveis fronteiras entre o romance autobiográfico e a autoficção. Dissertação de mestrado. Universidade Federal do Rio Grande, 2011.

PEREIRA, Prisca Rita Agustoni de Almeida. O Atlântico em movimento: travessia, trânsito e transferência de signos entre África e Brasil na poesia contemporânea em língua portuguesa. Tese de doutorado. Pontifícia Universidade Católica de Minas Gerais, Belo Horizonte, 2007.

SANTOS, Carla Cristina Bianchi. O espaço nas obras Hábito da terra de Ruy Duarte de Carvalho e A educação pela pedra de João Cabral de Melo Neto. Dissertação de mestrado. Universidade de São Paulo, São Paulo, 2001.

SILVA, Renata Flávia. Quatro passeios pelos bosques da ficção angolana. Tese de doutorado. Universidade Federal do Rio de Janeiro, Rio de Janeiro, 2008.

SOUZA, Marli Paz. Do sul de Angola ao Nordeste brasileiro: um itinerário poético. Tese de doutorado. Universidade Federal da Paraíba, João Pessoa, 2007.

\section{Bibliografia específica: antropologia:}

ALMEIDA, Miguel Vale; BASTOS, Cristina; FELDMAN-BIANCO, Bela (orgs). Trânsitos coloniais: diálogos críticos luso-brasileiros. Campinas: Editora da Unicamp, 2007. 
CAVIGNAC, Julie Antoinette; GROSSI, Miriam Pillar; MOTTA, Antonio. Antropologia francesa no século XX. Recife: Fundação Joaquim Nabuco, Editora Massangana, 2006.

CLIFFORD, James. A experiência etnográfica: antropologia e literatura no século XX. Rio de Janeiro: UFRJ, 2002.

DURHAM, Eunice Ribeiro. "Uma nova visão da antropologia”. In: DURHAM, Eunice Ribeiro. Malinowski. São Paulo: Editora Ática, 1986.

GEERTZ, Clifford. A interpretação das culturas. Rio de Janeiro: LTC, 1989. Obras e vidas: antropólogo como autor. Rio de Janeiro: Ed. UFRJ, 2002. O saber local. Petrópolis: Vozes, 1997.

GOIFMAN, Kiko. Valetes em slow motion - a morte do tempo na prisão: imagens e textos. Campinas: Editora da Unicamp, 1998.

KUPER, Adam. Antropólogos e Antropologia. Rio de Janeiro: F. Alves, 1978.

LARAIA, Roque de Barros. "Ética e antropologia - algumas questões". In: Série Antropologia, Universidade de Brasília, no. 57, 1993, p. 1-13.

LEIRIS, Michel. A África fantasma. São Paulo: Cosac Naify, 2007. . A idade viril. São Paulo, Cosac Naify, 2003. . Espelho da tauromaquia. São Paulo, Cosac Naify, 2001. . "O etnógrafo perante o colonialismo". In: SANCHES, Manuela

Ribeiro. Malhas que os impérios tecem. Textos anticoloniais, contextos pós-coloniais. Lisboa: Edições 70, 2011.

LEVI-STRAUSS, Claude. Tristes trópicos. São Paulo: Companhia das Letras, 2005.

MALINOWSKI, Bronislaw. Argonautas do Pacífico Ocidental: um relato do empreendimento e da aventura dos nativos nos arquipélagos da Nova Guiné Melanésia. São Paulo: Abril Cultural, 1984. . Um diário no sentido estrito do termo. Rio de Janeiro: Record, 1997.

MERCIER, Paul. História da Antropologia. São Paulo, Editora Moraes, [19--].

MAUSS, Marcel. Sociologia e Antropologia. São Paulo: Cosac Naify, 2003.

MOTTA, Antonio. “A África fantasma de Michel Leiris”. In: CAVIGNAC, Julie Antoinette; GROSSI, Miriam Pillar; MOTTA, Antonio. Antropologia francesa no século XX. Recife: Fundação Joaquim Nabuco, Editora Massangana, 2006, p. 261-275. 
OLIVEIRA, Roberto Cardoo. "O saber, a ética e a ação social”. In: Manuscrito. Revista Internacional de Filosofia, vol XIII, no. 2, 1990, p.7-22.

PEIRANO, Mariza. A favor da etnografia. Rio de Janeiro, Relume-Dumará, 1995.

PEIXOTO, Fernanda Arêas; PONTES, Heloisa; SCHWARCZ, Lilia Moritz. Antropologias, histórias, experiências. Belo Horizonte: Editora da UFMG, 2004.

PEIXOTO, Fernanda Arêas. "A viagem como vocação - antropologia e literatura na obra de Michel Leiris”. In LEIRIS, Michel. A África fantasma. São Paulo: Cosac Naify, 2007, p.19-33.

PEIXOTO, Fernanda Arêas. "O nativo e o narrativo - os trópicos de LéviStrauss e a África de Michel Leiris". In: CAVIGNAC, Julie Antoinette; GROSSI, Miriam Pillar; MOTTA, Antonio. Antropologia francesa no século XX. Recife: Fundação Joaquim Nabuco, Editora Massangana, 2006, p. 287-310.

PORTELLI, Alessandro. “O sentimentalismo: A cabana do pai Tomás (Harriet Beecher Stowe, 1852)". In: MORETTI, Franco (org.) O Romance, 1: a cultura do romance. Trad. Denise Bottmann. São Paulo: Cosac Naify, 2009.

PRITCHARD, Evans. Os Nuer. São Paulo: Perspectiva, 2002.

ROUANET, Sérgio. “Antropologia e ética”. In: Mal estar na modernidade. São Paulo: Companhia das Letras, 1993, p. 255-293.

SILVA, Vagner Gonçalves. O antropólogo e sua magia. São Paulo: Edusp, 2006.

. "Entre a poesia e o raio x. Uma introdução à tendência pós-moderna na antropologia”. In GUINSBURG, J.; BARBOSA, Ana Mãe (orgs). Pós-modernismo. São Paulo: Perspectiva, 2005, pp. 145-158.

. "Religiões afro-brasileiras. Construção e legitimação de um campo do saber acadêmico (1900-1960)”. In Revista USP, setembro / outubro / novembro 2002, n. 55 , p. 83-111.

SZTUTMAN, Renato. "Jean Rouch: um antropólogo-cineasta". In: NOVAES, Sylvia Caiuby [et al.] (orgs). Escrituras da imagem. São Paulo: Fapesp: Edusp, 2004, p. 49-62. 


\section{Bibliografia Geral:}

ABDALA JR., Benjamin. Literatura história e política: literaturas de língua portuguesa no século XX. São Paulo: Ática, 2007. . De vôos e ilhas. São Paulo, Ateliê, 2003. . "Panorama histórico da literatura angolana". In: CHAVES, Rita; MACEDO, Tânia (orgs.). Marcas da diferença: as literaturas africanas de língua portuguesa. São Paulo: Alameda, 2006, p. 211-216.

ADORNO, Theodor. "O ensaio como forma". In Cohn, Gabriel (org.) Theodor W. Adorno. Sociologia. São Paulo: Ática, 1986, p.167-187.

APPIAH, Kwame Anthony. Na casa de meu pai: a África na filosofia da cultura. Rio de Janeiro: Contraponto, 1997.

ARRIGUCCI JR., Davi. "O mundo misturado: romance e experiência em Guimarães Rosa”. Novos Estudos Cebrap, no. 40, novembro/1994, p. 7-29.

ASSIS JR., Antonio de. O segredo da morta: romance de costumes angolenses. Luanda: Maianga, 2004.

AUERBACH, Erich. Mimesis. A representação da realidade na literatura ocidental. 5 ${ }^{\text {a } . ~ E d . ~ S a ̃ o ~ P a u l o: ~ P e r s p e c t i v a, ~} 2004$.

BAKHTIN, Mikhail. Questões de Literatura e de estética: a teoria do romance. São Paulo: Ed. Unesp, 1998.

BARROS, Diana Luz Pessoa; FIORIN, José Luiz (orgs.) Dialogismo, Polifonia, Intertextualidade: em torno de Bakhtin. 2a. ed. São Paulo: Edusp, 2003.

BENJAMIM, Walter. Obras escolhidas. Vol. 1. São Paulo, Brasiliense, 1985.

BOSI, Alfredo. Dialética da colonização. São Paulo: Companhia das Letras, 1992.

CANDIDO, Antonio. A educação pela noite e outros ensaios. São Paulo: Ática, 1987. . O estudo analítico do poema. São Paulo: Humanitas, 1999. . Formação da Literatura Brasileira (momentos decisivos). São Paulo: Livraria Martins Editora, 1959. . (et al.) A personagem de ficção. São Paulo: Perspectiva, 2007. . Tese e antítese. São Paulo: Companhia Editora Nacional, 1964.

CARVALHO, Ruy Duarte. Ana a manda: os filhos da rede. Lisboa: Instituto de investigação científica tropical, 1989. 
A câmara, a escrita e a coisa dita... fitas, textos e palestras.

Lisboa: Edições Cotovia, 2008.

Como se o mundo não tivesse leste. Lisboa: Edições Cotovia, 2003.

, Como se o mundo não tivesse leste. Limiar: Porto/União dos escritores angolanos, 1980.

Desmedida: Luanda - São Paulo - São Francisco e volta. Rio de Janeiro: Língua Geral, 2010.

Lavra poesia reunida 1970/2000. Lisboa: Edições Cotovia, 2005. . Vou lá visitar pastores. Rio de Janeiro: Gryphus, 2000.

CASCUDO, Camara. Dicionário do folclore brasileiro. Rio de Janeiro: Edições de Ouro, s/data.

CHAUÍ, Marilena. Conformismo e resistência: aspectos da cultura popular no Brasil. São Paulo: Brasiliense, 1986.

CHAVES, Rita. A formação do romance angolano. Entre intenções e gestos. São Paulo: Via Atlântica, 1999.

Angola e Moçambique. Experiência colonial e territórios literários.

Cotia: Ateliê Editorial, 2005.

CHAVES, Rita; MACEDO, Tânia (orgs). Literaturas em movimento. Hibridismo cultural e exercício crítico. São Paulo: Arte e Ciência, 2003. Literaturas de língua portuguesa: marcos e marcas - Angola. São Paulo: Arte \& Ciência, 2007. . Marcas da diferença: as literaturas africanas de língua portuguesa. São Paulo: Alameda, 2006.

CHAVES, Rita; MACEDO, Tânia; SECCO, Carmem (orgs). Brasil / África: como se o mar fosse mentira. São Paulo: Editora da Unesp, 2006.

CHAVES, Rita; MACEDO, Tânia; VECCHIA, Rejane (orgs.) A kinda e a misanga: encontros brasileiros com a literatura angolana. São Paulo: Cultura Acadêmica / Luanda: Nizla, 2007.

CONRAD, Joseph. O coração das trevas. Tradução e introdução: Marcos Santarrita. Rio de Janeiro: Nova Franteira, 2013.

CUNHA, Euclydes. 14a . ed. Os Sertões. Rio de Janeiro: Livraria Francisco Alves, 1938. 
DAL FARRA, Maria Lúcia. O narrador ensimesmado. São Paulo: Editora Ática, 1978.

DUPARQUET, Padre Carlos. Viagens na Cimbebásia. Versão e Prefácio de Gastão de Sousa Dias. Luanda: Museu de Angola, 1953.

ERVEDOSA, Carlos. Roteiro da Literatura Angolana. Lisboa: Edições 70, 1979.

FANON, Frantz. Os condenados da terra. Juiz de Fora: Editora UFJF, 2005.

FERREIRA, Manuel. Literaturas Africanas de Expressão Portuguesa. São Paulo: Ática, 1987.

FORSTER, E. M. Aspectos do romance. Porto Alegre: Editora Globo, 1969.

HAMILTON, Russel. Literatura africana. Literatura necessária. I - Angola. Lisboa, Edições 70, 1975.

HERNANDEZ, Leila Leite. A África na sala de aula: visita à história contemporânea. São Paulo: Selo Negro, 2005.

KAYSER, Wolfgang. Análise e interpretação da obra literária. $5^{\mathrm{a}}$. ed. Vol. I e Vol. II. Coimbra: Coleção Stvdivm, 1970.

KRISTEVA, Julia. Introdução à Semanálise. 2a. ed. São Paulo: Perspectiva, 2005.

LARANJEIRA, Pires. Literaturas africanas de expressão portuguesa. Lisboa: Universidade Aberta, 1995.

LEITE, Ana Mafalda. Literaturas africanas e formulações pós-coloniais. Lisboa: Edições Colibri, 2003.

. Oralidades \& Escritas nas literaturas africanas. Lisboa: Edições Colibri, 1998.

LUKÁCS, Georg. A teoria do romance. São Paulo: Duas Cidades / Editora 34, 2000

MACEDO, Tânia. Angola e Brasil estudos comparados. São Paulo: Arte e Ciência, 2002.

Luanda, cidade e literatura. São Paulo: Editora Unesp; Luanda:

Nzila, 2008.

MARGARIDO, Alfredo, Estudos sobre literaturas das nações africanas de língua portuguesa. Lisboa: A regra do jogo, 1980.

MELVILLE, Herman. Moby Dick. Tradução e notas: Vera Sílvia Camargo Guarnieri São Paulo: Editora Landmark, 2012. 
MEMI, Albert. Retrato do colonizado precedido pelo retrato do colonizador. Rio de Janeiro: Paz e Terra, 1989.

MOISÉS, Massaud. Dicionário de termos literários. São Paulo: Cultrix, 1985.

MORAIS, Antonio. Grande Dicionário da Língua Portuguesa. 10ª ed. Lisboa: Editorial Confluência, 1954.

MOURÃO, Fernando A. Albuquerque. A sociedade angolana através da literatura. São Paulo: Ática, 1978.

NETO, João Cabral de Melo. Morte e vida Severina e outros poemas em voz alta. $4^{\mathrm{a}}$. Ed. Rio de Janeiro: Editora Sabiá, 1971.

NEVES, Alexandre Gomes. Camara Cascudo e Óscar Ribas: diálogos no Atlântico. Dissertação de mestrado. Universidade de São Paulo, São Paulo, 2008.

NITRINI, Sandra. Literatura Comparada. História, teoria e crítica. São Paulo: Edusp, 1997.

NOA, Francisco. "Literatura colonial em Moçambique: o paradigma submerso". In Via Atlântica, DLCV / FFLCH / USP / São Paulo, 1999, no. 3, p.58-68.

NUNES, Benedito. O dorso do tigre. São Paulo: Editora 34, 2009.

PADILHA, Laura Cavalcante. Entre voz e letra: o lugar da ancestralidade na ficção angolana do século XX. Niterói, EDUFF, 1995.

Novos pactos, outras ficções: ensaios sobre literaturas afro-lusobrasileiras. Porto Alegre: EDIPUCRS, 2002. . "Reconversões". In: Via Atlântica, DLCV/FFLCH/USP/ São Paulo, 1997, no. 1, p.142-152.

PRATT, Mary Louise. Os olhos do império: relatos de viagem e transculturação. Bauru: EDUSC, 1999.

ROSENFELD, Anatol. “Literatura e Personagem”. In: CANDIDO, Antonio (et al.). A personagem de ficção. São Paulo: Perspectiva, 2007, p. 9-49.

RIBAS, Oscar. Uanga (feitiço). 4ª Ed. Luanda: União dos escritores angolanos, 1985.

ROSA, João Guimarães. No Urubuquaquá, no Pinhém (Corpo de baile). 9ª . Ed. Rio de Janeiro: Nova Franteira, 2001. Versão digital.

SAID, Edward. Cultura e imperialismo. São Paulo: Companhia das Letras, 1995.

_. Orientalismo: o Oriente como invenção do Ocidente. São Paulo: Companhia das Letras, 1997. 
SALGADO, Maria Tereza; SEPÚLVEDA, Maria do Carmo (orgs). Letras em Laços: África Brasil. Rio de Janeiro: Editora Atlântica,2000.

SANTILLI, Maria Aparecida. Africanidade. São Paulo: Ática, 1985. . Paralelas e tangentes entre literaturas de língua portuguesa. São Paulo: Arte e ciência, 2003.

SILVA, Alberto da Costa. Um rio chamado Atlântico: a África no Brasil e o Brasil na África. Rio de Janeiro: Nova Franteira/UFRJ, 2003.

SOARES, Francisco. Notícia da literatura angolana. Lisboa: Imprensa Nacional - Casa da Moeda, 2001.

SOROMENHO, Fernando Monteiro Castro. Terra morta. Rio Tinto: União dos escritores angolanos, 1988.

TWAIN, Mark. As aventuras de Huckleberry Finn. Tradução: Rosaura Eichenberg. Porto Alegre: LPM, 2011.

WISNIK, José Miguel. "Recado da viagem”. In Sccripta Literatura, PUC, Belo Horizonte, v 2 - n. 3, 1998.

ZUMTHOR, Paul. Introdução à poesia oral. Belo Horizonte: Editora UFMG, 2010. 